\title{
On the production of staphylocoagulase by staphylococcus aureus
}

Citation for published version (APA):

Engels, W. (1981). On the production of staphylocoagulase by staphylococcus aureus. [Doctoral Thesis, Maastricht University]. Rijksuniversiteit Limburg. https://doi.org/10.26481/dis.19811218we

Document status and date:

Published: 01/01/1981

DOI:

10.26481/dis.19811218we

Document Version:

Publisher's PDF, also known as Version of record

\section{Please check the document version of this publication:}

- A submitted manuscript is the version of the article upon submission and before peer-review. There can be important differences between the submitted version and the official published version of record.

People interested in the research are advised to contact the author for the final version of the publication, or visit the DOI to the publisher's website.

- The final author version and the galley proof are versions of the publication after peer review.

- The final published version features the final layout of the paper including the volume, issue and page numbers.

Link to publication

\footnotetext{
General rights rights.

- You may freely distribute the URL identifying the publication in the public portal. please follow below link for the End User Agreement:

www.umlib.nl/taverne-license

Take down policy

If you believe that this document breaches copyright please contact us at:

repository@maastrichtuniversity.nl

providing details and we will investigate your claim.
}

Copyright and moral rights for the publications made accessible in the public portal are retained by the authors and/or other copyright owners and it is a condition of accessing publications that users recognise and abide by the legal requirements associated with these

- Users may download and print one copy of any publication from the public portal for the purpose of private study or research.

- You may not further distribute the material or use it for any profit-making activity or commercial gain

If the publication is distributed under the terms of Article $25 \mathrm{fa}$ of the Dutch Copyright Act, indicated by the "Taverne" license above, 


\title{
on the production of staphylocoagulase by staphylococcus aureus
}

\author{
PROEFSCHRIF T \\ ter verkrijging van de graad van \\ Doctor in de Geneeskunde aan de \\ Rijksuniversiteit Limburg te Maastricht, \\ op gezag van de Rector Magnificus \\ Prof.Dr. W.H.F.W. Wijnen, \\ volgens het besluit van het College van Dekanen \\ in het openbaar te verdedigen \\ in de Aula van de Universiteit \\ op viijdag, 18 december 1981 \\ des namiddags te 16.00 uUr
}

door

\section{willem engels}

geboren te Helmond in 1946 
PROMOTOR : Prof.Dr. C.P.A. van Boven

REFERENTEN: Prof.Dr. H.C. Hemker

Prof.Dr. D.W. Tempest

Prof.Dr. J. Verhoef

Dit proefschrift werd bewerkt in het laboratorium voor Medische Microbiologie van de Rijksuniversiteit Limburg, onder leiding van Prof.Dr. C.P.A. van Boven. 

The study of the growth of bacterial cultures does not constitute a specialized subject or a branch of research: it is the basic method of Microbiology.

Jacques Monod (1949)

Aan mijn ouders 
Manuscript : Mevr. F. Claus-Hahn

Tekeningen : Mevr. M.A.F. Kamps

Druk : B. Meerstad, afdeling Reprografie, Rijksuniversiteit Limburg 


\section{CONTENTS}

Voorwoord

Abbreviations

Chapter 1 Introduction

Chapter 2 Influence of cultivation conditions on the production of staphylocoagulase by Staphylococcus aureus 104. (J. Gen. Microbiol. (1978) 109: 237-243)

Chapter 3 Continuous culture studies on the production of staphylocoagulase by Staphylococcus aureus. (Antonie van Leeuwenhoek (1980) 46: 533-550)

Chapter 4 Secretion of staphylocoagulase by Staphylococcus aureus: the role of a cell-bound intermediate. (Antonie van Leeuwenhoek, accepted for publication)

Chapter 5 The competitive ability of spontaneous staphylocoagulase-negative mutants of Staphylococcus aureus 104 and NCTC 8178 with respect to growth of the parent strains in continuous culture. (Antonie van Leeuwenhoek, accepted for publication; in abstract form, Antonie van Leeuwenhoek 47: $90-91$ )

Chapter 6 Rapid and direct staphylocoagulase assay that uses a chromogenic substrate for identification of Staphylococcus aureus. (J. Clin. Microbiol. (1981) 13: 496-500)

Chapter 7 General discussion and Summary

Samenvatting 


\section{VOORWOORD}

Het verschijnen van dit proefschrift stelt mij in de gelegenheid allen te bedanken die hieraan een directe of indirecte bijdrage hebben geleverd. Zonder daarbij iemand tekort te willen doen, wil ik een aantal met name noemen.

Allereerst ben ik grote dank verschuldigd aan mijn ouders, die mij in staat hebben gesteld een universitaire opleiding te volgen. Hun voortdurende interesse is een belangrijke stimulans geweest voor mijn verdere ontwikkeling.

Prof.Dr. C.P.A. van Boven. Cees, ik ben je zeer erkentelijk voor de gelegenheid die je mij hebt geboden voor het uitvoeren van dit onderzoek. Ondanks je drukke facultaire werkzaamheden vond je steeds tijd om het onderzoek met grote interesse en $\mathrm{kritische}$ opmerkingen te begeleiden.

Prof.Dr. H.C. Hemker dank ik voor zijn initiatief tot het stafylocoagulase-onderzoek en de manier waarop hij mij heeft weten te enthousiasmeren voor dit curieuze eiwit.

Prof.Dr. D.W. Tempest. Dave, jouw ideeën over fenotypische variabiliteit van micro-organismen hebben mede de basis gevormd voor dit proefschrift. Voor de wijze waarop je dit proefschrift aan je kritiek hebt onderworpen, ben ik je zeer erkentelijk.

Prof.Dr. J. Verhoef dank ik voor zijn belangstelling voor dit onderzoek en de geboden hulp bij het uitvoeren van fagocytose experimenten.

Dr. 0.M. Neijssel. Dense, het voorliggend proefschrift is een voorbeeld van een goede interuniversitaire samenwerking. Niet alleen onze geregelde discussies, doch ook de vele, vaak telefonische, adviezen hebben steeds een stimulerende invloed gehad. Jouw optimisme en kritische aanpak hebben geleid tot het verkregen resultaat. Ook wil ik je bedanken voor de enorme steun bij het corrigeren van de vele manuscripten.

Dr. J.T.M. Wouters. Jan, jouw kennis op het gebied van celwanden en competitie experimenten in continue cultuur waren van onschatbare waarde voor dit onderzoek. Ik hoop dat je jouw aandeel herkent in dit proefschrift.

Drs. W.J. van Leeuwen ben ik zeer dankbaar voor het karakteriseren van de vele $S$. aureus stammen en de isolatie van diverse plasmiden.

Miriam Kamps ben ik zeer dankbaar voor de uitvoering van de vele experimenten en het tekenen van de figuren. 
Ik besef dat mijn, soms chaotische, manier van werken je dikwijls tot wanhoop heeft gebracht. Zonder je kritische en nauwgezette werkwijze zou dit onderzoek niet mogelijk zijn geweest.

Puck Muller dank ik voor het oplossen van vele stolperikelen en het standaardiseren van humaan PPSB.

Hans Hendrix dank ik voor zijn hulp bij de zuivering van stafylocoagulase.

Fia Claus dank ik voor de enthousiaste wijze waarop zij met veel geduld mijn hiërogliefen steeds weer in voortreffelijk type-werk heeft weten om te zetten.

Jacques Beckers, Michel Beesmans en Gerry Tilly worden bedankt voor de sterilisatie van de kweekapparatuur en de 4182 liter kweekmedium.

De medewerkers van de Algemene Instrumentele Dienst dank ik voor het modificeren van de kweekapparatuur.

Tenslotte gaat mijn waardering uit naar alle collega's van het Biomedisch Centrum, omdat zij altijd bereid waren medewerking in welke vorm dan ook te verlenen. 


\section{ABBREVIATIONS}

BHI Brain Heart Infusion

BSA Bovine serum albumin

D Dilution rate

DNA Deoxyribonucleic acid

DOC Dissolved oxygen concentration

EDTA Ethylene diaminetetraacetic acid

EMS Ethyl methanesulphonate

$K_{s} \quad$ Growth-limiting substrate concentration giving half-maximal growth rate

$\mathrm{LD}_{50}$ Medium dose that kills 50\% of the animals

$\mu$ Specific growth rate

NB Nutrient broth

PBS Phosphate buffered saline

PPSB Prothrombin, proconvertin, Stuart-Prower factor, antihaemophilic factor $B$

$\mathrm{Q}_{2} \quad \mu 1$ oxygen consumed per $\mathrm{mg}$ dry wt organisms and per hour

$\mathrm{qO}_{2} \quad \mu m o l$ oxygen consumed per mg dry wt organisms and per hour

RNA Ribonucleic acid

SC Staphylocoagulase

TEP Total extracellular protein

Tris Tris (hydroxymethyl) aminomethane 


\section{INTRODUCTION}

Staphylococcus aureus is a remarkably versatile species, which has been very successful in establishing itself as a commensal in various niches on the human and animal body (55).

Staphylococcal carriage is present in $20-40 \%$ of the general human population whereas hospital personnel and patients often have higher carrier rates, up to $90 \%$ ( 31 , $35,83)$. In the latter groups, these staphylococci are often resistant to one or more antibiotics in use. S. aureus is located primarily in the anterior nares and to a lesser extent on the perineum. In 70-90\% of the population $S$. aureus can be isolated transiently from at least one site (generally the skin) (26, 84). Although in the large majority of cases this carriage state is one of peaceful commensalism ( 83$)$, it is clear that carriers of staphylococci are at greater risk of acquiring infective lesions (19), since there is no evidence that the carriage of staphylococci in the nose or on the skin leads to immunity to staphylococcal infections (23). Besides patients with staphylococcal lesions, asymptomatic carriers are potential sources of hospitalacquired S. aureus infections. Generally, there is a steady increase in the acquisition of staphylococci, the longer a patient stays in hospital.

Many reports agree that $S$. aureus is not usually dispersed by droplet transmission but rather is disseminated by transfer of the organisms from the nose or perineum to the skin, clothing and bedding of the carrier. From these areas there is a potential of $S$. aureus being spread, particularly by hand contact to other persons of inanimate sources (58). Furthermore the development of nasal carriage seems to correlate better with the epidemic virulence of a staphylococcal strain than with air contamination. In general, disinfection of the skin reduces cross-infections more effectively than nasal disinfection (66). Cross-infection from one human to another is extremely common; it is sometimes airborne but in the majority of cases the result of direct or indirect contact. The ubiquity of staphylococcil in the population is such that elimination of the human reser- 
voir would appear virtually impossible.

Although in the general population serious infections due to 5 . aureus are relatively rare, they continue to be a major source of morbidity and mortality in a hospital-based practice. S. aureus can interfere with surgical wound healing, cause septicemia and endocarditis, colonize burns and is often the cause of osteomyelitis and furuncolosis, especially in the immune-compromised host. In the last two decades the number of these susceptible patients has increased considerably $(9,57)$.

Intact skin and slime layers are generally thought to be the primary defence against soft tissue infections by 5. aureus (which are the most in common) (26), although in humans it has been surprisingly difficult, even after breaking the skin, to produce experimental infections $(16,51,67)$.

Once the outer barriers have been breached, phagocytosis and intracellular killing of the staphylococcus by leucocytes represent the major line of defence of the host against infection. These two processes require complex interactions between bacterial cell surfaces and soluble factors in serum (opsonins) on the one hand and phagocytic cells on the other (78). Recurrent or severe infections may result from a defective host response in any step of these complex interactions $(57,62,79)$.

The virulence of $S$. aureus is based on cell-surface components such as peptidoglycan, protein $A$, teichoic acid, capsular material $(24,60,80)$ and a large number of extracellular proteins, which are believed to have biologic effects on the intended host $(1,64,86)$. Because of a high correlation between the virulence factors of $S$. aureus and the observed pathogenicity in man, many attempts have been made to relate staphylococcal virulence to these factors. Few of these factors have been demonstrated as a pathogenic link between the staphylococcus and staphylococcal disease $(1,57)$. With respect to the exoproteins, staphylocoagulase has been found to accompany pathogenicity most consistently, although virulent staphylocoagulase-negative as well as avirulent staphylocoagulase-positive strains have been reported $(1,4,23,26)$.

In addition, the ability to produce staphylocoagulase is by definition one of the main criteria used to distinguish S. aureus from other staphylococci (5). Although staphylocoagulase-negative staphylococci were generally considered as non-pathogenic commensal bacteria of the human skin, there is an increasing awareness during the last ten years that these organisms can cause a variety 
of infections including bacteremia, endocarditis, infections associated with foreign bodies such as ventriculo-atrial shunts and cardiac valve protheses, and especially infections of the urinary tract (59).

This chapter will review the mode of action of staphylocoagulase and its role in the pathogenesis of S. aureus. The objectives of the thesis are further delineated in the last section of this chapter.

\section{I PURIFICATION AND MODE OF ACTION OF STAPHYLOAGULASE}

In 1903 Loeb (49) demonstrated the specific action of 5 . aureus in clotting goose plasma in vitro and he proposed a correlation between the clotting ability of staphylococci and pathogenicity. These findings were confirmed by Munch (56). Later investigations of Gratia (32) revealed that the coagulation was due to a protein excreted by the organism. This protein was called staphylocoagulase.

Studies of Smith and Hale (68) provided evidence that besides fibrinogen, a second plasma factor was required for the action of staphylocoagulase. This substance, first called activator by Smith and Hale, was labeled Coagulase Reacting Factor (CRF) by Tager (73).

It was proposed that CRF was identical to prothrombin and that a complex between staphylocoagulase and prothrombin was formed. Subsequently, this complex would be able by virtue of thrombin-like activity to convert fibrinogen into fibrin, the actual coagulation reaction (74). Neither the coagulation nor the esterase activity of this complex is inhibited by heparin, hirudin or antithrombin III which are potent inhibitors of thrombin activity (70).

Since 1948 a large number of reports have been published dealing with the purification of staphylocoagulase, but with almost all of these preparations none were of sufficient homogeneity to assess the mode of action of staphylocoagulase.

Duthie (18) showed that 5 . aureus produced two forms of staphylocoagulase: a free staphylocoagulase which was secreted into the cultivation medium and a boundcoagulase. However, the latter differs completely from free staphylocoagulase with respect to mode of action and antigenicity and was therefore called clumping factor $(18,74)$.

With a highly purified preparation of staphyloco- 
agulase Hemker and co-workers $(7,36)$ characterized this protein and resolved its mode of action. Staphylocoagulase, produced by 5 . aureus strain 104 is a single chain protein with a molecular weight of 61000 , aspartic acid as the $N$-terminal amino acid and an isoelectric point of 4.53. The protein does not contain (phospho)lipid or carbohydrate residues.

The activation of human prothrombin by staphylocoagulase occurs stoichiometrically, one molecule of staphylocoagulase forming a complex with one of prothrombin without splitting of peptide bonds. This complex i.e. staphylothrombin has antigenic determinants in common wit prothrombin and staphylocoagulase but not with thrombin. Moreover, the amino acid composition of staphylothrombin equals the sum of the amino acid compositions of staphylocoagulase and prothrombin. Therefore, the thrombin-like activity of this complex is probably not due to proteolytic breakdown of prothrombin to thrombin but to a change of the tertiary structure of prothrombin that unmasks a thrombin-like active centre. The coagulation reaction brought about by staphylocoagulase is independent of $\mathrm{Ca}^{2+}$ ions, phospholipids and other blood clotting factors whereas staphylocoagulase by itself does not possess proteolytic or esterase activity.

Similar results were obtained by $Z a j$ del et al. who have used a staphylocoagulase preparation produced by a bovine strain of 5 . aureus. The changes brought about by thrombin and staphylothrombin in the substrate fibrinogen are identical as indicated by the change in nitrogen percentage, structure of the individual fibrinogen peptides and the endgroups of the fibrin monomers (87).

Recently Lindhout et al. (47) demonstrated with purified staphylocoagulase, prepared by a bovine prothrombin-sepharose chromatography column, that staphylocoagulase and prothrombin form a firm, equimolar complex, i.e. staphylothrombin with a dissociation constant less than $10^{-11} \quad M$. Furthermore, they confirmed the observation of Hemker et al. (36) that proteolysis cannot account for the generation of thrombin-like activity. The thrombin-like activity can be generated as a result of the interactions between staphylocoagulase and human prethrombin 1, human prethrombin 2 or bovine prethrombin 2. Interaction between staphylacoagulase and thrombin give a complex in which the thrombin activity cannot be inhibited by antithrombin III and hirudin. Finally, staphylothrombin does not possess activity 
towards factor $V$, factor VIII and platelets. Kawabata et al. (43) also demonstrated that staphylocoagulase binds in the prethrombin-2 region of prothrombin.

During administration of vitamin $K$ antagonists, vitamin $K$-dependent coagulation factors enter the plasma in an abnormal form as the so-called "proteins induced by vitamin $K$ absence" (PIVKA's) (37). It has been postulated that the discrepancy between the assays for CRF and prothrombin during anticoagulant treatment is due to the fact that although PIVKA-II has no activity in the normal tests for prothrombin, it does have a CRF activity (39). Bas et al. (8) demonstrated that staphylocoagulase not only reacts with normal prothrombin but also with the precursor of prothrombin, PIVKA-II. Therefore, staphylocoagulase finds a new application in the determination of PIVKA-II during anticoagulant therapy.

Intravenous application of staphylocoagulase in a sub-lethal dose in rabbits results, after three hours, in a decrease of the fibrinogen level to about $55 \%$ of the initial value; the levels of factor $V$ and factor VIII are not affected by staphylocoagulase. After 16 hours, the level of fibrinogen rises by about 200\% whereas the levels of the factors $V$ and VIII were increased by $40 \%$ (87). A lethal dose of staphylocoagulase results in a rapid defibrination and the death of the rabbit in 10-20 min after the intravenous injection, due to fibrin deposits in kidney capillaries, adrenals, liver and small and large lung vessels $(69,71,87)$.

Using literature data, Elek (26) presented conclusive evidence that staphylocoagulase is antigenic and that antibodies to the antigen can be raised in vivo. At least four antigenically distinct staphylocoagulases have been demonstrated $(17,63)$. A close relationship between the bacteriophage group of staphylococcal strains and the antigenic specificity of the staphylocoagulase produced by the corresponding strains was observed by Barber and Wildy (6). In addition, staphylococci of phage type 3A (group II) and $42 \mathrm{E}$ (group III) produce staphylocoagulases which are antigenically distinct from those produced by other strains of group II and III, respectively.

The observations of Barby and Wildy were confirmed by Blobel and Berman (10), but the differences in the antigenicity of the staphylocoagulases did not appear to be sufficiently distinct to justify a classification of staphylococci for epidemiologic investigation.

Nevertheless, Zen-Yoji et al. (88) reported that staphylocoagulase existed in seven antigenically dis- 
tinct different types and that staphylocoagulase-positive staphylococci could be classified by staphylocoagulase typing (89). Recently, Ushioda and co-workers (76) were able to classify almost all staphylocoagulasepositive staphylococci into eight types by staphylocoagulase typing. Following this method, Dekio and Onimura (15) indicated that relationships were obviously present between the various dermatoses and the staphylocoagulase types of the 5 . aureus strains isolated from their lesions.

Up to this point, all evidence indicated that a single $S$. aureus strain produces a single antigenic type of staphylocoagulase. However, Henderson and Brodie (38) found that a given strain could produce either a single staphylocoagulase or as many as four antigenically distinct types, suggesting heterogeneity or multiple molecular forms of the protein. Miale et al. (54) demonstrated even five so-called staphylococcal isocoagulases. However, when staphylocoagulase was purified more extensively, this number had decreased considerably.

Generally, staphylocoagulase reacts not only with plasma of the animal or human species from which the corresponding 5 . aureus strain is isolated, but also with plasma of other species. Although this phenomenon has been reported repeatedly in the literature, no explanation was given $(33,48,85)$. With the present knowledge of the mode of action of staphylocoagulase, it is very likely that every staphylocoagulase has a certain specificity towards prothrombin of various species.

\subsection{ROLE OF STAPHYLOCOAGULASE IN THE PATHOGENESIS OF S. ALIREUS}

In 1945, Hale and Smith (34) suggested that the production of staphylocoagulase protected 5 . aureus from phagocytosis. Staphylocoagulase-positive staphylococci were poorly phagocytized when suspended in citrated blood, which contains fibrinogen, whereas rapid phagocytosis occurred in defibrinated blood. On the other hand staphylocoagulase-negative staphylococci were phagocytized with equal avidity by polymorphonuclear leucocytes, irrespective of whether they were suspended in citrated or defibrinated blood. Furthermore, it was demonstrated in stained films, that the plasma-treated staphylocoagulase-positive staphylococci were surrounded by a fibrin deposit. Therefore, it was concluded that staphylocoagulase forms a barrier of fibrin around the bacteria which protects them from phagocytosis. 
Cawdery et al. (13) disputed the results of Smith and Hale. They showed that the process of defibrination resulted in a significant loss of leucocytes from the blood and that therefore the number of staphylococci phagocytized was greater in defibrinated than in citrated blood. When the number of leucocytes was adjusted so that the counts in the defibrinated and citrated blood were equal, no difference was found in the numbers of staphylocoagulase-positive and staphylocoagulase-negative staphylococci phagocytized. Although several authors reported that sera of patients, suffering from chronic staphylococcal infections, contain high titres of antibodies to staphylocoagulase, protection experiments by immunization with staphylocoagulase against an experimental staphylococcal infection give non-consistent results $(21,23)$.

Melly et al. (53) observed that staphylocoagulasepositive staphylococci survived in small numbers within the cytoplasm of human granulocytes for prolonged periods of time whereas staphylocoagulase-negative staphylococci appeared to be destroyed rapidly.

When staphylocoagulase-negative strains of 5 . aureus were suspended in solutions of partially purified staphylocoagulase and injected intracerebrally into mice, a significant mortality resulted; organisms or staphylocoagulase alone injected at the same dose level were shown to be innocuous (25). However, studies of Kapral and co-workers $(41,42,46)$ and of Van der Vijver et al. (77) with staphylocoagulase-negative mutants revealed no difference in virulence between the wild type and the mutant strains.

Another role of staphylocoagulase as a virulence factor of $\mathrm{S}$. aureus was proposed by Bullen et al. (12). Many staphylocoagulase-positive strains of $\underline{5}$. aureus grow readily in serum while staphylocoagulase-negative strains grow much more slowly if at all. The addition of purified staphylocoagulase to serum abolished the inhibitory effect (22). Schadé (65) demonstrated that the growth rate of $\mathrm{S}$. aureus in human serum was directly correlated with the percentage of iron-saturation of transferrin and that 5 . epidermidis did not grow in normal serum unless transferrin was saturated with iron. From these observations, Bullen et al. concluded that staphylocoagulase might possibly be involved in making iron available from transferrin to the bacterial cells.

This idea was supported by experiments of Marcelis et al. (50) in which it was shown that the growth of 5. epidermidis could be inhibited completely by the 
addition of transferrin whereas the growth of $S$. aureus was not affected. However, it cannot be concluded that the observed phenomena were due exclusively to staphylocoagulase since both 5 . aureus and $\underline{5}$. epidermidis produce iron-chelating substances (50).

Apart from a possible role of staphylocoagulase in the release of iron from transferrin, it has to be stressed that the availability of iron for micro-organisms during the infection process is of great importance. A large number of publications have revealed the vigorous competition for growth-essential iron between micro-organisms and their hosts. The latter possess an array of mechanisms to withhold iron; the ability of micro-organisms to overcome these mechanisms is an important component of virulence $(29,82)$.

From these studies it can be concluded that the mechanism by which staphylocoagulase may increase the persistence of 5 . aureus during the infection process is by no means understood and that a correlation between the ability to produce staphylocoagulase and the virulence of $\mathrm{S}$. aureus has not been established. Therefore it is now assumed that in general the virulence of a 5. aureus strain is determined by a combination of factors.

\subsection{INTRODUCTION TO THE THESIS}

5. aureus is an extremely adaptale micro-organism capable of rapidly changing its genotypic and phenotypic characteristics (55). The development of staphylococcal resistance to many antimicrobial agents which has led to a world-wide increase of multiresistant hospital strains during the period 1940-1960 is an example of this adaptability $(45,61)$.

Not only the composition of the cell-wall but also the amount and variety of the extracellular proteins are strongly dependent upon growth conditions $(3,4,11$, 30). Therefore by changing its antigenic structure and opsonic requirements, $\underline{5}$. aureus can present a different "face" to the host, leading to a less efficient phagocytosis and subsequently to a delayed healing process (24). Thus, the virulence of 5 . aureus may vary according to the environment in which the staphylococci grow $(2,29,40)$. Consequently, the initial stage and the course of the staphylococcal infections will be greatly influenced by environnental conditions. This is illustrated by two examples: staphylococci in vivo are more resistant to intracellular killing by polymorphonuclear 
leucocytes than organisms grown in vitro (2); S. aureus strains which failed to produce a-haemolysin and leucocidin in vitro, produced high amounts of these enzymes in vivo (28). However, few data are available about the environmental conditions under which 5 . aureus grows in vivo.

Gladstone and Glenncross (28) showed that the growth rate of $S$. aureus in vivo had decreased considerably compared to that in vitro. Moreover, they pointed out that 5 . aureus grew under axygen-limited growth conditions in their experiments.

From recent studies, it can be calculated that, in vivo, S. aureus multiplies with growth rates in the range of $0.12-0.35 h^{-1}$ (generation times of 2-6 hours) (14, 44, $81)$. Thus, it is likely that, in vivo, 5 . aureus will be growing at submaximal rates, presumably as a consequence of substrate-limited growth conditions.

Since staphylocoagulase production is still considered to accompany pathogenicity of $S$. aureus most consistently, the production of this exoprotein under these growth conditions was chosen for further study. The following aspects of staphylocoagulase production by S. aureus were investigated in this thesis:

1. Studies in batch cultures revealed that the production by $\mathrm{S}$. aureus is dependent on strain type, composition of the cultivation medium, temperature, inoculum size, growth phase, $\mathrm{pH}$ and aeration efficiency $(20,27,52,72,75)$. Therefore a new investigation was undertaken to assess the effects of medium composition and environmental factors on the formation of staphylocoagulase by $\mathrm{S}$. aureus strain 104 when grown in batch cultures. This strain was chosen because high yields of staphylocoagulase had been obtained with it previously (Chapter 2).

2. Since, in contrast to a batch culture, the chemostat provides a defined and reproducible environment in which micro-organisms can grow under steady-state conditions at submaximal rates, continuous cultures with strain 104 and with two bovine strains of 5 . aureus were set up and the effect of various environmental parameters on their production of staphylocoagulase was studied (Chapter 3 ).

3. In order to elucidate the possible mechanisms involved in the secretion of staphylocoagulase, the influence of cerulenin, quinacrine and protein synthesis inhibitors on the production of staphylocoagulase in magnesium- and oxygen-limited chemostat cultures of $\mathrm{S}$. aureus 104 was investigated (Chapter 4). 
4. During prolonged growth of 5 . aureus strain 104 and strain NCTC 8178 in continuous culture, staphylocoagulase-negative mutants accumulated in the chemostat. The characteristics of these mutant strains and their competitive ability with respect to their parent strains in chemostat cultures under different growth conditions were established.

Furthermore these staphylocoagulase-negative strains were used to elucidate the regulation of the synthesis of staphylocoagulase and of exoproteins in general.

5. Since the ability to produce staphylocoagulase is a generally accepted criterion for the identification of $\mathrm{S}$. aureus, the availability of a reliable assay method of staphylocoagulase is indispensable. Therefore, a rapid and direct assay of staphylocoagulase for the routine identification of $S$. aureus using the chromogenic substrate Chromozym $\overline{\mathrm{TH}}$ was developed (Chapter 6). 


\section{REFERENCES}

1. Abramson, C. 1972. Staphylococcal enzymes. p. 187-248. In J.0. Cohen, (ed.), The Staphylococci. Wiley-Interscience, New York.

2. Adlam, C., Pearce, J.H., and Smith, H. 1970. Virulence mechanisms of staphylococci grown in vivo and in vitro. J. Med. Microbiol. 3: 114-156.

3. Archibald, A.R. 1972. The chemistry of staphylococcal cell walls. p. 75-100. In J.0. Cohen, (ed.), The staphylococci. Wiley-Interscience, New York.

4. Arvidson, 5., Björklind, A., Erikson, R., and Holme, T. 1976. Enzymes from Staphylococcus aureus. p. 238250. In A.C.R. Dean, D.C. Ellwood, C.G.T. Evans, and J. Melling, (eds.), Continuous culture: applications and new fields. Vol. 6. Ellis Horwood, Chichester.

5. Baird-Parker, A.C., Hill, L.R., Kloos, W.C., Koccur, M., Deding, P., and Schleifer, K.K. 1976. Appendix 1. Identification of staphylococci. Subcommittee on the taxonomy of staphylococci and micrococci. Int. J. Syst. Bacteriol. 26: 333-334.

6. Barby, M., and Wildy, P. 1958. A study of the antigenic specificity of staphylococcal coagulase in relation to bacteriophage group. J. Gen. Microbiol. 18: $92-106$.

7. Bas, B.M., Muller, A.D., and Hemker, H.C. 1974. Purification and properties of staphylocoagulase. Biochim. Biophys. Acta 379: 164-171.

8. Bas, B.M., Muller, A.D., and Van der Voort-Beelen, J.M. 1975. The relation between staphylocoagulase reacting factor and proteins induced by vitamin $K$ antagonists. J. Mol. Med. 1: 65-72.

9. Benenson, A.5. 1975. Control of communicable diseases in man, p. 298. The American Public Health Association, Washington.

10. Blobel, H., and Berman, D.T. 1960. Serologic studies of purified staphylocoagulase with special reference to fluorescence microscopy. J. Immunol. 85: 244-249.

11. Bull, A.T. 1972. Envirommental factors influencing the synthesis and excretion of exocellular macromolecules. J. Appl. Chem. Biotechnol. 22: 261-292.

12. Bullen, J.J., Rogers, H.J., and Griffiths. 1974. Bacteiral iron metabolism in infection and immunity. p. 518-551. In J.B. Neilands, (ed.), Microbial iron metabolism; a comprehensive treatise. Academic Press, New York. 
13. Cawdery, M., Forster, W.D., Hawgood, B.C., and Taylor, C. 1969. The role of coagulase in the defence of Staphylococcus aureus against phagocytosis. Br. J. Exp. Pathol. 50: 408-412.

14. Day, S.E.J., Vasli, K.K., Russell, R.J., and Arbuthnott, J.P. 1980. A simple method for the study in vivo of bacterial growth and accompanying host response. J. Infect. 2: 39-51.

15. Dekio, 5., and Onimura, K. 1981. Coagulase types of coagulase-positive staphylococci from bacterial skin infections. J. Dermatol. 8: 223-228.

16. Duncan, W.C., McBride, M.E., and Knox, J.M. 1970. Experimental production of infections in human. J. Invest. Dermatol. 54: 319-323.

17. Duthie, E.S. 1952. Variation in antigenic composition of staphylococcal coagulase. J. Gen. Microbiol. 7: $320-326$.

18. Duthie, E.S. 1954. Evidence for two forms of staphylococcal coagulase. J. Gen. Microbiol. 10: 427-436.

19. Duthie, S.R., Agarwal, D.S., and Gulati, S.M. 1976. Carriage of Staphylococcus and its importance in infection of the hospitalised and non-hospitalised patients. Indian J. Pathol. Microbiol. 19: 97-108.

20. Duthie, E.5., and Haughton, G. 1958. Purification of free staphylococcal coagulase. J. Gen. Microbiol. 70: 125-134.

21. Duthie, E.S., and Lorenz, L.L. 1952. Staphylococcal coagulase: mode of action and antigenicity. J. Gen. Microbial. 6: 95-107.

22. Ekstedt, R.D. 1956. Further studies on the antibacterial activity of human serum on Micrococcus pyogenes and its inhibition by coagulase. J. Bacteriol. 72: 157-161.

23. Ekstedt, R.D. 1972. Immunity to the staphylococci. p. 385-418. In J.0. Cohen, (ed.), The staphylococci. Wiley-Interscience, New York.

24. Ekstedt, R.D. 1974. Immune response to surface antigens of Staphylococcus aureus and their role in resistance to staphylococcal disease. Ann. N.Y. Acad. Sci. 236: 203-220.

25. Ekstedt, R.D., and Yotis, W.W. 1960. Studies on staphylococci. II. Effect of coagulase on the virulence of coagulase-negative strains. J. Bacteriol. 80: 496-500.

26. Elek, S.D. 1959. Staphylococcus pyogenes and its relation to disease. Livingston, Ltd., Edinburgh. 
27. Fahlberg, W.J., and Marston, J. 1960. Coagulase production by Staphylococcus aureus. I. Factors influencing coagulase production. J. Infect. Dis. 106: 111115 .

28. Gladstone, G.P., and Glenncross, E.J.G. 1960. Growth and toxin production of staphylococci in cellophane sacs in vivo. Br. J. Exp. Pathol. 41: 313-330.

29. Gladstone, G.P., Walton, E., and Kay, K. 1974. The effect of cultural conditions on the susceptibility of staphylococci to killing by cationic proteins from rabbit polymorphonuclear leukocytes. Br. J. Exp. Pathol. 55: 427-435.

30. Glenn, A.R. 1976. Production of extracellular proteins by bacteria. Ann. Rev. Microbiol. 30: 41-62.

31. Godfrey, M.E., and Smith, I.M. 1958. Hosptial hazards of staphylococcal sepsis. J. Amer. Med. Ass. 166: 1197-1199.

32. Gratia, A. 1919. De la coagulation du plasma oxalaté par le staphylocoque. Compt. Rend. Soc. Biol. (Paris) 82: 1393-1394.

33. Hájek, V., and Marsálek, E. 1971. The differentiation of pathogenic staphylococci and a suggestion for their taxonomic classification. Zbl. Bakt. Hyg., I. Abt. Drig. A. 217: 176-182.

34. Hale, J.H., and Smith, W. 1945. The influence of coagulase on the phagocytosis of staphylococci. Br. J. Exp. Pathol. 26: 209-216.

35. Hare, R., and Ridley, M. 1958. Further studies on the transmission of Staphylococcus aureus. Br. Med. J. 1: 69-73.

36. Hemker, H.C., Bas, B.M., and Muller, A.D. 1975. Activation of a pro-enzyme by a stoichiometric reaction with another protein. The reaction between prothrombin and staphylocoagulase. Biochim. Biophys. Acta 379: 180-188.

37. Hemker, H.C., Veltkamp, J.J., Henson, A., and Loeliger, E.A. 1963. Nature of prothrombin synthesis: preprothrombinaemia in vitamin $K$ deficiency. Nature (London) 200: 589-590.

38. Henderson, A., and Brodie, J. 1963. Investigations on staphylococcal coagulase. Br. J. Exp. Pathol. 44: 524528. 
39. Josso, F., Lavergne, J.M., Gouault, M., Prou-Wartelle, D., and Soulier, J.P. 1968. Différents état moléculaires du facteur II (prothrombine). Leur étude à I'aide de la staphylocoagulase et d'anticorps antifacteur II. I. Le facteur II chez les sujets traités par les antagonistes de la vitamine K. Thromb. Diath. Haemorrh. 20: 88-98.

40. Kapral, F.A. 1974. Staphylococcus aureus: Some thostparasite interactions. Ann. N.Y. Acad. Sci. 236: 267276.

41. Kapral, F.A., and Li, I.W. 1960. Virulence and coagulases of Staphylococcus aureus. Proc. Soc. Exp. Biol. Med. 104: 151-153.

42. Karas, E.M., and Kapral, E.A. 1962. Virulence and coagulases of Staphylococcus aureus. III. Survival of certain coagulase-negative mutants in the organs of intravenously infected mice. J. Infect. Dis. 111: 209214.

43. Kawabata, 5., Morita, T., Igarashi, H., and Iwanaga, 5. 1981. Enzymatic properties of staphylocoagulase human prothromin complex (Staphylothrombin). Thrombos. Haemostas is $46: 47$.

44. Kinsman, 0.S., and Arbuthnott, J.P. 1980. Experimental staphylococcal infection in newborn mice: inhibition of weight gain as an index of virulence. J. Med. Microbiol. 13: 281-290.

45. Lacey, R.W., and Richmond, R.H. 1974. The genetic basis of antibiotic resistance in S. aureus: the importance of gene transfer in the evolution of this organism in the hospital environment. Ann. N.Y. Acad. Sci. 236: 395-412.

46. Li, I.W., and Kapral, F.A. 1962. Virulence and coagulases of Staphylococcus aureus. II. Survival of certain coagulase-negative mutants in the organs of intravenously infected rabbits. J. Infect. Dis. 111: 204-208.

47. Lindhout, M., Hendrix, H., and Henker, H. 1981. Complex formation between prothrombin and staphylocoagulase. Thrombos. Haemostasis 46: 121 .

48. Live, I. 1972. Staphylococci in animals: Differentiation and relationship to human staphylococcosis. p. 443-456. In J.0. Cohen, (ed.), The staphylococci. Wiley-Interscience, New York.

49. Loeb, L. 1903. The influence of certain bacteria on the coagulation of the blood. J. Med. Res. 10: 407419. 
50. Marcelis, J.H., Den Daas-Slagt, H.J., and HoogkampKorstanje, J.A.A. 1978. Iron requirement and chelator production of staphylococci, Streptococcus faecalis and enterobacteriaceae. Antonie van Leeuwenhoek 44: 257-267.

51. Marples, R.R., and Kligman, A.M. 1976. Experimental staphylococcal infections of the skin in man. p. 755760. In J. Jeljaszewicz, (ed.), Staphylococci and staphylococcal disease. Gustav Fischer Verlag, Stuttgart.

52. Marston, J., and Fahlberg, J. 1960. Coagulase production by Staphylococcus aureus. II. Growth and coagulase production in complex and chemically defined mediums. J. Infect. Dis. 106: 111-122.

53. Melly, M.A., Thomison, J.B., and Rogers, D.E. 1960. Fate of staphylococci within human leucocytes. J. Exp. Med. 112: 1121-1130.

54. Miale, J.B., Winningham, A.R., and Kent, J.W. 1963. Staphylococcal isocoagulases. Nature (London) 1973: 392.

55. Mudd, S. 1970. A successful parasite: Parasite host interactions in infection by Staphylococcus aureus. $p$. 197-227. In S. Mudd, (ed.), Infections agents and host reactions. W.B. Saunders Co., Philadelphia.

56. Munch, H. 1908. Ueber eine Vorstufe des Fibrinferments in Kulturen von Staphylococcus aureus. Biochem. Z. 14: 143-155.

57. Musher, D.M., and Dlbricht-McKenzie, 5. 1977. Infections due to staphylococcus aureus. Medicine 56: 383409.

58. Nahmias, A.J., and Shulman, J.A. 1972. Epidemiologic aspects and control methods. p. 483-502. In J.0. Cohen, (ed.), The staphylococci. Wiley-Interscience, New York.

59. Namavar, F., De Graaff, J., and MacLaren, D.M. 1978. Taxonomy of coagulase-negative staphylococci: a comparison of two widely used classification scheme. Antonie van Leeuwenhoek 44: 425-434.

60. Peterson, P.K., Wilkinson, B.J., Kim, Y., Schmeling, D., and Quie, P.G. 1978. Influence of encapsulation on staphylococcal opsonization and phagocytosis by human polymorphonuclear leukocytes. Infect. Immun. 19: 943949.

61. Plorde, J.J., and Sherris, J.C. 1974. Staphylococcal resistance to antibiotics: origin, measurement and epidemiology. Ann. N.Y. Acad. Sci. 236: 413-434. 
62. Quie, P.G., Hill, H.R., and Davis, A.T. 1974. Defective phagocytosis of staphylococci. Ann. N.Y. Acad. Sci. 236: 233-243.

63. Rammelkamp, C.H., Hezebicks, M.M., and Dingle, J.H. 1950. Specific coagulases of Staphylococcus aureus. J. Exp. Med. 91: 295-307.

64. Rogolsky, M. 1979. Nonenteric toxins of Staphylococcus aureus. Microbiol. Rev. 43: 320-360.

65. Schade, A.L. 1963. Significance of serum iron for the growth, biological characteristics, and metabolism of Staphylococcus aureus. Biochem. Z. 338: 140-148.

66. Selwyn, 5. 1965. The mechanism and prevention of cross infection in dermatological wounds. J. Hyg. 63: 59-71.

67. Singh, G., Marples, R.R., and Kligman, A.M. 1971. Experimental Staphylococcus aureus infections in humans. J. Invest. Dermatol. 57: 149-158.

68. Smith, W., and Hale, J.H. 1944. The nature and mode of action of staphylococcus coagulase. Br. J. Exp. Pathol. 25: 101-110.

69. Smith, D.D., and Johnstone, J.M. 1958. Staphylocoagulase activity in vitro. Br. J. Exp. Pathol. 39: 165170.

70. Soulier, J.P., and Prou-Wartelle, 0. 1967. Study of thrombin coagulase. Thrombos. Diathes. Haemorrh. 23: 37-49.

71. Soulier, J.P., and Prou-Wartelle, 0. 1967. Effects de l'injections de staphylocoagulase chez de lapin. Essai de prevention du syndrome de defibrination. Nouv. Rev. Franc. Hématol. 7: 779-800.

72. Stutzenberger, F.J., and San Clemente, C.L. 1968. Production and purification of staphylococci coagulase in a semi-defined medium. Amer. J. Vet. Res. 29: 11091116.

73. Tager, M. 1948. Concentration, partial purification properties, and nature of staphylocoagulase. Yale J. Biol. Med. 20: 488-500.

74. Tager, M., and Drummond, M.C. 1965. Staphylocoagulase. Ann. N.Y. Acad. Sci. 128: 92-111.

75. Tirunarayanan, M.0. 1966. Investigations on the enzymes and toxins of staphylococci. Stimulation of coagulase biosynthesis by glucose and bicarbonate. Acta Pathol. Microbiol. Scand. 68: 273-380.

76. Ushioda, H., Terayama, T., Shingaki, M., Sakai, S., and Zen-Yoji, H. 1976. Identification of a new antigenic type of staphylococcal coagulase, coagulase type VIII. Ann. Res. Tokyo Metr. Res. Lab. P.H. 27: 1-4. 
77. Van der Vijver, J.C.M., Van Es-Boon, M.M., and Michel, M.F. 1975. A study of virulence factors with induced mutants of Staphylococcus aureus. J. Med. Microbiol. 8: $279-287$.

78. Verbrugh, H.A. 1979. The phagocytic response in host resistance against staphylococcal infections. Ph.D. Thesis, State University Utrecht.

79. Verbrugh, H.A., Van Dijk, W.C., Hendrickx, Y.F.M., Van der Stadt, D., Stoop, J.W., Peterson, P.K., and Verhoef, J. 1980. Phagocytic and chemotactic function of polymorphonuclear and mononuclear leucocytes in patients with recurrent staphylococcal infection. Scand. J. Infect. Dis. 12: 111-116.

80. Verbrugh, H.A., Van Dijk, W.C., Peters, R., Van der Tol, M.E., and Verhoef, J. 1979. The role of Staphylococcus aureus cell-wall peptidoglycan, teichoic acid and protein $A$ in the process of complement activation and opsonization. Immunol. 37: 615-621.

81. Watson, D.L., and Prideaux, J.-A. 1979. Comparisons of Staphylococcus aureus grown in vitro and in vivo. Microbiol. Immunol. 23: 543-547.

82. Weinberg, E.D. 1978. Iron and Infection. Microbiol. Rev. 42: 45-66.

83. Williams, R.E.0. 1963. Healthy carriage of Staphylococcus aureus, its prevalence and importance. Bacteriol. Rev. 27: 56-71.

84. Williams, R.E.O. 1965. Pathogenic bacteria on the skin. p. 49-65. In H.I. Maibach, and G. Hildick-Smith, (eds.), Skin bacteria and their role in infection. McGraw-Hill Book Co., New York.

85. Wilson, G.S., and Miles, A., 1975. Topley and Wilson's principles of bacteriology, virology and immunity. p. 782. Edward Arnold, London.

86. Wiseman, G.M. 1975. The hemolysins of Staphylococcus aureus. Bacteriol. Rev. 39: 317-344.

87. Zajdel, M., Wegrzynowicz, Z., Sawecka, J., Jeljaszewicz, J., and Pulverer, G. 1976. Mechanisms of action of staphylocoagulase. p. 549-575. In J. Jeljaszewicz, (ed.), Staphylococci and staphylococcal diseases. Gustav Fischer Verlag, Stuttgart.

88. Zen-Yoji, H., Terayama, T., Benoki, M., and Kuwahara, 5. 1961. Studies on staphylococcal coagulase. I. Antigenic difference of coagulase and distribution of the anti-coagulase in human sera. Jap. J. Microbiol. 5: 237-247. 
89. Zen-Yoji, H., Terayama, T., Benoki, M., and Kuwahara, S. 1961. Studies on staphylococcal coagulase. II. Coagulase typing of staphylococci ad its relation to phage typing. Jap. J. Microbiol. 5: 367374. 


\section{Influence of Cultivation Conditions on the Production of Staphylocoagulase by Staphylococcus aureus 104}

High yields of staphylocoagulase from Staphylococcus aureus 104 were obtained in a simple salts medium supplemented with glycerol, casein hydrolysate and three vitamins. Conditions of oxygen-limitation (dissolved oxygen concentration $<2 \%$ ), a pH of $7 \cdot 4$, a temperature of $35^{\circ} \mathrm{C}$ and a 1 in 10 inoculum of overnight culture were required for optimal yields of staphylocoagulase.

\section{INTRODUCTION}

Staphylocoagulase is an extracellular protein produced by potentially pathogenic strains of Staphylococcus aurews. However, its precise role in the pathogenesis of infections due to $S$. aureus is not clear.

Several reports describe the partial purification of staphylocoagulase, but none of these preparations were of sufficient homogeneity to assess the mode of action of the enzyme (Blobel et al., 1960; Duthie \& Haughton, 1958; Jacherts, 1956; Jeljaszewicz, 1958; Murray \& Ghodes, 1960; Siwecka \& Jeljaszewicz, 1968; Soulier et al., 1967; Stutzenberger \& San Clemente, 1968; Tager, 1948; Zolli \& San Clemente, 1963). Bas et al. (1974) found that purified staphylocoagulase was a single-chain protein with a molecular weight of 61000 , an isoelectric point at $\mathrm{pH} 4.53$ and with aspartic acid as the $\mathrm{N}$-terminal amino acid. Hemker et al. (1975) reported that the activation of human prothrombin by staphylocoagulase occurred stoicheiometrically, one molecule of staphylocoagulase forming a complex with one of prothrombin without splitting the peptide bonds. Therefore the thrombin activity of this complex was probably not due to proteolytic breakdown of prothrombin to thrombin, but to a change of the tertiary structure of prothrombin that unmasked a thrombin-like active centre.

Various authors have described different conditions for optimal production of stapluylocoagulase, presumably due to variations in strains, media and cultivation conditions. Therefore a new investigation was undertaken to assess the effects of medium composition and environmental factors on the formation of staphylocoagulase by $S$. aureus 104 when grown in batch cultures. This strain was chosen because high yields of enzyme had been obtained with it (Bas of al. 1974: Soulier ef al., 1967).

\section{METHODS}

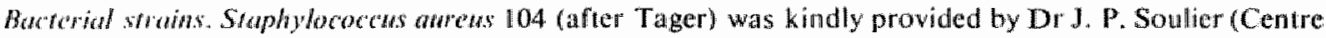
National de Transfusion Sanguine, Paris). Staphy fococcus aurews NCTC 8178 was from the National Collection of Type Cultures, London. Stock cultures were maintained on nutrient agar slants at 4 c and were subcultured monthly.

Cuhivarion media. Brain Heart Infusion (Difco) contained $37 \mathrm{mg} \mathrm{m}^{-1}$. Yeast extract medium contained a simple salts mixture described by Evans ef al. (1970) (omitting $\mathrm{NH}_{4} \mathrm{Cl}$ ) with a $\mathrm{Mg}^{2 i}$ concentration of $100 / \mathrm{m}$, 


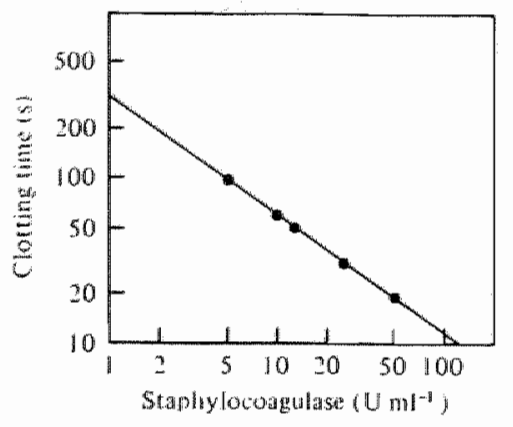

Fig. 1. Relation between clotting time and activity of crude staphylocoagulase.

supplemented with (per ml) $1 \mathrm{mg}$ glycerol and $20 \mathrm{mg}$ yeast extract (Difco). Casein hydrolysate medium contained the simple salis mixture of Evans et al. (1970) (omitting $\mathrm{NH}_{4} \mathrm{Cl}$ ) with a $\mathrm{Mg}^{2+}$ concentration of $100 / \mathrm{M}_{\mathrm{i}}$ supplemented with (per ml) $20 \mathrm{mg}$ Casamino acids (Difco), $1 \mathrm{mg}$ glycerol and $20 \mathrm{fl}$ vitamin solution. Symthetic medium contained the simple salts mixture of Evans et af. (1970) with a $\mathrm{Mg}^{2+}$ concentration of $100 / \mathrm{m} \mathrm{M}_{4}$ supplemented with (per ml) $1 \mathrm{mg}$ glycerol, $20 \mu \mathrm{l}$ vitamin solution and the following amino acids (mg): L-Asp, 0.76; L-Thr, 0.64; L-Ser, 1.12; L-Glu, 2.28; L-Pro, 0.32; L-Gly, 0-32; L-Ala, 1.16; L-(Cys). 0.16: L-Val, 104; I..Met, 0.32; L-1le, 0.84; L-Leu, 1.32; L-Tyr, 0.44; L-Phe, 1.36; L-Lys, 1.66; L-His, 0.28; L-Try, $0.20 ; \mathrm{L}$-A $\mathrm{Ag}, 0.68$. The vitamin solution contained (per ml double glass-distilled water) $300 / \mathrm{gg}$ thiamin, $100 / \mathrm{g}$ micotinic acid and $30 \mathrm{ng}$ biotin. This mixture was heat sterilized separately at $\mathrm{pH} 4.5$. The $\mathrm{pH}$ or all media was adjusted 107.4 .

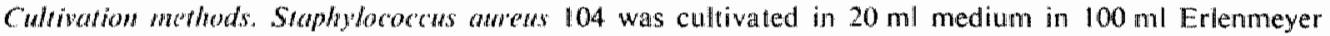
flasks at $35^{\circ} \mathrm{C}$. Some cultures were shaken in ayrotary waterbath $(\mathrm{G}-76$, New Brunswick $)$ at $190 \mathrm{rev}^{-m_{i n}{ }^{-1}}$ and a displacement of $13 \mathrm{~mm}$. The acration efficiency in the shaken flasks, as determined by the sulphite oxidation method (Cooper ${ }^{\prime}(a / ., 1944)$, was less than 5 mmol $O_{w} \mathrm{I}^{-1} \mathrm{~h}^{-1}$.

The organism was also cultivated in stirred fermenters (Bioflo C 30 , New Brunswick), with a culture volume of 300 to $400 \mathrm{ml}$, depending on the stirrer speed. No baffles were used. Air was flushed over the culture surface at a rate of $300 \mathrm{ml} \mathrm{min} \mathrm{n}^{-1}$. The aeration efficiency, determined by the sulphite oxidation method (Cooper et al. 1944), was less than $5 \mathrm{mmol} \mathrm{O} \mathrm{O}^{-1} \mathrm{~h}^{-1}$ at stirrer speeds lower than $400 \mathrm{rev}$. min ${ }^{-1}$. The dissolved oxygen concentration was less than $2 \%$ at speeds lower than 400 rev. min-1 ${ }^{-1}$. The pH was maintained constant at $7 \cdot 4$ by automatic addition of $2 \mathrm{M}-\mathrm{KOH}$. The temperature was held at $35^{\circ} \mathrm{C}$.

Sraply focoagukase assay. The staphylocoagulase activity was determined on the basis of the clotting time obuatined when $0.1 \mathrm{ml}$ culture supernatant (1/ $\mathrm{ml}$ culture was centrifuged at $12500 \mathrm{~g}$ for $2 \mathrm{~min}$ ) was mixed with $0.1 \mathrm{mll}$ rabbit platsmat and incubated at $37^{\circ} \mathrm{C}$ (Soulier ef al., 1967). The amount of staphylocoagulase was cilculated from a reference curve constructed from clotting times obtained with dilutions (in Michaelis buther of a pool of 10 crude staphylocoagulase preparations. This pool was considered to contain 1000 arbitrary units (U) ml" (Fig. I).

Properation of crule sophylocongulase. Crude staphylocoagulase was prepared by a modification of the

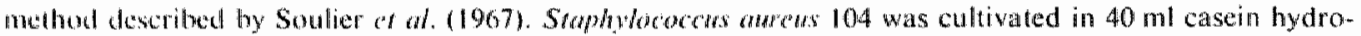
lystic medium in $200 \mathrm{ml}$ Erlenmeyer llasks in $35^{\circ} \mathrm{C} \mathrm{C}$ without shaking. After $24 \mathrm{~h}$ the cullures were centrifuged for $30 \mathrm{~min}$ at $15380 \mathrm{~g}$; the supernatant was brought to $\mathrm{pH} 3.5$ with $3 \mathrm{M}-\mathrm{HCl}$ and left for $18 \mathrm{~h}$ at 0 " C. The precipitate was collected by centrifugation for $30 \mathrm{~min}$ at $7000 \mathrm{~g}$, washed once with $0.15 \mathrm{~m}$-5odium acetate bulfer ( $\mathrm{pH} 3.8$ ), dissolved in $0.15 \mathrm{M}-\mathrm{NaCl}$ and brought to $\mathrm{pH} 7.4$ with $\mathrm{NaOH}$.

Staphylocoagulase production is defined here as net production, i.e. the enzyme synthesized by some or all of the bacterial cells plus its release from the living or dead cells minus any inhibition or destruction outside the cell.

\section{RESULTS AND DISCUSSION}

To simplify the procedure for purification of staphylocoagulase produced by $S$. aureus 104, it was necessary to replace the Brain Heart Infusion medium that is generally used by a more defined medium. The major disadvantage of Brain Heart Infusion is its high lipid content that necessitates a very time-consuming lipid-extraction step in the purification procedure (Bas et al., 1974).

The amounts of staphylocoagulase produced in various media are shown in Table $\mathbb{\|}$. The 


\section{Table 1. Staphlocoagulase production by Staphylococcus aureas 104 in warious whedia}

lirlenmeyer flasks ( $100 \mathrm{ml}$ ) containing $20 \mathrm{ml}$ medium were inoculated with $2 \mathrm{ml}$ ovemight culture and cultwated at $35^{\circ} \mathrm{C}$ without shaking or with shaking at $190 \mathrm{rev}$ min'. After 18 h. staphylocoagulase and absorbance at $540 \mathrm{~nm}$ (figures in parentheses) were determined.

\begin{tabular}{|c|c|c|}
\hline \multirow[b]{2}{*}{ Medium } & \multicolumn{2}{|c|}{ Slaphylocoagulase (U ml ') } \\
\hline & Static culture & Shaken culture \\
\hline Brain Heart Infusion & $1.3(6 \cdot 29)$ & $24(11 \cdot 69)$ \\
\hline Yeast extract medium & $21(4 \cdot 24)$ & $7(11.75)$ \\
\hline Casein hydrolysate medium & $65(4 \cdot 73)$ & $17(9.53)$ \\
\hline Casein hydrolysale (vitamin-free) medium & $10(5 \cdot 05)$ & $<1(8 \cdot 77)$ \\
\hline Synthetic medium & $42(6.53)$ & $5(9 \cdot 68)$ \\
\hline
\end{tabular}

shaken cultures, except those in Brain Heart Infusion, produced less staphylocoagulase than did the static cultures. Several authors (Duthie \& Haughton, 1958: Fahlberg \& Marston, 1960; Stutzenberger \& San Clemente, 1968; Tager, 1948) have reported that agitation is essential for the production of large amounts of staphylocoagulase. Soulier of al. (1967) found that static cultures of $S$. aureus 104 in Brain Heart Infusion produced $15 \mathrm{U} \mathrm{ml}^{-1}$ (11 Roux bottles containing $200 \mathrm{ml}$ medium).

The reason for the diminished staphylocoagulase production obtained with cultures grown in the casein hydrolysate medium based on vitamin-free Casamino acids rather than Casamino acids is obscure. Addition of different mixtures of vitamins (up to 12) gave no increase in staphylocoagulase production. Further, investigations regarding the composition and preparation of the Difco products used failed to reveal the cause of the difference in yields.

A synthetic medium for $S$. aurcus 104 has not been described previously, a though Marston \& Fahlberg (1960) described a synthetic medium suitable for $S$. aurcus NCTC 8178 . In our hands, neither $S$. aureus 104 nor NCTC 8178 produced any staphylocoagulase in this medium (data not shown). However, with the synthetic medium described here, both $S$. arrews 104 and NCTC 8178 (the latter grown with agitation) produced considerable amounts of staphylocoagulase ( 65 and $40 \mathrm{U} \mathrm{ml}^{-1}$, respectively).

Staphylocoagulase was produced optimally $\left(120 \mathrm{U} \mathrm{ml}{ }^{1}\right)$ in medium containing $5^{\prime \prime}(w / v)$ casein hydrolysate. The $\mathrm{Mg}^{2+}$ concentration was critical for staphylocoagulase production. being optimal at 50 to $100 / 1 \mathrm{M}$ : higher concentrations were inhibitory. Glycerol (and glucose) concentrations higher than $0.2^{\circ}$ " $(w / v)$ also inthibited staphylocoagulase production. Addition of bovine serum albumin (up to $1 \%, w / v)$, previously considered necessary to obtain high staphylocoagulase yields (Altenbern, 1966), failed to give any enhancement. For staphylocoagulase purification, the casein hydrolysate medium was chosen for bulk production. For physiological studies (particularly continuous culture studies), the synthetic medium and the casein hydrolysate medium seemed the most promising since both media are ree of lipid and protein. Removal of any of the amino acids from the synthetic medium reduced the amount of staphylocoagulase produced.

In all the media listed in Table I. staphylocoagulase production occurred only in the cxponential growth phase. Optimal amounts of enzyme were obtained with an initial pH of 7.4, an incubation temperature of $35^{\circ} \mathrm{C}$ and a 1 in 10 inoculum of overnight culture.

The complex nature of the regulation of staphylocoagulase production is illustrated by Fig. 2. In agituted yeast extract medium, production of staphylocoagulase by $S$. atritus 104 reached a maximum after 1.5 th and then declined rapidly. If shaking was stopped $1.5 \mathrm{~h}$ after inowation, the staphylocoagulase level still declined, but after several hours synthesis restarted. When the experiment shown in Fig. 2 was repeated in stirred fermenters, the decrease in staphylocoagulase level (from 18 to $4 \mathrm{U} \mathrm{m}^{\prime \prime}$ ) at $300 \mathrm{rew}$. min "' was atcompanied by a decrease in $\mathrm{pH}($ to $\mathrm{pH} 5 \cdot 5)$. When grow th continued, the $\mathrm{pH}$ rose to 8 to 8.5 and staphylo- 


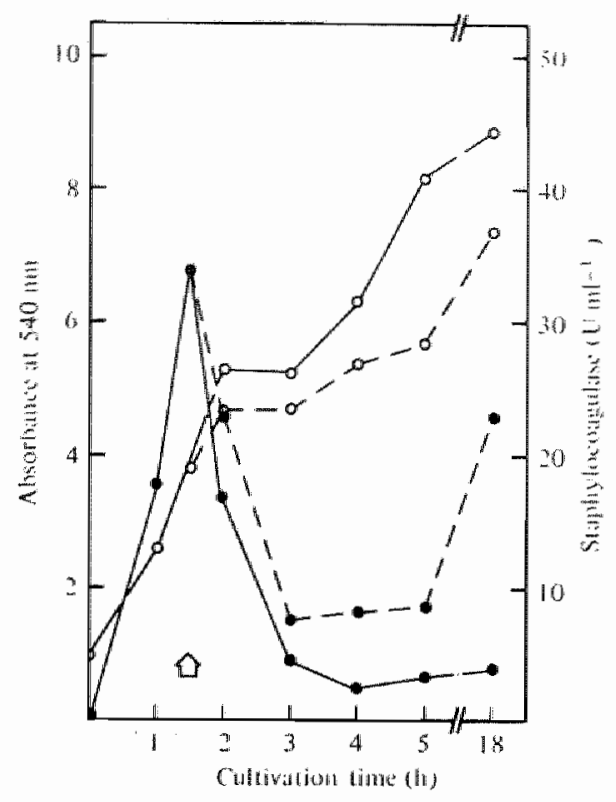

Fig. 2. Staphylocoagulase production by Staphylococcus aureus 104 as a function of the cullevation time. Four Erlenmeyer flasks ( $100 \mathrm{mll}$ ), each containing $20 \mathrm{ml}$ yeast extract medium, were inoculated with $2 \mathrm{ml}$ overnight culture and incubated at $35^{\circ} \mathrm{C}$ and $190 \mathrm{rev}$. min ${ }^{-1}$. After $1.5 \mathrm{~h}$, as marked by the arrow, two flasks were transferred to a non-shaking waterbath at $35^{\circ} \mathrm{C}$ and the experiment was continued. --.-. Static cultures; - - , shaken cultures; - , staphylocoagulase; $O$, absorbance at $540 \mathrm{~nm}$.

\section{Table 2. Staphy/ocoagulase production by Staphylococcus aureus 104}

Yeast extract medium $(20 \mathrm{ml})$ was inoculated with $2 \mathrm{ml}$ overnight culture and shaken at 190 rev. $\min ^{-1}$ at $35^{\circ} \mathrm{C}$. After $1.5 \mathrm{~h}_{8}$ the culture was centrifuged at $5000 \mathrm{~g}$ for 15 min. The supernatant contained $27 \mathrm{U}$ staphylocoagulase $\mathrm{ml}^{-1}$. Sediment and supernatant were then incubated in various mixtures (as indicated) and staphylocoagulase production in these mixtures was determined after a further $1.5 \mathrm{~h}$.

Incubation mixture

Control: culture not centrifuged

Sediment $+20 \mathrm{ml}$ supernatant

Sediment $+20 \mathrm{mll}$ fresh yeast extract medium

$2 \mathrm{ml}$ Overnight culture $+18 \mathrm{ml}$ supernatant
Staphylacoagulase production $\left(\mathrm{U} \mathrm{ml}^{-1}\right)$

$$
\begin{gathered}
-16 \\
-16 \\
0.5 \\
17
\end{gathered}
$$

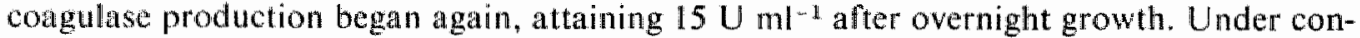
ditions in which the pH was maintained at $7 \cdot 4$, there was little reduction in staphylocoagulase levels $\left(8 \mathrm{U} \mathrm{ml}^{-11}\right.$ at $200 \mathrm{rev} \cdot \mathrm{min}^{-1}$, remaining constant during $18 \mathrm{~h}$ cultivation; $18 \mathrm{U} \mathrm{ml}^{-1}$ at $300 \mathrm{rev}$. min ${ }^{-1}$, decreasing during $18 \mathrm{~h}$ cultivation to $16 \mathrm{U} \mathrm{m}^{-1}$ ). Similar observations were made by Duthie \& Haughton (1958) for S. atureus NCTC 8178 growing in a casein hydrolysate medium. They found that the amount of staphylocoagulase reached a maximum 80 min after inoculation, and then decreased rapidly. The maximum level of staphylocoagulase under the conditions of Fig. 2 was strongly dependent on the inoculum size. Optimal staphylocoagulase production $\left(42 \mathrm{U} \mathrm{ml}^{-1}\right)$ occurred with a 1 in 10 inoculum.

The experiment shown in Table 2 indicated that the reduction in staphylocoagulase production is probably not due to exhaustion of medium constituents or production of an inhibitory substance. Moreover, regardless of the growth phase, proteolytic activity was never demonstrated in the culture supernatants.

Similar findings were obtained when $S$. aureus 104 was subcultured in shaken flasks 


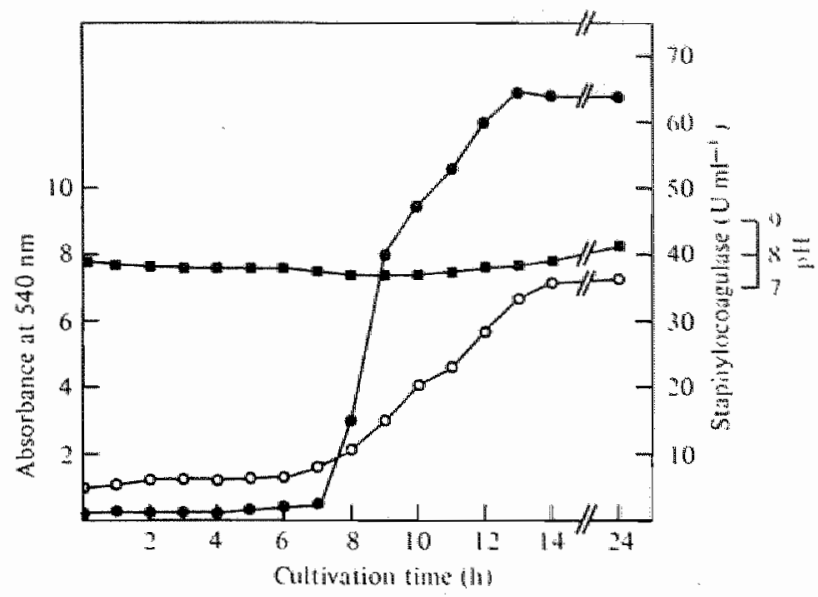

Fig. 3. Staphylocoagulase production by Sraphylococcus aureas 104 as a function of the cultivation time. Thirty-two Erlenmeyer flasks ( $100 \mathrm{ml}$ ), each containing $20 \mathrm{ml}$ casein hydrolysate medium, were inoculated with $2 \mathrm{ml}$ overnight culture and incubated at $35^{\circ} \mathrm{C}$ without agitation. Every hour, absorbance at $540 \mathrm{~nm}(0)$, staphylocoagulase $(O)$ and $\mathrm{pH}(\theta)$ wete determined in two flasks.

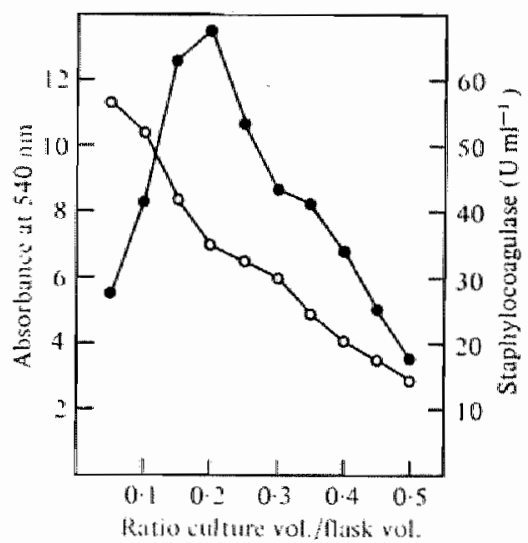

Fig. 4. Influence of the ratio culture volume/flask vollume on staphylocoagulase production by Staphylococcus aureus 104 . Erlenmeyer flasks $(100 \mathrm{ml})$ containing various volumes of casein hydrolysate medium and a $l$ in 10 inoculum of overnight culture were incubated at $35^{\circ} \mathrm{C}$ without agitation. After $18 \mathrm{~h}$, absorbance at $540 \mathrm{~nm}(0)$ and staphylocoagulase (C) were determined.

containing casein hydrolysate or yeast extract medium. After two subcultures, production of staphylocoagulase ceased completely and remained at zero during 14 further subcultures; but when the culture was subcultured to casein hydrolysate or yeast extract medium and incubated statically, staphylocoagulase production began again and regained its full potential after 2 to 3 subcultures. When $S$, aureus 104 was subcultured up to 14 times in casein hydrolysate or yeast extract medium incubated statically, production of staphylocoagulase remained high. The loss of ability of staphylococci to produce staphylocoagulase, deseribed by Tager (1974), is evidently dependent on the cultivation conditions.

The production of staphylocoagulase in casein hydrolysate medium at different growth phases is shown in Fig. 3. After a prolonged lag phase, rapid growth was accompanied by production of the enzyme. When growth ceased, there was no further change in staphylocoagulase level. The $\mathrm{pH}$ remained practically constant, which is an important factor in optimal staphylocoagulase production. 
That agitation and inoculum size infuence staphylocoagulase production so markedly suggests that aeration efficiency is important. Thus staphylocoagulase production takes place only when the aeration efficiency is less than a critical value, as indicated by the experiment shown in Fig. 4. The maximum production is related to the final culture density, because at a medium volume/fask volume ratio higher than $0 \cdot 2$, both production of staphylocoagulase and cell density decrease, indicating that the amount of staphylocoagulase produced per cell is approximately constant.

Oxygen measurements made with a Clark electrode during growth of 5 . aureus 104 in casein hydrolysate medium without agitation revealed that in the lag phase the dissolved oxygen concentration was less than $2 \%$. Redox potential measurements (which also give an indication of the oxygen concentration) with a platinum and a calomel electrode indicated that the redox potential of the culture decreased rapidly during the first $2 \mathrm{~h}$ cultivation. from $+400 \mathrm{mV}$ to $+100 \mathrm{mV}$, and then continued to decrease steadily for the next 21 h to $-80 \mathrm{mV}$. Staphylocoagulase was produced at redox potentials between +40 and $+60 \mathrm{mV}$. i.e. during a period of considerable oxygen-limitation. For other extracellular enzymes (phosphatase, staphylokinase, enterotoxin A, nuclease) oxygen-limiting conditions are also necessary for high amounts of enzyme to be formed (Arvidson ef al, 1976: Carpenter \& Silverman, 1976).

Although it is apparent that oxygen plays a major role in staphylocoagulase production by $S$. aureus 104, other factors are involved, such as $\mathrm{pH}$, growth rate and nutrient-limitation, which need to be studied further. Experiments concerning the influence of these factors might usefully employ continuous culture techniques. However, the possibility remains that staphylocoagulase production by $S$. aureus 104 is a transient-state and not a steady-state phenomenon, so that continuous culture may not be applicable.

It is not clear whether staphylocoagulase is a true exo-enzyme. Indeed only low levels of the enzyme can be demonstrated in cell lysates of $S$. aureus 104 [prepared with lysostaphin, see also Altenbern (1966)], but the possibility that a high percentage of lysis occurs during growth cannot be excluded. Extracellular RNA and DNA, released during lysis, cannot be demonstrated because $S$. aurews 104 also produces high levels of a nuclease which breaks down RNA and DNA. Moreover, Blobel \& Berman (1960) demonstrated that staphylocoagulase is also located on the cell surface. Thererore growth conditions that result in unstable walls might be favourable for high levels of staphylocoagulase. The non-specific stimulatory effect ol serum albumin as described by Altenbern (1966), and the influence of the $\mathrm{Mg}^{2+}$ concentration on staphylocoagulase production, indicate that the wall composition nuay well play an important role.

We wish to thank Dr O. N. Neijssel for helpful discussions and Professor D. W. Tempest for critically reading the manuscript.

\section{REFERENCES}

A.LTENGER N, R. A. (1966). On the nature of albuminpromoted coagulase release by Staphylococcus aurens. Journal of Infecrious Diseases 116 , $593-600$.

Arvidson, S., BIÓRK1IND, A., ERIKSSON, R. \& Holme, T. (1976). Enzymes from Sraphylococcus

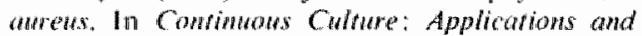
New Fieldr, vol. 6, pp. 238 - 250. Edited by A. C, R. Dean, D. C. Huwood, C. G. T. Evams \& J. Melling. Chichester : Ellis Horwood.

B.AS, B. M. MULler, A. D. \& HAMkr, H. C. (1974). Parification and propenties of staphylocoagulase.

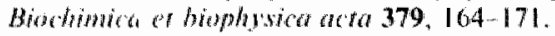

Bitumit, H. \& Btrman, D. T. (1960). Serologic studies of purified staphylococcal coagulase with special reference to fluorescence microscopy. Journal of lonmunology $85,244-249$.

Blobel, H., Berman, D. T. \& Simon, J (1960). Purification of staphylococcal coggulase. fowmen of Bacteriology 79, 807-815.

Carpenter, D. F. D. SilvermaN, G. J. (1976). Synthesis of staphylococcal enterotoxin $A$ and nuclease under controlled fermentor conditions. Applied and Enwinamental Microblolosy $31,24,248$.

Coopler, C. M. Fernstrom, G. A. \& Millik. S. A. (1944). Performance of agitated gas liquid con-

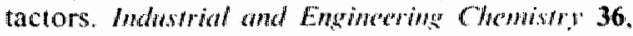
$504-509$. 
Duthit, E.S. \& Hachtion, G. (1958). Purification of free staphylococcal coagulase. Biochemical Anowal 70, 125-134.

EVANG, C.G.T., HERBERT, D. \& TEMPEST, D. W. (1970). The continuous cultivation of microorganisms. 11. Construction of a chemostat. Methods in Microbiology, 2, 277-328.

FAHLGERG, W. J. \& MARSton, J. (1960). Coagulase production by Staphylococcus auteus. I. Factors influencing coagulase production. Jownal of Infectious Diseases 106, 11.1-115.

HeMkeR, H. C., BAS, B. M. \& MUller, A "D. (1975). Activation of a pro-enzyme by a stoichiometric revetion with another protein. The reaction beween prothrombin and staphylocoagulase. Biochimica ed biophysica acta 379, 180 -188.

JACHERT: D. (1956). Zur Reindarstellung der Staphylokokken Coagulase. Zeitschrift fur Hygriene. Medizinische Mikrobiologie, Immunologie und Wrologie 142, 213-218.

JeLASZEwICZ, J. (1958). Studies on staphylococcal coagulases. Acta microbiologira polowia 7. 17-34.

Marston. J. \& Fahllberg, J. (1960). Coagulase production by Staphydacocous aureus. II. Growth and coagulase production in complex and chemically defined mediums - comparison of chemically defined mediums, Jomnal of Infecrions Diseases 106. $116-122$.
Murkay, M. G Gmodes, P. (1960). Punification off

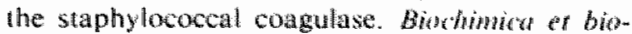
physica aria 40, 518-522.

SINECKA, M. \& JELASzEMICZ, J. (1968). Purification of staphylocoaguhase and some of its properties. Zentrablant fur Bakrerialagie, Parasinen-

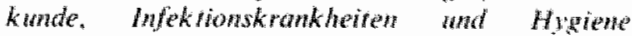
(Abreilurg $l$, Originale A) 208, 385-394.

Soulder, J. P." Lewh. S., PANTY, A. M. \& PaouWartelle. O. (1967). Preparation, concentration et étallonnage de la staphylocoagulase. Revwe francaise d"eudes rimiques er brologiques 12, 544 558.

Stutzenberger, F. J. \& San Clemente, C.L. (1968). Production and purification of staphylococcic coagulase in a semi-defined medium. American Jownat of Veferinary Research 29, $1109-1116$.

TAGER, M. (1948). Concentration, parial purifleation, properties and nature of staphylocoagulase. Jowrmal of Biological Medicine 20, 487-501.

TAGER, M. (1974). Cuprent views on the mechanism of coagulase action in blood clorting. Amals of the New Yowk Acadery of Sciences $236,277-291$.

Zolla, Z. \& San Clamente, C. L. (1963). Purification and characterization of staphylocongulase. Jowmal of Bacteriology 86, 527 535 


\section{Continuous culture studies on the production of staphylocoagulase by Staphylococcus aureus}

Engels, W. Kamps, M. A. F. and van Boven, C. P. A. 1980. Continuous culture studies on the production of staphylocoagulase by Staphylococcus aureus. Antonie van Leeuwenhoek 46:533 550 .

The production of staphylocoagulase was studied with continuous cultures of various $S$. aureus strains in a simple salts medium supplemented with mannitol, casein hydrolysate and three vitamins. Conditions of low oxygen avallability and magnesium-limitation were required for optimal steady-state staphylocoagulase production. It was demonstrated that the specific rate of staphylocoagulase production was dependent on the growth rate.

In two bovine strains, the production rate pattern was similar to that of an inducible enzyme sensitive to catabolite repression, although no specific inductor or repressor could be demonstrated. The human strain, on the other hand, produced staphylocoagulase constitutively. In all strains the specific rate of production of total extracellular protein was strictly proportional to the growth rate. The bovine strains produced 6 times more staphylocoagulase in chemostat culture as compared with batch cultures of the same organisms.

It is likely that mannitol functioned as an energy source rather than as a carbon source because it was converted for a major part to acetate and for a minor part to lactate and not to new cell material. Repression of staphylocoagulase production by mannitol, acetate or lactate was not observed. The probable nature of the regulating mechanism(s) underlying staphylocoagulase production is discussed.

\section{INTRODUCTION}

The production of the various exoenzymes and exotoxins by Shaphlococrus atrows has been investigated extensively in batch cultures, but applications of continuous culture techniques in these studies have not been widespread (Arvidson. Holme and Wadström, 1970: Arvidson et al., 1976; Holme and Arvidson. 1976; Holme and Wadström. 1971; Jarvis, Laurence and Pritchard, 1975). In particular the influence of cultivation conditions on the production of staphylo- 
coagulase by $S$. aureus in chemostat cultures has, as far as we know, not been studied before.

It was previously shown (Engels, Kamps and van Boven, 1978) that S. aureus strain 104, in batch cultures, produced optimal amounts of staphylocoagulase under oxygen-limited growth conditions. Moreover, it was demonstrated that the concentrations of the sources of magnesium and carbon were also critically important. Therefore, a study was undertaken to investigate the effect of these parameters and of the growth rate on the production of staphylocoagulase in $S$. aureus strain 104 and two bovine wild type strains under steady-state growth conditions.

In this way more information about the role of staphylocoagulase in pathogenesis might be obtained because also in its host. $S$. aureus will grow with submaximal growth rates and under substrate-limited growth conditions.

The results of these studies are reported in the present paper.

\section{Materials and Methods}

\section{Orgamisms}

Staphylococcus aureus strains (for characteristics see Table 1) were maintained

Table 1. Characteristics of the Staphylococcus aureus strains.

\begin{tabular}{|c|c|c|c|}
\hline \multirow[t]{2}{*}{ Source } & \multicolumn{3}{|l|}{ Straitit } \\
\hline & 20, bovine & 15. bovine & 104. human ${ }^{2}$ \\
\hline \multicolumn{4}{|c|}{$\begin{array}{l}\text { Staphylocongulase reaction } \\
\text { with: }\end{array}$} \\
\hline human plasmand & +4 & + & + \\
\hline rubbit plasma & $\#$ & + & + \\
\hline bovino plasme & 4 & - & - \\
\hline DNase & + & + & + \\
\hline Proleas & - & - & - \\
\hline Phosphastase & + & + & + \\
\hline Tween 80 hydralysis & - & - & + \\
\hline Haemolysins & + & $\sharp$ & + \\
\hline Suphylokinase & - & - & + \\
\hline Penicillinase & + & + & - \\
\hline Cryslal violet reaction & $\mathrm{A} / \mathrm{B}$ & B & $\mathrm{C} D$ \\
\hline Phage type & 1, HI bovine set & 1, HI, bovine set & III \\
\hline Pigment & yellow & yellow & yellow \\
\hline
\end{tabular}

These strains had been selected from 261 S. aureus strains provided by Dr J. M. F. Seas (Animall Health Centre, Heythuizen, The Netherlands).

${ }^{2}$ S. aurets 104 was kindly provided by Dr J. P. Soulier (Centre National de Transfusion Sanguino. (aris). 
on nutrient agar slopes by monthly subculture. $S$. aureus strain 20 and 15 were characterized as bovine types on the basis of phage type and crystal violet reaction (Szulga et al., 1976). However, the staphylocoagulase activity of strain 20 with human and rabbit plasma was five to ten times higher than with bovine plasma, whereas staphylocoagulase produced by strain 15. did not react with bovine plasma at all.

\section{Growth conditions}

Organisms were cultivated in Bioflo C30 chemostats (New Brunswick Scientific Co. Inc., New Brunswick, N.J., U.S.A.) in a casein hydrolysate medium containing a simple salts mixture described by Evans, Herbert and Tempest (1970) (omitting $\mathrm{NH}_{4} \mathrm{Cl}$ ) with a $\mathrm{Mg}^{2}$ concentration of $100 \mu \mathrm{M}$, supplemented with (per liter) $10 \mathrm{~g}$ Casamino acids (Difco), $2 \mathrm{~g}$ mannitol, $6 \mathrm{mg}$ thiamin, $2 \mathrm{mg}$ nicotinic acid and $0.6 \mu \mathrm{g}$ biotin. The culture volume was $300-350 \mathrm{~mm}$, depending on the stirrer speed. The $\mathrm{pH}$ was maintained at a value of 7.4 by means of an automatic titrator with $2 \mathrm{M} \mathrm{KOH}$ as the titrant. The temperature was held at $30 \mathrm{C}$.

To minimize excessive foaming the balfles had to be removed. the impeller speed kept at moderate values and air flushed over the surface $(300 \mathrm{ml} / \mathrm{min})$. Nevertheless, an antifoaming agent was still necessary and was added automatically at regular time intervals. The AF-antifoam (purchased from Dow Corning), added as a $2 \%(w / v)$ solution, suppressed effectively foam formation by the bovine strains: in case of strain 104, such high dosages of this antifoam had to be added that staphylocoagulase production was strongly inhibited (see also Jarvis et al., 1973). The same phenomenon was observed with polypropylene glycol P2000. Therefore, another antifoaming agent on silicone base (purchased from $\mathrm{BDH}$ ) was used, which had a high effectivity and could be added at a noninhibitory concentration of $0.5 \%(\mathrm{w} / \mathrm{v})$.

\section{Analyrical methods}

Bacterial dry weight was measured by the procedure of Herbert. Phipps and Strange (1971).

Total extracellular protein was determined, after overnight dialysis of culture supernatant against double glass distilled water at $0-4 \mathrm{C}$, according to Lowry ed al. (1951).

Dissolved oxygen concentrations (D.O.C.) were measured with a Clark oxygen probe (type YSI 4004, Yellow Spring Instrument Co., Yellow Springs, U.S.A.). The electrode was sterilized with ethanol formaldehyde (1:1) vapour. In all experiments the D.O.C. measured in this way was $0-1 \%$ except when indicated otherwise.

Mannitol was determined according to Dawes, McGill and Midley (1971).

Acetate was assayed enzymically by the method of Holz and Bergmeyer (1974). 
L-Lactate was assayed with L-Lactate dehydrogenase by the method of Gutmann and Wahlefeld (1974).

D-Lactate was assayed with D-Lactate dehydrogenase by the method of Gawehn and Bergmeyer (1974).

Acetoin was determined according to Westerfeld (1945).

Magnesium was measured with an atomic absorption spectrophometer, Perkin-Elmer type 305B. In all experiments the $\mathrm{Mg}^{2+}$ concentrations in the culture fluid were in the range of 5-7 $\mu \mathrm{m}$ except when indicated otherwise.

Amino acid composition of culture supernatants and medium was analyzed with an automatic amino acid analyser (Locarte, London, U.K.).

Gas analysis. Oxygen consumed, and carbon dioxide produced by the cultures were determined by passing the dried effluent gas from the fermentor through an oxygen analyser (Taylor Servomex Type 0A 272, Crowborough. Sussex, England) and a carbon dioxide analyser (model IRGA 10, Grubb Parsons \& Co. Ltd., Walkergate, Newcastle upon Tyne, England). Prior to each determination, the analysers were calibrated with a standard gas mixture obtained from Hoek Loos (Amsterdam, The Netherlands).

P.P.S.B., (Prothrombin, Proconvertin, Stuart-Prower factor, antihaemophilic factor B), a concentrate of the blood clotting factors II, VII, X and IX was prepared according to Soulier et al. (1969) and kindly provided by Miss A. D. Muller, Dept. of Biochemistry, State University of Limburg.

Staphylocoagulase. A more direct and quantitative spectrophotometric assay was developed because in the "classic" clotting assay false positive or negative results can be obtained due to other extracellular products present in cultures of S. aureus (Wegrzynowiczet al., 1979). Moreover, clotting times are very difficult: to standardize. Staphylocoagulase activity was assayed by a modification of the method described by Kirchhof, Vermeer and Hemker (1978) originally used for the determination of thrombin activity. The reaction mixture $(600 \mu \mathrm{\mu l})$ contained 20. $100 \mu \mathrm{l}$ culture supernatant. $72 \mathrm{~mm}$ triethanolamine buffer $\mathrm{pH} 8.4 .144 \mathrm{~mm}$ $\mathrm{NaCl} .166 \mu \mathrm{m}$ Chromozym TH (Boehringer. Mannheim) and $0.002 \mathrm{ml}$ human P.P.S.B. solution, containing $1.9 \mathrm{mg}$ prothrombin/ml. as the prothrombin source. One unit was defined as the amount of enzyme giving an increase in absorbance at $405 \mathrm{~nm}$ of 1.0 per $\mathrm{min}$ at $37 \mathrm{C}$. Because proteolytic activity was not detected in absence of prothrombin and no proteolytic enzymes in the culture supernatants could be demonstrated. it can be concluded that staphylocoagulase activity was measured specifically. Staphylocoagulase production by S. aureus strains was also screened on agar plates containing $52 \mathrm{mg} / \mathrm{ml}$ Brain Heart Infusion agar (Difco) and 10\%(v/v) human plasma. Staphylocoagulase producing colonies were surrounded by haloes of $4-7 \mathrm{~mm}$ in diameter after $18 \mathrm{~h}$ of cultivation at $37^{\circ} \mathrm{C}$.

Penicillinase was assayed by the method of Sargent (1968).

DNase was assayed according to Heins, Taniuchi and Anfinsen (1966).

Phosphatase was assayed according to Ghosh. Wouters and Lampen (1971). 
To a reaction mixture $(1 \mathrm{ml})$ containing $50 \mathrm{~mm}$ Tris- $\mathrm{HCl} \mathrm{pH} 7.4,0.5 \mathrm{mM} \mathrm{MgCl} \mathrm{Mg}_{2}$ and $5.5 \mathrm{~mm}$ sodium-p-nitrophenylphosphate, $0.1 \mathrm{ml}$ culture supernatant was added. After $30 \mathrm{~min}$ of incubation at $37^{\circ} \mathrm{C}$, the reaction was terminated by adding $10 \mathrm{ml} 0.02 \mathrm{~m} \mathrm{NaOH}$. One unit was defined as the amount of enzyme giving an increase in absorbance at $405 \mathrm{~nm}$ of 5 .

Protease was determined with the Azocoll method (Calbiochem) according to Aronson, Angelo and Holt (1971). The absorbance was measured at $520 \mathrm{~nm}$.

L-Lactate dehydrogenase and D-Lactate dehydrogenase were assayed according to Bergmeyer and Bernt (1974) with L-lactate and D-lactate as substrate. respectively.

Haemolysis, Crystal violet-test, Tween 80-hydrolysis, Staphylokinase, and phage typing were carried out by the National Institute of Public Health (R.I.V., Bilthoven, The Netherlands) according to Meyer (1967).

Lysozyme was assayed according to Shugar (1952).

\section{RESULTS}

Staphylocoagulase production by S. aureus strain 20

Chemostat cultures of $S$. aureus strain 20 were set up and the effect of various environmental parameters on the production of staphylocoagulase by this strain was studied. The medium was composed so as to provide a magnesium limitation and the aeration efficiency of the culture vessel was diminished to limit deliberately the availability of oxygen.

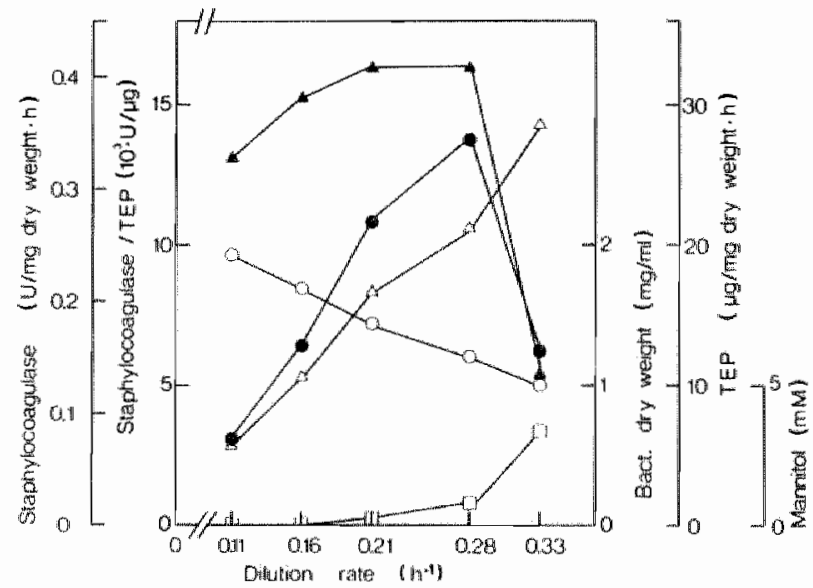

Fig. I. Intluence of dilution rate on the specific rates of production of staphylocoagulatse and total extracellular protein. and on the production of biomass in at chemostat culture of $S$. carrews $\operatorname{strain} 20$ $(400 \mathrm{cpm}, 30 \mathrm{C})$

Bacterial dry weight: - staphylocoagulase: $\triangle$ total extracellular protein (TEP): A ratio staphylocoaguliase total extracellular protein: $\square$ mannitol concentration in the culture fluid 
Table 2. Infuence of the mannitol concentration on the production of staphylocougufiase in :

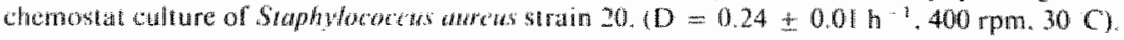

\begin{tabular}{|c|c|c|c|c|}
\hline & \multicolumn{4}{|c|}{ Mannitol concentration in the medium reserwoir (mm) } \\
\hline & 0 & $11^{1}$ & 22 & 44 \\
\hline Bacterial dry weight (mg/ml) & 1.64 & 2.00 & 2.08 & 2.17 \\
\hline Mannitol in culture fluid (mu) & 0 & 0.66 & 6.6 & 28.6 \\
\hline Staphylocoagulase (U/mg dry wl) & 0.19 & 0.64 & 0.63 & 0.61 \\
\hline Total extratcellular protein $(\mu \mathrm{g} / \mathrm{mg}$ dry wi) & 57 & 65 & 84 & 76 \\
\hline l.-Laclate (min) & 0.15 & 0.20 & 0.22 & 0.22 \\
\hline Acelate (mos) & 0 & 20.0 & 26.5 & 21.7 \\
\hline
\end{tabular}

"Routinely a concentration of $\| 1$ mm mannitol is used (see Materials and Methods).

The lirst series of experiments were performed to study the effect of the dilution rate of the culture on the production of staphylocoagulase. Fig. I shows that the specific rate of production of this protein increased with the dilution rate up to $\mathrm{D}=0.28 \mathrm{~h}^{-1}\left(\mu_{\max }=0.81 .0 \mathrm{~h}^{-1}\right)$; a further increase of the dilution rate resulted in a substantially lower specific production rate. The production of staphylocoagulase did not follow the pattern of extracellular protein production: at a dilution rate of $0.33 \mathrm{~h}$ - ' the ratio staphylocoagulase/total extracellular protein was lower by a factor of 3 as compared with those of the lower dilution rates. Nevertheless, the amount of staphylocoagulase produced in chemostat culture by this strain was approximately six times higher than that generally found in batch cultures of this organism $(0.6 \mathrm{U} / \mathrm{mg}$ is. $0.1 \mathrm{U} / \mathrm{mg})$.

It has to be mentioned that steady-states were attained relatively slowly. It took at least 810 changes of culture volume before a new steady-state was established. This phenomenon is most likely related to the nature of the growth limitation: in a number of cases it has been observed by other authors (Kurowski. Fensom and Pirt, 1973; Neijssel and Tempest, 1979) that magnesiumlimited chemostat cultures were very difficult to maintain at a steady-state.

II was of interest to determine whether staphylocoagulase production was due to cell-lysis. Therefore, we assayed the culture fluid for the presence of intracellualar enzymes. L- and D-lactate dehydrogenase could never be demonstrated. whereas high intracellular levels of these enzymes were present $(860$ and $440 \mathrm{mnoles} / \mathrm{min} \cdot \mathrm{mg}$ protein. respectively, at $\left.\mathrm{D}=0.28 \mathrm{~h}^{-1}\right)$. Lysozyme also could not be detected in the culture lluid, whereas high levels were found in the culture fluid of shaken-batch cultures (see also Arvidson ef al.. 1970). Therefore cell-lysis must hatve been minimal.

From Table 2, it can be concluded that mannitol is necessary for optimal staplyylocoagulase and biomass production. but that there is nocatabolite repres- 
sion at higher concentrations. In the absence of mannitol the production of staphylocoagulase decreased considerably, whereas no acetate is produced. It can be calculated that at mannitol concentrations of 11,22 and $44 \mathrm{~mm}$. mannitol is converted to acetate for 100,87 and $70 \%$, respectively. Since the accumulation of the acetate is also associated with increased staphylocoagulase production. the effect of addition of $10 \mathrm{~mm}$ acetate in the absence of mannitol was investigated. The major part of acetate was consumed $(8 \mathrm{~mm})$ : however. no increase of the staphylocoagulase and biomass production was observed (data not shown).

Another factor influencing staphylocoagulase production in batch cultures was the availability of oxygen (Engels et al., 1978). Because the baffles were removed from the fermentor vessel, the aeration efficiency could be influenced.

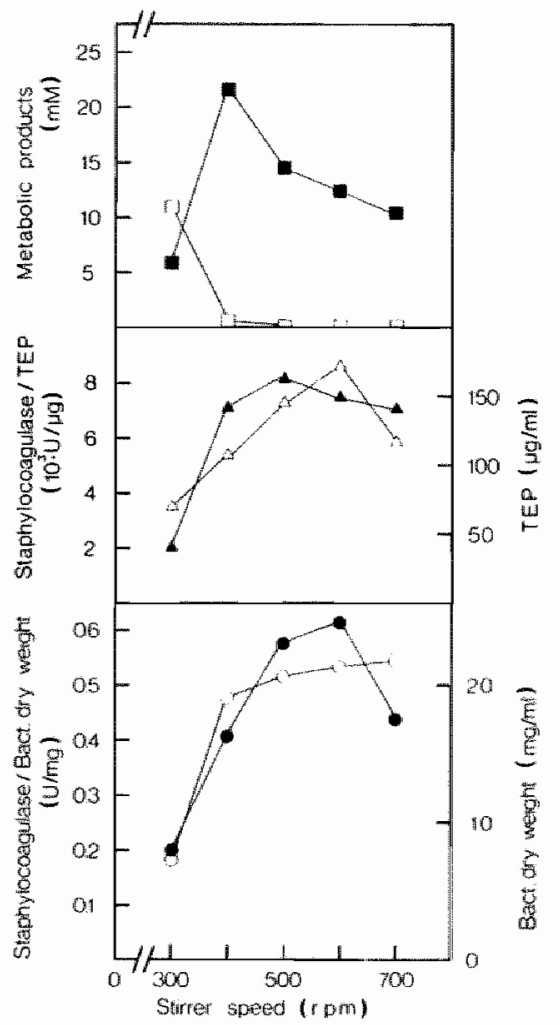

Fig. 2. Influence of the stirrer speed on the production of staphylocoagulase. total extratcellulatr protein, biomass, L-lactate and acetate in a chemostat culture of $S$. ourctas $\operatorname{strain} 20(\mathrm{D}=0.25 \pm 0.01$ $\mathrm{h}^{-1}, 30 \mathrm{C}$.

O Bacterial dry weight; - staphylocoagulase: $\triangle$ total extracellular protein (TEP): $\Delta$ ratho staphylocoagulase/total extracellular protein: $\square$ L-lactate: acetate. 
by warying the stirrer speed. The influence of the stirrer speed on the staphylocoagulase production is shown in Fig. 2. The dissolved oxygen concentrations at 300 and $400 \mathrm{rpm}$ were $0-1 \%$ and $1-2 \%$, respectively. At higher speeds the dissolved oxygen concentrations increased to 21,45 and $82 \%$ at 500,600 and 700 rpm, respectively. At a stirrer speed of $300 \mathrm{rpm}$, staphylocoagulase, biomass and protein production were low, while L-lactate was the major fermentation product. Besides $10.5 \mathrm{~mm} \mathrm{~L}$-lactate also $6 \mathrm{~mm}$ D-lactate and $5.5 \mathrm{~mm}$ acetate was formed. At higher stirrer speeds, staphylocoagulase production increased up to an optimum at $600 \mathrm{rpm}$. At $700 \mathrm{rpm}$ staphylocoagulase and total extracellular protein production were considerably inhibited. L-Lactate production decreased with increasing stirrer speeds and acetate became the main fermentation product. The decline in acetate production at higher stirrer speeds is most probably due to a metabolic change from oxygen limitation to oxygen excess, resulting in a more complete oxidation of mannitol.

It has to be noted that anaerobic growth in this medium is not possible. Supplying the culture with nitrogen gas instead of air gave an immediate and complete inhibition of growth and staphylocoagulase production, resulting in a wash-out of the $S$. aureus culture.

At 300 and 400 rpm a complete carbon balance with respect to mannitol could be obtained : the amount of mannitol consumed was equal to the total amount of acetate, L.- and D-lactate produced. Besides acetate and lactate, acetoin was found in concentrations of $50-100 \mu \mathrm{m}$. Because these concentrations of acetoin were low and mostly only detectable during the transient state when the culture was changed from one steady-state to another, acetoin was not taken into account in the carbon balance.

Oxygen consumption measurements at $400 \mathrm{rpm}$ indicated that the $q_{\mathrm{O}_{2}}$ was 4.3 mmoles per gram dry weight and per hour. This is in agreement with a complete conversion of mannitol to acetate and carbon dioxide since this reaction would give a theoretical $9_{\mathrm{O}_{2}}$ of 4.1 mmoles per gram dry weight and per hour.

Although steady-state conditions at a stirrer speed of 600 rpm gave an optimal staphylocoagulase production, these conditions were difficult to maintain because they often gave sudden excessive foaming which inactivated staphylocoagulase and inhibited its production. The latter is caused by a dramatic decrease in aration elliciency due to impaired mixing and a wash-out of cells. Therefore. a stirrer speed of $400 \mathrm{rpm}$ was used in the other experiments.

Stimulation of staphylocoagulase production by enrichment of the air influx with carbon dioxide, as reported by Tirunarayanan (1966) was not observed. On the contrary, concentrations higher than $5 \%(\mathrm{v} / \mathrm{v})$ were found to be strongly inhibitory under our growth conditions. In this connection, it has to be noted that when the air was not enriched with carbon dioxide, the concentration of carbon dioxide in the gasphase at a dilution rate of $0.25 \mathrm{~h}^{-1}$ and a stirrer speed of $400 \mathrm{rpm}$ was already approximately $1 \%(\mathrm{v} / \mathrm{v})$.

It has been proposed by Hueting and Tempest (1977) that high concentrations 
of acetate and other low-molecular fatty acids exert a strong influence on the metabolism of microorganisms, most probably due to an uncoupling of oxidative phosphorylation. Since $S$. aureus produced acetate and lactate from mannitol, we investigated the effect of an extra addition of $20 \mathrm{~mm}$ acetate and $\mathrm{L}$ lactate to the growth medium on the production of staphylocoagulase. It was found that these acids did not inhibit staphylocoagulase production and that Llactate was mainly converted into acetate (Table 3 ).

We reported previously (Engels et all., 1978) that high concentrations of magnesium inhibited staphylocoagulase production in batch cultures. In Table 4 the influence of the magnesium concentration on staphylocoagulase and total extracellular protein production is shown. Magnesium at $400 \mu \mathrm{m}$ completely inhibited staphylocoagulase production while protein production decreased with $50 \%$. No significant effect was found on bacterial dry weight.

The influence of the casein hydrolysate concentration on staphylocoagulase production is shown in Table 5. It can be seen that staphylocoagulase production decreased only slightly with increased casein hydrolysate concentrations whereas the total extracellular protein production was inhibited considerably. An increase of the casein hydrolysate concentration from the normally used 10 $\mathrm{mg} / \mathrm{ml}$ also did increase the acetate concentration in the culture fluid. It is clear from this experiment that at casein hydrolysate concentrations of 20 and 40 $\mathrm{mg} / \mathrm{ml}$ acetate was not only formed from mannitol but also from amino acids.

Table 3. Influence of the acetate and lactate concentration on the production of staphylocoagulase and metabolism in a chemostat culture of Siaphyloc accus aureus strain $20 .\left(\mathrm{D}=0.24 \pm 0.01 \mathrm{~h}^{-1}, 400\right.$ $\mathrm{rpm}, 30 \mathrm{Cl}$.

\begin{tabular}{|c|c|c|c|c|}
\hline Addition & $\begin{array}{l}\text { Acetate } \\
(\mathrm{mm})\end{array}$ & $\begin{array}{l}\text { L-Lactate } \\
(\mathrm{mM})\end{array}$ & $\begin{array}{l}\text { Staphylo- } \\
\text { coagulase } \\
\text { (U/mg dry w) }\end{array}$ & $\begin{array}{l}\text { Bacterial } \\
\text { dry wt } \\
\text { (mg/ml) }\end{array}$ \\
\hline None & 15.6 & 0.16 & 0.56 & 2.20 \\
\hline 20 mm Acetate & 32.0 & 0.16 & 0.53 & 2.22 \\
\hline 20 mm L-Lactate & 31.7 & 0.22 & 0.54 & 2.37 \\
\hline
\end{tabular}

Table 4. Influence of the magnesium concentration on the production of staphylocoagulase in a chemostat culture of Staphylococcus aureus strain $20,\left(D=0.25 \pm 0.01 \mathrm{~h}^{-1} .400 \mathrm{rpm} .30 \mathrm{C}\right.$ ).

\begin{tabular}{|c|c|c|c|c|}
\hline $\begin{array}{l}\mathrm{Mg}^{2+} \text { medium } \\
\text { reservoir } \\
(\mu \mathrm{M})\end{array}$ & $\begin{array}{l}\mathrm{Mg}^{2+} \text { culture } \\
\text { fluid } \\
(\mu \mathrm{M})\end{array}$ & $\begin{array}{l}\text { Bact dry wit } \\
\text { (mg/ml) }\end{array}$ & $\begin{array}{l}\text { Staphylo- } \\
\text { coagulase } \\
\text { (U/ng dry wht) }\end{array}$ & $\begin{array}{l}\text { Total extra- } \\
\text { cellular protein } \\
\text { ( } \mu \mathrm{g} / \mathrm{mg} \text { dry wo })\end{array}$ \\
\hline 105 & 4 & 1.59 & 0.56 & 84 \\
\hline 236 & 76 & 1.62 & 0.18 & 60 \\
\hline 390 & 225 & 1.82 & $<0,05$ & 44 \\
\hline
\end{tabular}




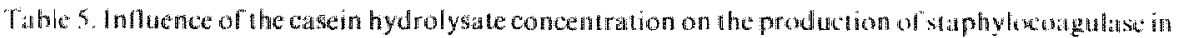

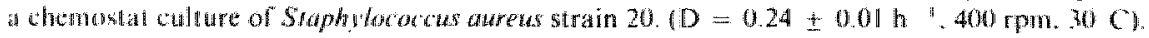

\begin{tabular}{|c|c|c|c|}
\hline & \multicolumn{3}{|c|}{ Casein bydrolysate $(\mathrm{mg} / \mathrm{ml})$} \\
\hline & 10 & 20 & 40 \\
\hline Bacterial dry weight (mg/ml) & 2.11 & 2.19 & 2.32 \\
\hline Staphylocougulase (U/mg dry wt) & 0.55 & 0.51 & 0.51 \\
\hline Total extracellular protein ( $\mu \mathrm{g} / \mathrm{mg} \mathrm{dry}$ w) & 69 & 59 & 52 \\
\hline Acetate (m) & 20.0 & 26.5 & 32.9 \\
\hline L-Lactate (mM) & 0.16 & 0.17 & 0.22 \\
\hline Mannitol (mim) & 0.27 & 0.33 & 0.77 \\
\hline Osmolarity (mOsm) & 185 & 324 & 565 \\
\hline
\end{tabular}

Analysis of the amino acid composition of the culture fluids (data not shown) revealed that, when the casein hydrolysate concentration was $10 \mathrm{mg} / \mathrm{ml}$, most amino acids were present in excess of growth requirement, except aspartate, threonine, serine, glutamate, glycine and alanine, which were almost completely consumed. When the casein hydrolysate concentration was raised to $20 \mathrm{mg} / \mathrm{ml}$. only threonine and serine could not be detected in the culture fluid. At a concentration of $40 \mathrm{mg} / \mathrm{ml}$ casein hydrolysate, all amino acids were detectable in the extracellular fluid in concentrations greater than $1 \mathrm{~mm}$. Cysteine and tryptophan were not present in the medium and tyrosine only in trace amounts. Addition of these amino acids did not affect staphylocoagulase or biomass production. An increase of the casein hydrolysate concentration allso implicated an increase of the osmolarity of the medium due to the high $\mathrm{NaCl}$ content $\left(14^{\circ}\right.$ $w / w)$ of casein hydrolysate. In Table 5. however, it can be seen that the slight changes in the production of staphylocoagulase and biomass did not correlate with the large changes in this parameter.

The influence of temperature on staphylocoagulase and protein production is shown in Fig. 3. Staphylocoagulase production was optimal at a temperature of $3031 \mathrm{C}$, while protein production increased with increasing temperatures. The biomass production is not influenced in this temperature range. It is of interest to note that the optimal temperature for staphylocoagulase production differed from the generally used cultivation temperature of $37 \mathrm{C}$.

Production of staphylocoagulase and other extracellular enzymes by strain 15

To determine whether the kinetics of staphylocoagulase production was similar to that of the production of other extracellular enzymes. the excretion of penicillinase, DNase and phosphatase was also followed. However, the production of these enzymes by strain 20 as well as strain 104 was low in the casein hydrolysate medium and could not be determined reliably. Therefore, the influence of growth rate on the production of staphylocoagulase, penicillinase, 


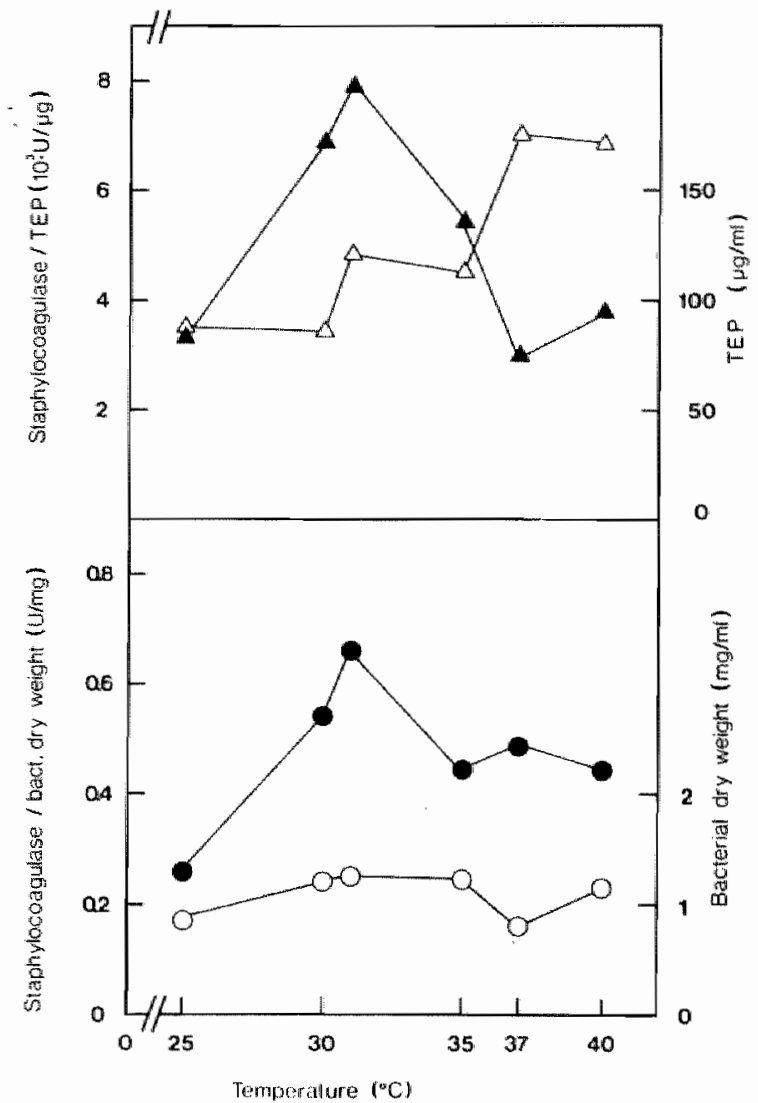

Fig 3. Inthene of tempenature on the production of staphylocongulase. lotal cxiracellutar protein

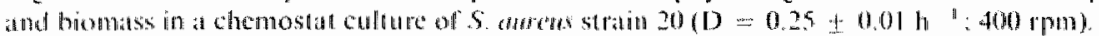

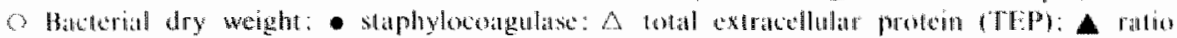

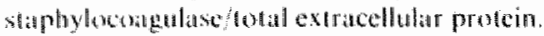

DNase and phosphatase was studied in strain 15, which produced the latter three enzymes in considerably higher amounts than the previously mentioned strains. In Table 6 it can be seen that the specific rate of production of extracellular enzymes was growth-rate dependent. The production pattern of staphylocoagulase and penicillinase had an optimum at a $\mathrm{D}=0.22 \mathrm{~h}^{-1}\left(\mu_{\max }=0.8-1.0\right.$ $\left(h^{-1}\right)$; the production of DNase, phosphatase and total extracellular protein increased with increasing growth rates. The decrease in bacterial dry weight with increasing growth rates and a dissolved oxygen concentration lower than $I^{\text {" }}$ correlates again with oxygen-limiting conditions. Also in this strain the specilic rate of staphylocoagulase production in chemostat culture was approximately six times higher than that in batch culture (data nol shown). 
Table 6 . Influence of dilution rate on some cullure parameters and the production rate of extracelWular enymmes in a chemostat culture of Shaphytococcus aurets.s strain $15 .(400 \mathrm{rpm}, 30 \mathrm{C}$ ).

\begin{tabular}{|c|c|c|c|c|}
\hline & \multicolumn{4}{|c|}{ Dillution rate $\left(\mathrm{h}^{-1}\right)$} \\
\hline & 0.11 & 0.16 & 0.22 & 0.35 \\
\hline Bicterial dry weight $(\mathrm{mg} / \mathrm{mll})$ & 1.45 & 1.35 & 1.28 & 0.94 \\
\hline Mannitiol in cullure fluid (mM) & 0.11 & 0.22 & 0.66 & 7.2 \\
\hline Total protein ( $\mu \mathrm{g} / \mathrm{mg}$ dry w/ $\mathrm{h})$ & 18.4 & 19.2 & 24.9 & 36.9 \\
\hline Staphylocoagulase (U/mg dry wt $\cdot h$ ) & 0.10 & 0.20 & 0.23 & 0.17 \\
\hline Penicillinase (mPerret U/mg dry wt h) & 0.13 & 0.27 & 0.55 & 0.19 \\
\hline DNalse (U/mg dry wt $\cdot \mathrm{h})$ & 0.05 & 0.10 & 0.24 & 0.38 \\
\hline Neural phosphatase (m U/mg dry wh th) & 0.06 & 0.19 & 0.43 & 1.94 \\
\hline
\end{tabular}

\section{Staphylocoagulase production by strain 104}

Because our study of staphylocoagulase production had been started in batch cultures of strain 104 (Engels et al., 1978) it was of interest to study the influence of the dilution rate on the staphylocoagulase production rate in a chemostat culture of strain 104.

The specific rate of staphylocoagulase production as depicted in Fig. 4, in-

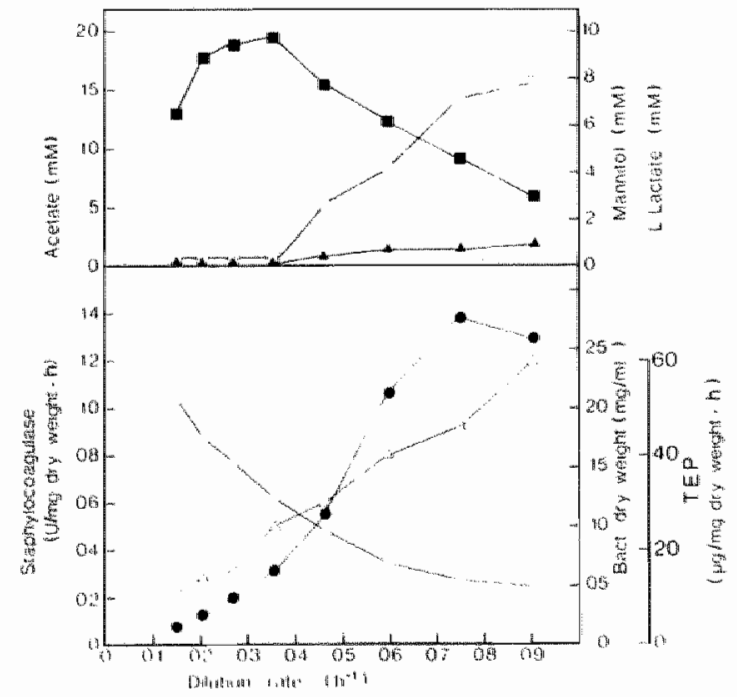

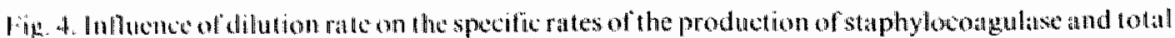

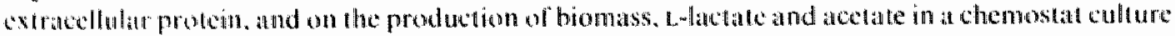

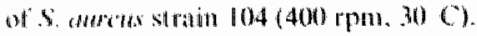

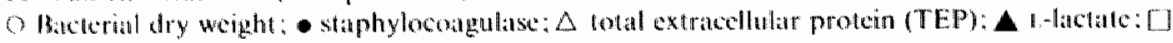
mimilol: wisctalc. 
creased to an optimum at $\mathrm{D}=0.76 \mathrm{~h}^{-1}$. In contrast to the other strains used in this study, strain 104 produced less staphylocoagulase in chemostal culture than in batch culture $(0.67 \mathrm{U} / \mathrm{mg}$ ws. $1.5-2.0 \mathrm{U} / \mathrm{mg})$. At even higher dilution rates the production rate declined due to wash-out conditions $\left(\mu_{\max }=0.9-1.1 \mathrm{~h}^{-1}\right)$. The total extracellular protein production increased with increasing dilution rates. Bacterial dry weight decreased with increasing dilution rates indicating oxygenlimiting conditions.

Dissolved oxygen concentration measurements revealled values lower than $1 \%$ up to a $\mathrm{D}=0.36 \mathrm{~h}^{-1}$. At higher dillution rates the dissolved oxygen concentration progressively increased to $41 \% \mathrm{at}, \mathrm{D}=0.76 \mathrm{~h}^{-1}$.

At dilution rates in the range of $0.20-0.36 \mathrm{~h}^{-1}$ mannitol was mainly converted to acetate; at higher dilution rates also a minor amount of L-lactate was formed, while acetate production declined, a phenomenon similar to that observed in strain 20. No explanation can be given for the production of L-lactate under these conditions. Addition of $20 \mathrm{~mm}$ acetate at a $\mathrm{D}=0.76 \mathrm{~h}^{-1}$ did not influence the specific rate of staphylocoagulase production.

Under conditions of optimal production of staphylocoagulase, staphylocoagulase-negative mutants of strain 104 invariably appeared after a number of generations and these mutants took over the staphylocoagulase-producing population for more than $90^{\circ} \%$. The same phenomenon was observed with strain NCTC 8178 (unpublished results). Because the precise moment of this take-over was mostly unpredictable, no further experiments were done with strain. 104. In a separate study the selective advantages of the staphylocoagulasenegative mutants of S. aureus 104 and NCTC 8178 will be investigated.

\section{Discussion}

In general, the production of extracellular enzymes follows one of four patterns and it is assumed that the relationship between enzyme production and growth rate depends on the chatracteristics of the regulating mechanisms involved (Bull, 1972; Dean, 1972; Glenn, 1976). The four patterns of enzyme production, as reviewed by Wiersma and Harder (1978), includes constitutive enzymes, constitutive enzymes controlled by catabolite repression, inducible enzymes, and inducible enzymes controlled by calabolite repression. On the basis of this classification, one may conclude that the staphylocoagulase and penicillinase production (Fig. 1. Table 6) by the two bovine strains 20 and 15 is controlled by induction and catabolite repression. The production pattern of staphylocoagulase by strain 104 differed from that of the bovine strains, and is like that of a constitutive enzyme, although the production of the enzyme is relatively low at lower dilution rates and disproportionally high at high dilution rates. The absence of a mode of regulation in strain 104 similar to that in strains 20 and 15 , may be due to the fact that the first strain has been subcultured for 
more than 30 years in witro, so that regulation has been lost. whereas the bovine strains were isolated only recently. The profile of the production patterns of DNase and phosphatase by strain 15 parallels the total extracellular protein production pattern of strain 20,15 and 104 and is. as expected. like that of constitutive enzymes. From these data it can be concluded that in strains 20 and 15 the production of staphylocoagulase and DNase, both regarded as the two main criteria for separating $S$. aureus from other staphylococci (Baird-Parker, 1974), are independently regulated.

Catabolite repression of staphylocoagulase production in strain 20 by mannitol could not be demonstrated. This finding is in agreement with those of Arvidson et al. (1976) who found with $S$. atreas strain V8 that the synthesis of phosphatase, protease $\mathbb{I}$ and staphylokinase were not under severe catabolite repression. Holme and Arvidson (1976) found increasing levels of phosphatase and staphylokinase with increasing growth rates while protease I was produced with an optimum at a $\mathrm{D}=0.4 \mathrm{~h}^{-1}$. Jarviset al. (1975) studied the production of extracellular enzymes in continuous cultures of $S$. atwets strain $S 6$ under magnesium- and oxygen-limited growth conditions. They reported that enterotoxin B, lipase. DNase and total extracellular protein increased with increasing dilution rates, whereas lysozyme and $\beta$-haemolysin production decreased with increasing growth rates. Moreover, it was found that, with exception of DNase, the production of these enzymes was strongly inhibited by $100 \mathrm{~mm}$ glucose.

Besides the growth rate, the following parameters are also important: the concentration of oxygen and of magnesium and the energy state of the cells. It has been reported that a great number of extracellular enzymes is produced optimally by $S$. aureus strains under oxygen-limited growth conditions (Arvidson et al., 1976; Carpenter and Silverman, 1974; Jarvis et al., 1973). From our studies it is clear that staphylocoagulase is produced under similar conditions by all $S$, awros strains studied. Acetate and carbon dioxide were the predominant end products of the oxidation of mamnitol. while high lactate production was only found at very low concentration of oxygen (Fig. 2). Gardner and Lascelles (1962) and Strusters and Winkler (1963) reported acetate and carbon dioxide as main products of glucose metabolism, while $510^{\circ}$ " of the glucose carbon appeared as lactate under aerobic culture conditions. Garrard and Lascelles (1968) demonstrated that lactate dehydrogenase levels and, therefore. lactate production are considerably entanced under aerobic conditions in the absence of a functional respiratory chain and under aerobic conditions when pyruvate was the sole fermentable carbon source. Thus, in our experiments low oxygen levels could stimulate lactate dehydrogenase activity which resulted in high concentrations of lactate.

Since mannitol was mainly converted to acetate and lactate, and not to cell mass, it is likely that it functioned as an energy source rather than as a carbon source. In the absence of mannitol, the staphylocoagulase production was con- 
siderably decreased and this suggests that the energy state of the cell is of great importance in the regulation of staphylocoagulase production. Because increased concentrations of mannitol, acetate or lactate did not inhibit staphylocoagulase production, it was very difficult to indicate which of the other medium constituents could function as a repressor or inducer. Since amino acids could function as energy-, carbon- as well as nitrogen-source. the possibility existed that these components or their metabolites played a role in the regulation of staphylocoagulase production. Although a number of a mino acids were depleted during optimal staphylocoatgulase production by strain 20. an increase of the casein hydrolysate concentration to $40 \mathrm{mg} / \mathrm{ml}$ (so that all amino acids were present in excess of growth requirement) did not lead to an increase of staphylocoagulase production (Table 5). Therefore, it will be difficult to elueidate the exact mechanism of staphylocoagulase production. considering the complex nutrient requirements of $S$ atreus because of which the use of almost complete amino acid mixtures will be inevitable for optimal exoenzyme production (see also Björklind and Arvidson, 1978).

It has been commonly observed that under magnesium limitation, the steadystate bacterial culture density decreased with increasing dilution rates, because the intracellular magnesium requirement varies substantially with the growth rate, being greatest at the maximal growth-rate value (Tempest, 1969). It was, therefore, possible that the decline of the bacterial dry weight curves at increased growth rates was not only due to the limited availability of oxygen alone but also to the magnesium limitation. However, an increase in magnesium concentration did not enhance the bacterial dry weight significantly (Table 4); on the other hand an increase of the stirrer speed from $400 \mathrm{rpm}$ to higher values did not enhance the bacterial dry weight substantially either (Fig. 2). Hence, it seems probable that both nutrients must be available at growth-limiting concentrations.

The nature of the inhibition of staphylocoagulase production by higher concentrations of magnesium as shown in Table 4 is unclear. As lar as we are awatre there has been only one other report describing the necessity of low magnesium concentrations for the optimal secretion of an enzymc. Bovallius $(1969)$ demonstrated that a magnesium limitation had an adverse effect on biomass production but greatly stimulated the synthesis of a cholinesterase solubilizing factor by a Cylophaga $\mathrm{sp}$. Moreover, he showed that cell lysis was not a factor in the release of this enzyme. Although the bulk of the intracellular magnesium is associated with the ribosomes. a small portion is associated with some components of the cell wall and membranes (Meers and Tempest, 1970). Thus, it is possible that magnesium is involved intimately in the permeability of bacterial membranes towards various intra- and extra-cellular substances. A further study is necessary to investigate the precise mode of action of magnesium.

In summary, we conclude that $S$. aureus produces staphylocoagulase under magnesium- and oxygen-limited growth conditions. Optimal production takes 
place at submaximall growth rates, limited oxygen availability and all a temperalure of $30-31 \mathrm{C}$. Two strains of $S$ aureus (15 and 20) produced substantially more staphylocoagulase in chemostat culture as compared with batch cultures of the same organisms. This indicates that chemostat culture, by virtue of its ability to provide constant and specific environmental conditions, may prove to be a better culture technique for the production of this extracellular enzyme. Moreover, it was demonstrated that the production of optimal amounts of staphylocoagulase was not always related to a maximal production of biomass and total extracellular protein.

We wish to thank Dr O. M. Neijssel for helpful discussions and for critically reading the manuscript. We are grateful to Dr J. M. F. Saes for supplying the bovine S. aureus strains.

Received 13 August 1980

\section{REFERENCES}

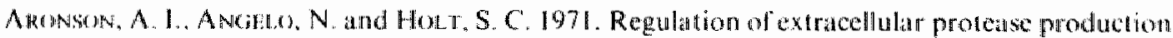

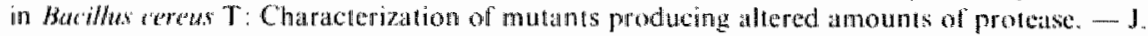
Bacteriol. 106: 1016 1025.

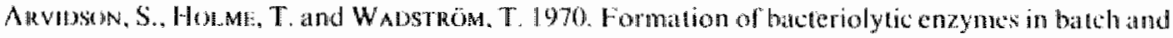

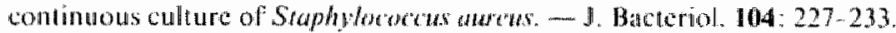

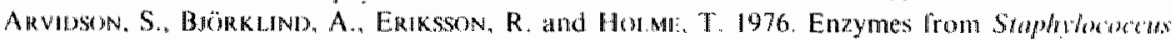
anerus. p. 238-250. in A. C. R. Dean, D.C. Ellwood, C. G. T. Evans and I. Melling, (eds). Continuous culiure: application and new fields. Vol. 6- Ellis Horwow. Chichester.

BAIRD-PARKi:R, A. C. 1974. Genus 11 Shaphylococcus p. 483489 . In R. E. Buchan and N. E. Gibbons, (eds), Bergey"s manual of determinative bacteriology. 8th ed. - The Williams and Wilkits Company, Baltimore.

Bergmeyer, H.U. und Bernt, E. 1974. Lactat-Dehydrogenase. U.V. Test mä Pyruvat und NADH. p. 607-612. In H.-U. Bergmeyer. (ed.), Methoden der enzymatischen Analyse. Vol. 1.3rd ed. Verlag Chemie, Woinheim.

BbokKHIND. A. and ARWDSON. S. 1978 . Influence of amino acids on the synthesis of an extracellulat proteindse from Staphlococcus amews.-J, Gen. Microbiol. 107:367-375.

Bovatluss, A. 1969 . Production of a cholinesterase-solubilizing factor from a Clifophaga sp. by continuous cultivation. - Can. J. Microbiol 15:429-433.

Buti. A. T. 1972. Envirommental factors imfuencing the symthesis and excretion of extracellular macromolecules. - J. Appl. Biotechnol. 22:261-292.

CARPENTIR, D, F. and SILERMAN, G, 1. 1974. Staphylococoal enterotoxin B and nuclease prodtiction under controlled dissolwed oxygen conditions. - Appl. Microbiol. 28:628-637.

Dswrs. E. A. MCGul. D. J. and Midex. M. 1971. Antysis of fermentation producte.- Methods in Microbiology 6A:53-215

Di: A. A.C.R. 1972. Inthence of environment on the control of enzyme synthesis. -. J. Appl. Chem. Biotechmol. 22: 245-259.

EvGlis, W. KAMUS, M. A. F. and VAN BOVEN, C.P. A. 1978, Influence of cultivation conditions on

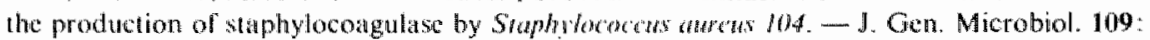
237243

Fivans, C. G. T. HFRBert, D. and Trmpist, D. W. 1970. The continuons cultivation of microosganisms. II Construction of a chemostat.- Methods in Microbiology 2: 277-328. 
GARDNER, J,F. and LASCQLES. . 1962. The requirement for acetate of a streptomycin-resistan strain of Sraphylococows aureus. - J, Gen. Microbiol. 29: 157-164.

GARRARD, W. and LASCELLE, J. 1968. Regulation of Staphylocorcus awhe hactate dehydrogenase. - J. Bacteriol 95: 152-156.

GAWEHN, K. And BERGMEYer, H.-U. 1974. D-Lactat, p. 1538-1541, In H.-U. Bergneyer. (ed.), Methoden der enzymatischen Analyse. Vol. 2. 3rd ed. - Verlag Chemie. Weinheim.

GLenN, A. R. 1976. Production of extracellular proteins by bacteria. p. 41 -62. Mn M. P. Starr, 1. L Ingrabam and S. Rallel. (eds). Annual Reviews of Microbiology. Vol. 30. - Anmual Reviews Inc. Palo Alto.

Gosm, B. K., Wouters, J. T. M. and LAMPEN, J. O. 1971. Disuribution of the sites of allatine phosphatase(s) activity in vegetative cells of Baciltus subrilus - J. Bacteriol. 108:928-937.

GUTMANN, 1. und WAHLEFLD, A. W. 1974. L-Lactat, Bestimmung mil Lactat-Dehydrogenase und NAD. p. 1510-1514. In H.-U. Bergmeyer, (ed.), Methoden der enzymatischen Analyse. Vol. 2, 3 nd ed. - Verlag Chemie, Weinheim.

Heins, J. N., TANUCH, H. and Anfrnsen, C. B. 1966. Extracellular nuclease from Sinphwococon atures. p. 79-82. In J. Cantoni and D. Davies, (eds). Procedures in nucleic acid research.- Harper and Row. New York.

Herbert, D.. Phipes, P. J, and Strange, R. E, 1971 . Chemical analysis of mictrobial cells. Methods in Microbiology 5B: $209-344$.

HoLME, T. and WADströM, T. 1971. A continuous process for the production of extracellubur proteins by Staphylococus arreus. - Acta Pathol. Microbiol. Scand. Sect. B 79:414.420.

Holme, $T$, and ARwidson, $S$. 1976 . Changes in $Y_{0,}$ in relation to growh rate and production of

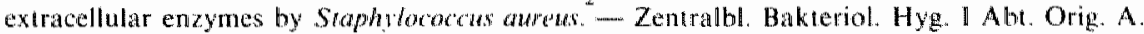
Supplement $5: 181-188$

HOLz, G. und BERGMEYER, H.-U. 1974. Acetat, Bestimmung mit Acetat-kinase und Hydroxylamin. p. 1574-1578. In H.-U. Bergmeyer, (ed.), Methoden der enzymatischen Anzlyse. Vol, 2, 3rd ed... Verlag Chemie, Weinheim.

Hunting. S. and Tempest, D. W. 1977. Inpuence of acetale on the growth of Cardida whis in contintious culture. - Arch Microbiol. 115: 73-78.

JARvis. A. W.. LAWRENCE, R. C, and PRTTCHARD, G. G. 1973. Production of staphylococcal anteroloxins A, B and $C$ under conditions of controlled $p H$ and aeration. - Infect Imman. 7 : 847.854

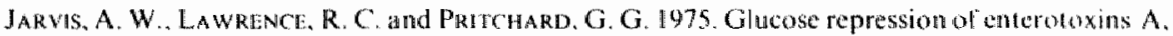
$B$ and $C$ and other extracellular proteins in staphylococci in batch and continuous culture. $-J$. Gen. Microbiol. 86:75 87

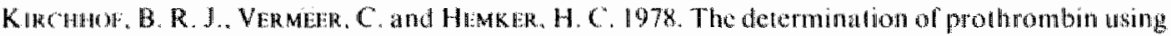
synthetic chromogenic substrates: Choice of a suitable activalor. - Thrombos. Ress. 2: 219 232.

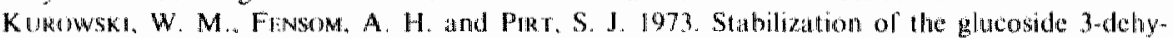
drogenase in Agrobactoritw fanchacions. I. Eftect of growlh conditions on the enzyme activity and its decay. - J. Gen. Microbiol. 73: XV.

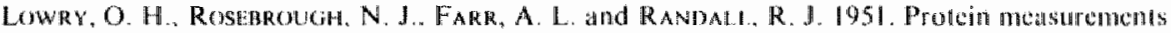
with the Folim phenoll reagent. - J. Biol. Chem. $193: 265.275$

MLERS. J. L. and TEMPEST. D. W. 1970 . The influence of growth limiting substrate and medium NaCl concentration on the synthesis of magnesium-binding sites in the walls of Buthlow subihus war. niger. - I. Gen. Microbiol. 63:325-333

Mryer, W. 1967. A proposal for subdividing the species Staphlocer as ameas. - Int. I. Syst. Bacteriol. $17: 387394$.

Nassel. O. M. and TEmpest, D. W. 1979. The physiology of metabolite over-production, p. 53.82. In A. T. Bull, D. C. Ellwood and C. Ratledge, (eds). Microbial technology, Society for Generil Microbiology Symposium 29. - Cambridge University Press, Cambridge.

SARCENT, M. G. 1968. Rapid fixed-time assay for penicillinase. - J. Bacteriol. 95: 1493-1494. 


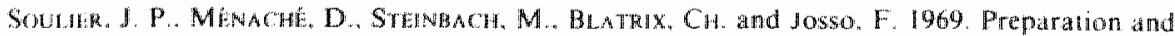
climical use of P.P.S.B. (factors II, VII, X and IX concentrate). - Thrombos. Diath Haemor. Suppl. $35: 61 \cdots 9$

SHUGAR, D. 1952. The medsurement of lysozyme activity and the ultra-violet inactivation of lysozyme, - Biochim. Biophys. Acta 8: 302-309.

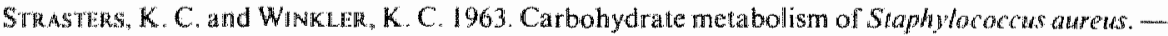
J. Cen. Microbiol. $33: 213-229$.

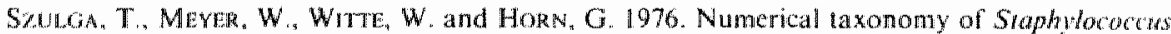
aurcens, p. 102 104. In J. Jeljaszewicz, (ed ), Staphylococci and staphylococcal diseases. - Gustav Fischer Verlag, Stuntgart.

TrmpEst, D. W. 1969. Quantitative ralationships between inorganc cations and anionic polymers in growing bacteria. p. $87-111 . \mathrm{ln}$ P. Meadow and S. J. Pirt, (eds). Microbial growth. Society for Genomal Microbiology Symposium 19. - Cambridge University Press. Cumbridge.

THRunakaranaw, M. O. 1966. Investigations on the enzymes and toxins of staphylococci. - Acta Pathol. Microbiol. Scand. Sect. B 68 273-280.

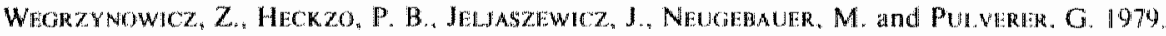
Pseudocoaguatase activity of Staphylococei.-J. Clin. Microbiol 9: $15-19$

W/stekfelo, W. W. 1945. A colorimetric determination of blood acetoin. - J. Biol. Chem. I6.1 $495-502$.

WIERSMA, M. and HARDER, W. 1978. A continuous culture sludy of the regulation of extracelluar protease production in Vibrio $S A L$. Antonie van Leuwenhoek $44: 14 \rrbracket-155$. 
SECRETION OF STAPHYLOCOAGULASE BY STAPHYLOCOCCUS AUREUS: THE ROLE OF A CELL-BOUND INTERMEDIATE

SUMMARY

A cell-bound staphylocoagulase could be detected in chemostat cultures of Staphylococcus aureus 104 under magnesium- and oxygen-limited growth conditions. A distribution study revealed that $81 \%$ of the enzyme was membrane-bound and could be optimally released by Triton $x-100$. The remaining part was located in the periplasmic space and was released during protoplasting of the organism. From inhibition studies with cerulenin, quinacrine, lincomycin and chloramphenical, it was concluded that the cell-bound form was a precursor in the secretion of extracellular staphylocoagulase. The involvement of a lipid intermediate/exoprotein-releasing protease system in the secretion of staphylocoagulase, and of exoproteins in general, is discussed.

\section{INTRDDUCTIDN}

The secretion of bacterial exoproteins has been extensively investigated by Lampen and co-workers in the case of penicillinase production by Bacillus licheniformis $749 / \mathrm{C}$. From these studies, a working hypothesis for the export of penicillinase has been proposed (Lampen, 1978). The model postulates the existence of a membrane-bound form of the enzyme which differs structurally from the exopenicillinase in that it has an additional sequence of 24 amino acid residues and $a$ phosphatidylserine residue at the $\mathrm{NH}_{2}$-terminus (Yamamoto and Lampen, 1976 a, b, c). This strongly hydrophobic tail is considered to anchor the hydrophylic exoenzyme firmly in the membrane. A specific serine protease, located at the outer surface of the cytoplasmic membrane cleaves the covalent bond between the enzyme and the phospholipopeptide moiety, thus allowing the release of the exoenzyme (Aiyappa, Traficante and Lampen, 1977). Consistent with this hypothesis is the finding that 
cerulenin, an inhibitor of lipid synthesis (Omura, 1976) and quinacrine, an inhibitor of the penicillinasereleasing protease (Traficante and Lampen, 1977) have a marked effect on penicillinase production by $B$. Iicheniformis when added at concentrations which only slightly affect growth (Fishman, Rattem and Citri, 1978; Lampen, 1978). Similar results have been obtained for other extracellular proteins, such as enterotoxin A (Berkeley et al., 197B) and enterotoxins B and C (Altenbern, 1977) of Staphylococcus aureus, levansucrase of Bacillus subtilis (Caulfield et al., 1979) and aminopeptidase of Escherichia coli (Lazdunski, Murgier and Lazdunski, 1979), suggesting a mechanism which is widespread.

Although the production of staphylocoagulase by S. aureus has been subject of many investigations (Altenbern, 1966; Duthie and Haughton, 1958; Engels, Kamps and Van Boven, 197B and 1980; Fahlberg and Marston, 1960), the cellular precursor of staphylocoagulase is unknown and the biosynthetic pathway leading to its formation has not been established. Altenbern (1966) and Engels et al. (1978) were unable to detect staphylocoagulase in cell lysates, prepared by lysostaphin treatment of $\mathrm{S}$. aureus. However, fluoresceinlabeled antibodies to purified staphylocoagulase attach to the surface of cells of staphylocoagulase-positive staphylococci, demonstrating that this enzyme is present at the cell surface (Blobel and Berman, 1960). Therefore, a study was undertaken to investigate the presumptive presence of a cell-bound staphylocoagulase. In order to elucidate the possible mechanism involved in the secretion of staphylocoagulase, the influence of cerulenin, quinacrine and the protein synthesis inhibitors lincomycin and chloramphenicol on the production of staphylocoagulase in magnesium- and oxygen-limited cultures of $\underline{5 \text {. aureus }} \mathbf{1 0 4}$ was studied.

MATERIALS AND METHODS

Drganism

Staphylococcus aureus 104 (after Tager) kindly provided by Dr. J.P. Soulier (Centre National de Transfusion Sanguine, Paris) was maintained by monthly subculture on nutrient agar slants.

Growth conditions

Continuous cultures of $\mathrm{S}$. aureus 104 were maintained in casein hydrolysate medium (containing $100 \mu \mathrm{M} \mathrm{MgCl} l_{2}$ ) 
in Bioflo $C 30$ chemostats (New Brunswick Scientific Co. Inc., New Brunswick, N.J., U.S.A.) as described by Engels et al. (1980). The dilution rate was $0.28 \pm 0.01$ $\mathrm{h}^{-1}$ unless otherwise stated. The $\mathrm{pH}$ was maintained at a value of 7.4 by means of an automatic titrator with $2 \mathrm{M}$ $\mathrm{KOH}$ as the titrant. The temperature was held at $30^{\circ} \mathrm{C}$, the stirrer speed was $400 \mathrm{rpm}$ and the culture volume 320 $\mathrm{ml}$. Silicone antifoaming agent (purchased from BDH) was added automatically as a $2 \%(w / v)$ solution at regular time intervals.

\section{Analytical procedures}

Bacterial dry weight was measured by the procedure of Herbert, Phipps and Strange (1971). Total extracellular protein was determined, after overnight dialysis of culture supernatants against double glass distilled water at $0-4^{\circ} \mathrm{C}$, according to Lowry et al. (1951).

Extracellular staphylocoagulase activity was determined spectrophotometrically with human prothrombin and Chromozym TH (Boehringer Mannheim, W. Germany) as described previously (Engels et al., 1980).

Cell-bound staphylocoagulase activity was determined as follows: $1 \mathrm{ml}$ of culture fluid was centrifuged $(5 \mathrm{~min}$ at $8000 \mathrm{~g})$ and the cells were washed three times with phosphate buffered saline, $\mathrm{pH} 7.4$ (PBS), containing 50 $\mu \mathrm{g} / \mathrm{ml}$ chloramphenicol. After the final washing the cells were taken up in $1 \mathrm{ml}$ of PBS and $100 \mu 1$ of this cell suspension was added to $500 \mu \mathrm{l}$ of the assay mixture used for the extracellular staphylocoagulase assay. Subsequently, the staphylocoagulase activity was measured as described above.

Proteolytic activity was determined with azocasein (Sigma) according to Hazen et al. (1965).

\section{Purification of staphylocoaqulase}

Staphylocoagulase was produced as described by Engels et al. (1978) and purified by chromatography on a bovine prothrombin-Sepharose $4 \mathrm{~B}$ column according to Igarashi, Morita and Iwanaga (1979).

The purified staphylocoagulase had a specific activity of $2000 \mathrm{U} / \mathrm{mg}$ protein.

Preparation of goat anti-staphylocoagulase

Purified staphylocoagulase was precipitated with aluminium hydroxide and resuspended in PBS to a final concentration of $1 \mathrm{mg} / \mathrm{ml}$ according to Hudson and Hay (1976). The first intramuscular injection was given with $1 \mathrm{ml}$ precipitated staphylocoagulase mixed with $1 \mathrm{ml}$ 
Freund complete adjuvant. A second and third injection (1 $\mathrm{mg}$ alluminium hydroxide precipitated staphylocaagulase without Freund adjuvant) was given after intervals of 3 weeks. Seven days after the third injection, blood was collected in $0.1 \mathrm{M}$ sodium oxalate, $\mathrm{pH} 7.0$ and centrifuged at $1200 \mathrm{~g}$ for $15 \mathrm{~min}$. To remove procoagulant activity and complement, the supernatant was adsorbed three times with barium sulphate $(100 \mathrm{mg} / \mathrm{ml})$ for $30 \mathrm{~min}$ at $4^{\circ} \mathrm{C}$ and heat inactivated at $56^{\circ} \mathrm{C}$ for $30 \mathrm{~min}$. The adsorbed and inactivated antisera were centrifuged for $30 \mathrm{~min}$ at $12000 \mathrm{~g}$ at $4^{\circ} \mathrm{C}$.

Staphylocoagulase release from washed cells

Cells were harvested from the chemostat, washed three times with PBS containing $50 \mu \mathrm{g} / \mathrm{ml}$ chloramphenicol and resuspended in this buffer plus the releasing agent to be tested. After incubation at $20^{\circ} \mathrm{C}$ for $30 \mathrm{~min}$ with gentle shaking, the cells were centrifuged for $15 \mathrm{~min}$ at $15000 \mathrm{q}$ and resuspended in PBS containing $50 \mu \mathrm{g} / \mathrm{ml}$ chloramphenicol. Staphylocoagulase in the supernatants and in the resuspended cells were determined as described above.

\section{Preparation of protoplasts}

Cells were harvested from the chemostat, washed three times with PBS containing $50 \mu \mathrm{g} / \mathrm{ml}$ chloramphenicol and suspended in the protoplasting medium containing $4 \mathrm{M}$ $\mathrm{NaCl}, 50 \mathrm{mM}$ phosphate buffer $\mathrm{pH} 7.4,10 \mathrm{mM} \mathrm{MgCl} 2,50$ $\mu \mathrm{g} / \mathrm{ml}$ Iysostaphin (Schwarzmann, W. Germany) and $50 \mu \mathrm{g} / \mathrm{ml}$ chloramphenicol. The suspension was incubated with gentle shaking at $20^{\circ} \mathrm{C}$ for $60 \mathrm{~min}$. The crude protoplasts were subsequently washed with protoplasting medium onitting lysostaphin.

Preparation of membranes

Membranes were prepared according to the following two methods:

i) Washed protoplasts were suspended in PBS, $10 \mathrm{mM}$ $\mathrm{MgCl}_{2}, 50 \mu \mathrm{g} / \mathrm{ml}$ chloramphenicol, $20 \mu \mathrm{g} / \mathrm{ml}$ deoxyribonuclease and incubated at $20^{\circ} \mathrm{C}$ for $60 \mathrm{~min}$.

ii) Washed cells were suspended in a mixture containing PBS, $10 \mathrm{mM} \mathrm{MgCl} 2,50 \mu \mathrm{g} / \mathrm{ml}$ lysostaphin, $20 \mu \mathrm{g} / \mathrm{ml}$ deoxyribonuclease (Merck, Darmstadt, W. Germany) and $50 \mu \mathrm{g} / \mathrm{ml}$ chloramphenicol and incubated at $20^{\circ} \mathrm{C}$ for $60 \mathrm{~min}$. The crude membrane fractions were subsequently isolated by centrifugation for $60 \mathrm{~min}$ at $48000 \mathrm{~g}$ and washing with PBS. 
Solubilization of membrane-bound staphylocoaqulase

Membranes were suspended in PBS containing $0.1 \%(w / v)$ sodium deoxycholate or $1 \%(v / v)$ Triton $X-100$. The suspension was centrifuged for $30 \mathrm{~min}$ at $48000 \mathrm{~g}$ and the solubilized staphylocoagulase was measured.

Inhibitors

The inhibitors were dissolved in PBS and sterilized by membrane filtration before use. Addition to the chemostat occurred as a single dose to the indicated final concentrations. Quinacrine dihydrochloride and cerulenin were obtained from Sigma Chemical Company (St. Louis, U.S.A.). Chloramphenicol was purchased from Serva (Heidelberg, W. Germany). Lincomycin hydrochloride was a product of Upjohn Company (Kalamazoo, U.S.A.).

\section{RESULTS}

Secretion of staphylocoagulase during growth of 5 . aureus 104 in chemostat culture

It has been shown previously (Engels et al., 1980) that in chemostat cultures of $\underline{S}$. aureus staphylocoagulase was formed optimally under oxygen- and magnesiumlimited growth conditions. We have now examined the secretion of this enzyme in these cultures and the possible presence of a cell-bound form. In Table 1 it can be seen that besides an extracellular staphylocoagulase also a cell-bound staphylocoagulase was present. When in the assay of cell-bound staphylocoagulase prothrombin was omitted, hydrolysis of the chromogenic substrate could not be detected indicating that the cell-bound activity was due specifically to staphylocoagulase. Incubation of the cells for $30 \mathrm{~min}$ at $37^{\circ} \mathrm{C}$ with antiserum to purified extracellular staphylocoagulase completely abolished the cell-bound staphylocoagulase activity whereas preimmune serum did not inhibit at all. It could be calculated that approximately $1.3 \%$ of the total extracellular protein was staphylocoagulase and that the amount of cell-bound staphylocoagulase was about 0.3 $\mu \mathrm{g} / \mathrm{mg}$ dry weight of cells.

${ }_{-1}$ An increase of the dilution rate from 0.28 to 0.55 $\mathrm{h}^{-1}$ resulted in a simultaneous increase of the production rates of extracellular and cell-bound staphylocoagulase, so that the ratio extracellular/cell-bound staphylocoagulase remained constant (data not shown).

Addition of $2 \% \mathrm{NaCl}$ to the growth medium had a remarkable effect on the amount of cell-bound staphylo- 


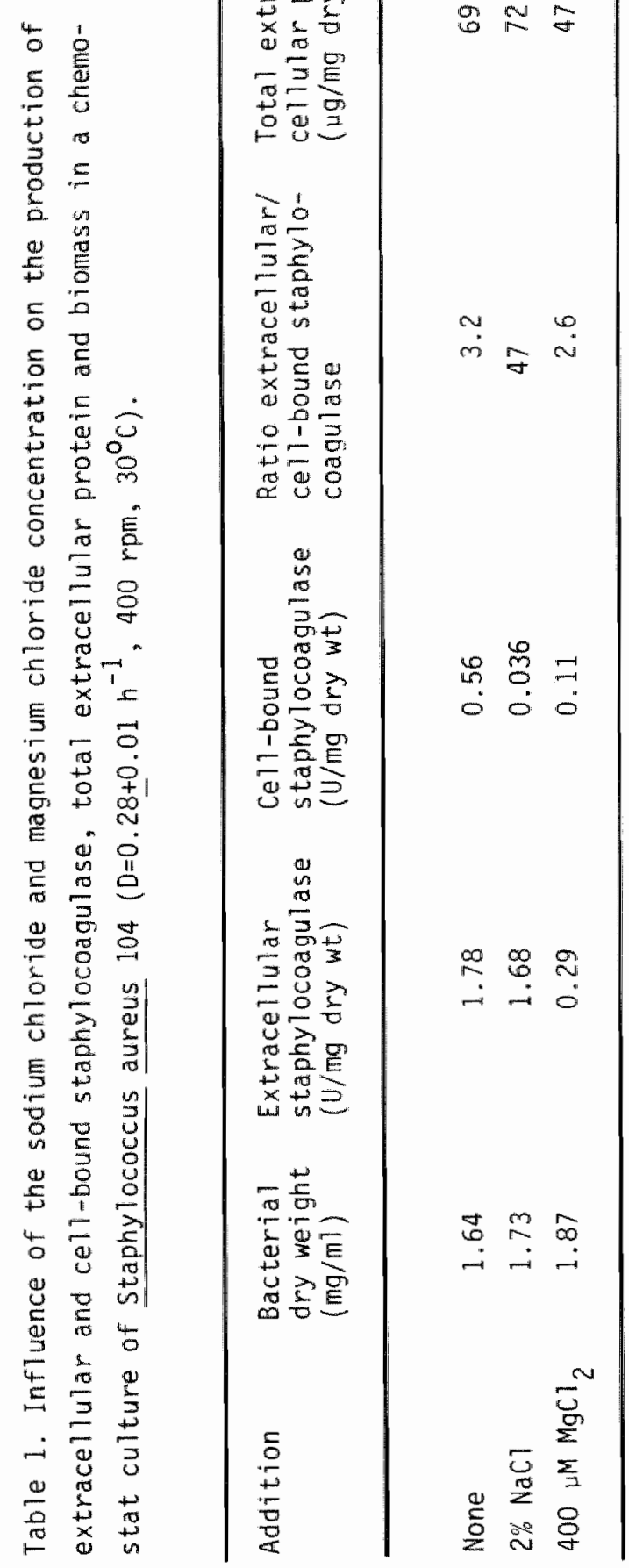


coagulase whereas the steady-state concentratian of extracellular staphylocoagulas was not affected (Table 1).

Since the production of extracellular staphylocoagulase is inhibited strongly by high concentrations of magnesium (Engels et al., 1980) we investigated the influence of an addition of $400 \mu \mathrm{M}$ magnesium chloride to the growth medium an the production of cell-bound staphylocoagulase. It was found that not only the amount of extracellular but also the amount of cell-bound staphylocoagulase was reduced considerably; however, the ratio extracellular/cell-bound staphylocoagulase had decreased only slightly (Table 1).

Release of cell-bound staphylocoagulase from washed cells

The nature of the bond between cell-bound staphylocoagulase and cell was studied by incubation of washed cells of 5 . aureus 104 with various agents under conditions in which the protein synthesis was abolished completely by chloramphenicol (data not shown). Incubation of washed cells with sodium chloride $(1,2,5,10$, 15 , and $24 \%$, potassium chloride (1M), magnesium chloride (1M), sodium citrate ( 5 and $10 \%$ ) and EDTA ( $5 \mathrm{mM}$ ) did not show any release of cell-bound staphylocoagulase. Incubation of the washed cells with Tris. $\mathrm{HCl}, \mathrm{pH}$ $7.4(1,2,5$ and $10 \%)$ revealed a release of $1,7,21$ and $37 \%$, respectively. A more effective release of staphylocoagulase could be obtained by incubation of the cells with $0.1 \%$ sodium deoxycholate or $1 \%$ Triton $X-100$, which gave a release of 48 and $93 \%$ respectively, indicating that the cell-bound staphylocoagulase was bound hydrophobically rather than ionically. The membrane penicillinase of B. licheniformis also is not released by high salt concentrations but can be extracted readily by detergents (Sargent and Lampen, 1970).

Localization of cell-bound staphylocoaqulase

In order to gain a better insight into the mechanism of the synthesis and secretion of staphylocoagulase it was necessary to determine where the cell-bound form was localized. The cellular distribution of staphylocoagulase in 5. aureus 104 is shown in Table 2. After preparation of protoplasts, it was observed that $81 \%$ of staphylocoagulase activity was associated with the protoplasts, whereas $21 \%$ was released and therefore located in the periplasmic space. When the protoplasts were osmotically shocked by resuspension in PBS and 
subsequently centrifuged, $69 \%$ of the staphylocoagulase activity remained in the particulate fraction and thus apparently membrane-bound. Staphylocoagulase activity in the supernatant i.e. the cytaplasm, could not be detected.

A direct lysis of the cells gave a slight increase of the staphylocoagulase activity. After centrifugation of the lysate, $63 \%$ of the activity was found in the membrane fraction, whereas in the supernatant fluids, (containing components of the periplasm plus cytoplasm), 20\% of the activity was recovered.

Table 2. Cellular distribution of staphylocoagulase in Staphylococcus aureus 104.

Localization of staphylocoagulase

Staphylocoagulase (units)
Recovery

(\%)
Cells

Protoplasts

Periplasm

Cell lysate

Cytoplasm

Membranes

1\% Triton $x-100$

membrane extract
6.74

100

5.48

BI

1.40

21

6.90

102

$<0.06$

$<1$

4.47

66

3.56

53

Extraction of the membrane fractions with $1 \%$ Triton $x-100$ gave a $53 \%$ recovery of the initial activity ( $80 \%$ of the nembrane-bound activity). The observed loss of about 20\% of the activity during the preparation of membranes, independent of the method used, was probably due to inactivation of the membrane-bound activity, since a direct extraction of whole cells with Triton $x-100$ gave a release of 93\%. The staphylocoagulase activity associated with the protoplasts and the membrane fractions also could be inhibited completely by antiserum to purified extracellular staphylocoagulase. 
Effect of cerulenin on the production of cell-bound and extracellular staphylocoaqulase

The production of the enterotoxins $A, B$ and $C$, $a$-haemolysin and staphylocoagulase by $\underline{S}$. aureus is inhibited completely by cerulenin at concentrations that do not affect growth (Altenbern, 1978 and Berkeley et al., 1978). The influence of cerulenin $(5 \mu \mathrm{g} / \mathrm{ml})$ on the production of cell-bound and extracellular staphylocoagulase in chemostat cultures of 5 . aureus 104 is shown in Fig. 1. The production of cell-bound staphylocoagulase was completely inhibited whereas the production of biomass was hardly affected. It should be noted that the amount of cell-bound staphylocoagulase decreased at a rate that was twice that of the theoretical wash-out. The latter rate of decay is to be expected when no de novo synthesis and no release of the cell-bound enzyme occurs. The production of extracellular staphylocoagulase was not inhibited instantaneously. After a delay of three hours, a complete inhibition occurred, resulting in a decrease of the concentration of extracellular staphylocoagulase that followed the theoretical wash-out curve. However, the production of total extracellular protein was not affected negatively but even stimulated.

Effect of quinacrine on the production of cell-bound and extracellular staphylocoagulase

Quinacrine has been reported to interfere with the action of the penicillinase-releasing protease of $B$. licheniformis 749/C (Traficante and Lampen, 1977). The production of levansucrase by $B$. subtilis (Caulfield et al., 1979) and enterotoxin A by S. aureus (Berkeley et al., 1978) also is inhibited considerably by quinacrine. In chemostat cultures of $\mathrm{S}$. aureus 104 , the production of both extracellular and cell-bound staphylocoagulase were inhibited completely by quinacrine at a concentration of $0.1 \mathrm{mM}$. The production of biomass was slightly affected, whereas no effect on the production of total extracellular protein was observed. The increase in the production of cell-bound and extracellular staphylocoagulase, which occurred three hours after the addition of quinacrine was most probably due to dilution of the inhibitor (Fig. 2).

Although the penicillinase-releasing protease of B. licheniformis 749 has a narrow substrate specificity (Aiyappa and Lampen, 1977), its activity can be demonstrated with casein as the substrate (Aiyappa et al., 1977). However, cell-bound proteolytic activity as well as proteolytic activity in cell lysates of 5 . aureus 104 


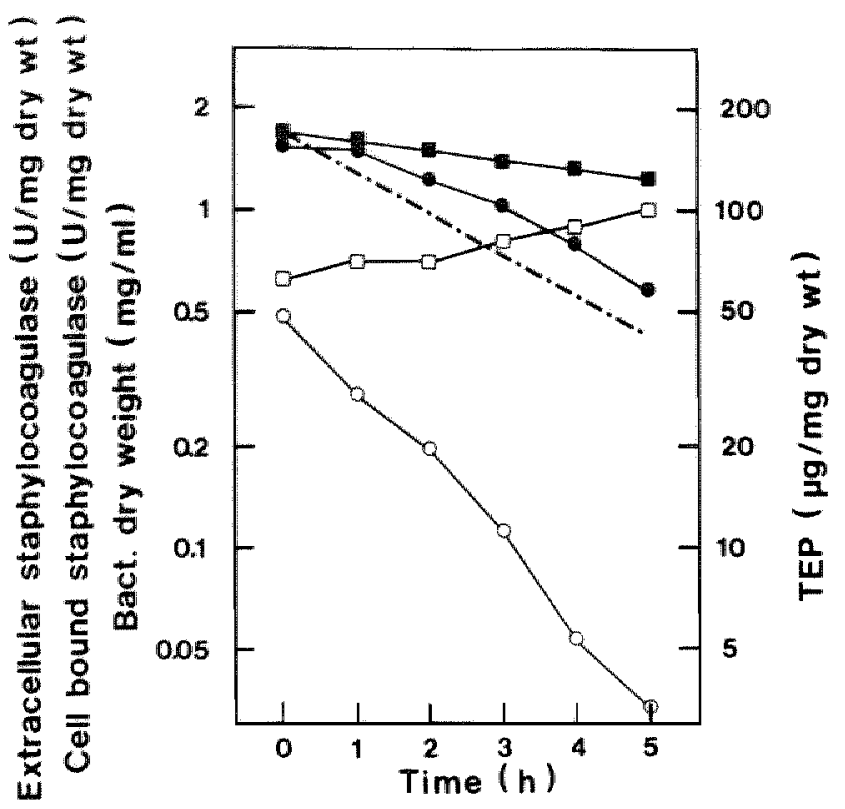

Fig. I Influence of cervlenin on the production of extracellular and cell-bound ataphylocoagulase, total extracellular protein and biomass in a chemostat culture of $S$. aureus $104\left(\mathrm{D}=0.28+0.01 \mathrm{~h}^{-1}, 30^{\circ} \mathrm{C}, 400\right.$ $\mathrm{rpm})$. Cerulenin was added to the fermenter at time zero to a final concentration of $5 \mu \mathrm{g} / \mathrm{ml}$. ( - ) extracellular staphylacoagulase, ( 0 ) cell-bound staphylocoagulase, ( $\mathbf{\text { a }}$ bacterial dry weight, ( $\square$ ) total extracellular protein (TEP), (-*) theoretical washout of non-growing organisms at $\mathrm{D}=0.28 \mathrm{~h}^{-1}$.

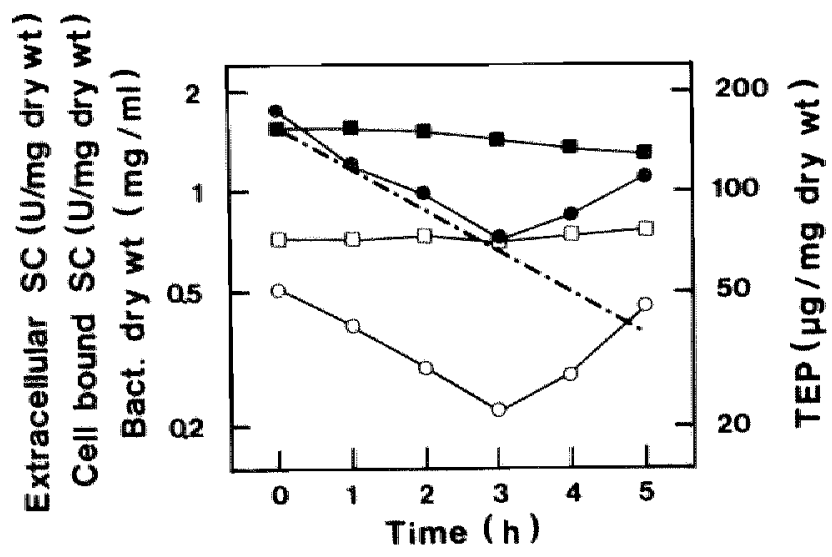

Fig. 2 Influence of quinacrine on the production of extracellular and cell-bound staphylocoagulase, total extracellular protein and biomass in a chemostat culture of 5 . aureus $104\left(0=0.28+0.01 \mathrm{~h}^{-1}, 30^{\circ} \mathrm{C}, 400\right.$ rpm). quinacrine was added to the fermenter at time zero to a $f$ inal concentration of $0.1 \mathrm{mM}$. ( ) extracellular staphylocoagulase, ( $O$ ) cell-bound staphylocaagulase, (a) bacterial dry weight, ( $\square$ ) total extracellular protein (TEP), (- - - - ) theoretical wash-out of nongrowing organisms at $D=0.28 \mathrm{~h}^{-1}$. 
could not be demonstrated with azocasein in the presence of $2 \mathrm{mM} \mathrm{CaCl} \mathrm{Cl}_{2}$ (data not shown).

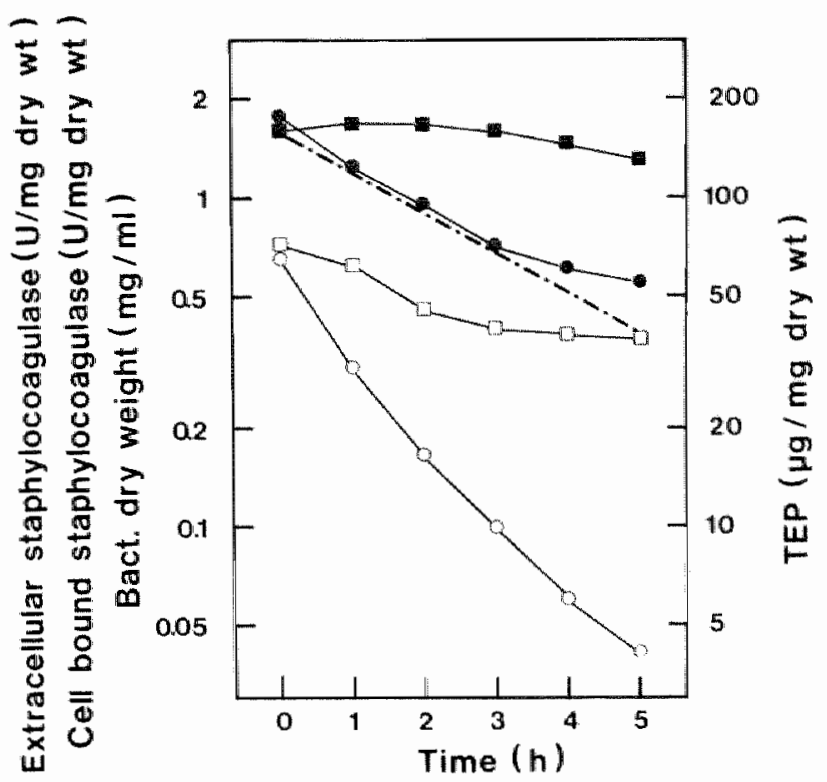

Fig. 3 Influence of lincamycin on the production of extracellular and cell-bound staphylocoagulase, tatal extracellular protein and biomass in a chemastat culture of 5 . aureus $104 \quad \mathrm{CD}=0.28+0.01 \mathrm{~h}^{-1}, 30^{\circ} \mathrm{C}, 400$ rpm). Lincomycin was added to the fermenter at time zero to a final concentration of $20 \mu \mathrm{g} / \mathrm{ml}$. (-) extracellular staphylocoagulase, ( 0 ) cell-bound staphylocoagulase, ( $)$ bacterial dry weight, ( $\square$ ) total extracellular protein (TEP), (-.-) theoretical wash-out of nongrowing organisms at $D=0.28 \mathrm{~h}^{-1}$.

Effect of lincomycin and chloramphenicol on the production of cell-bound and extracellular staphylocoagulase

Although the involvement of a lipid intermediate/exoprotein releasing protease system has been accepted generally as a mechanism in the export of exoproteins, it was remarkable that in this study cerulenin and quinacrine did not affect the production of total extracellular protein. Therefore, the "classical" inhibitors of protein synthesis lincomycin and chloramphenicol were used in order to study their effect on the production of total extracellular protein, extracellular and cellbound staphylocoagulase. Addition of lincomycin to a final concentration of $20 \mu \mathrm{g} / \mathrm{ml}$, completely inhibited the production of cell-bound and extracellular staphylocoagulase, whilst the production of total extracellular protein was inhibited for more than $80 \%$ (Fig. 3). The 


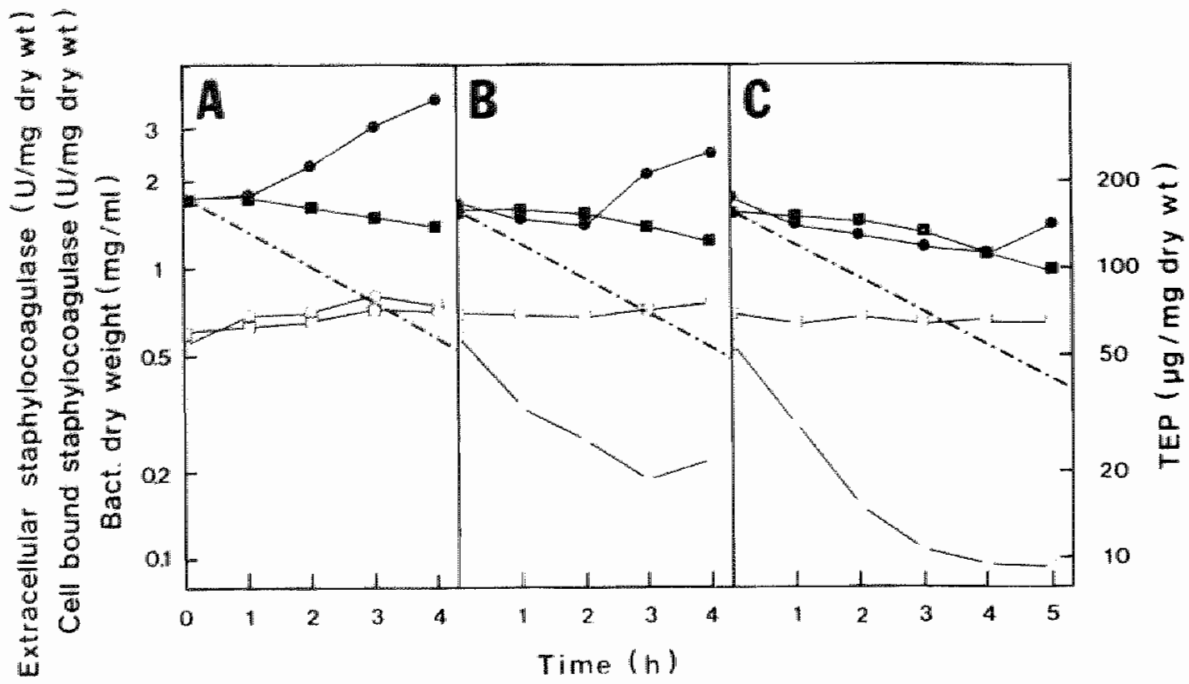

Fig. 4 Influence of chloramphenicol on the production of extracellular and cell-bound staphylocoagulase, total extracellular protein and bionass in a chemostat culture of 5 . aureus $104\left(\mathrm{D}=0.28+0.02 \mathrm{~h}^{-1}, 30^{\circ} \mathrm{C}\right.$, $400 \mathrm{rpm})$. Chloramphenicol was added to the fermenter at time zero to final concentrations of $5 \mu \mathrm{g} / \mathrm{ml}$ (A), $10 \mu \mathrm{g} / \mathrm{ml}$ (B) and $20 \mu \mathrm{g} / \mathrm{ml}$ (C), resp. (-) extracellular staphylocoagulase, ( 0 ) cell-bound staphylocoagulase, ( ) bacterial dry weight, ( $\square$ ) total extracellular protein (TEP), (--) theoretical wash-out of non-growing organisms at $\mathrm{D}=0.28 \mathrm{~h}^{-1}$.

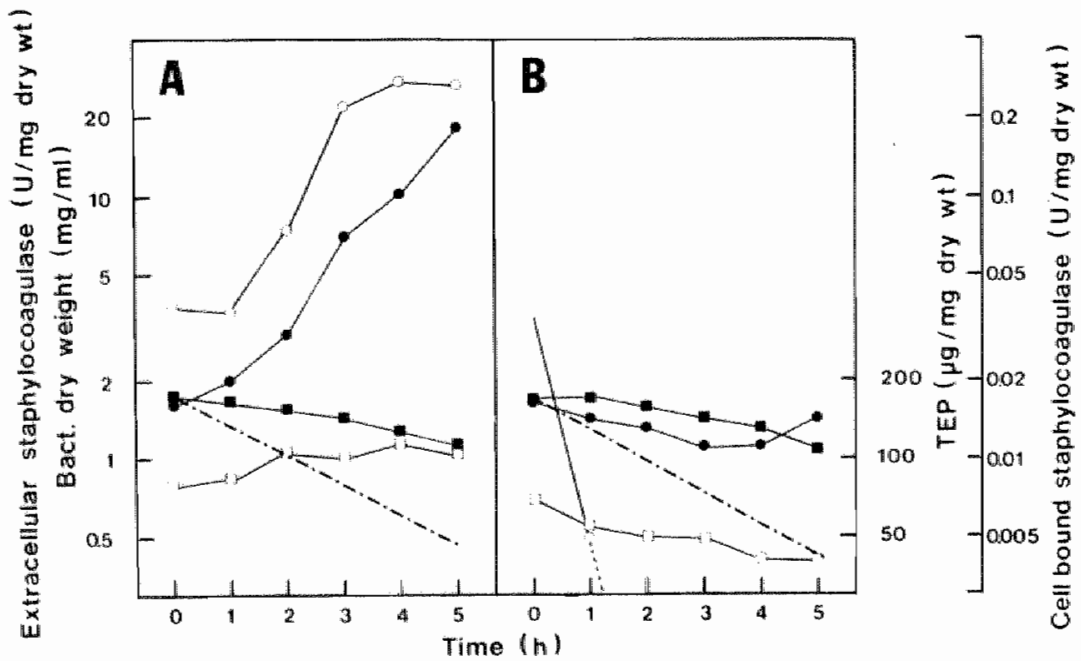

Fig. 5 Influence of chloramphenical on the production of extracellular and cell-bound staphylocoagulase, total extracellular protein and biomass in a chemostat culture of 5 . aureus growing in the presence of $2 \% \mathrm{NaCl}\left(\mathrm{D}=0.28+0.01 \mathrm{~h}^{-1}, 30^{\circ} \mathrm{C}, 400 \mathrm{rpm}\right)$. Chloramphenicol was added to the fermenter at time zero to final concentrations of $5 \mu \mathrm{g} / \mathrm{ml}$ (A) and $20 \mu \mathrm{g} / \mathrm{ml}$ (B), resp. (O) extracellular staphylocoagulase, (O) cellbound staphylocoagulase, ( ) bacterial dry weight, ( $)$ ) total extracellular protein (TEP), (- - - theoretical wash-out of nongrowing organisms at $D=0.28 \mathrm{~h}^{-1}$. 
amount of cell-bound staphylocoagulase decreased at a rate 2.3 times that of the theoretical wash-out, similar to the rate observed with cerulenin treatment (Fig. 1).

The effect of various concentrations of chloramphenicol on the production of cell-bound and extracellular staphylocoagulase, and of total extracellular protein was very remarkable. At a concentration of $5 \mu \mathrm{g} / \mathrm{ml}$ chloramphenicol, a considerable stimulation of the production of extracellular staphylocoagulase took place; the production of cell-bound enzyme and total extracellular protein had increased to a lesser extent (Fig. 4A). In batch cultures of S. aureus 104, however, an almost complete inhibition of the production of extracellular staphylocoagulase was observed at a chloramphenicol concentration of $5 \mu \mathrm{g} / \mathrm{ml}$ (data not shown). When the initial concentration of chloramphenicol was raised to $10 \mu \mathrm{g} / \mathrm{ml}$, a complete inhibition of the production of cell-bound staphylocoagulase was observed (Fig. 4B). The amount of cell-bound staphylocoagulase decreased much more rapidly than the theoretical washout rate. The production of extracellular staphyloco-agulase was only inhibited during the first two hours of incubation. A subsequent stimulation (comparable to that in Fig. 4A) then occurred after a prolonged incubation time, in which the chloramphenicol concentration had decreased to approximately $5 \mu \mathrm{g} / \mathrm{ml}$, due to wash-out of the antibiotic. Finally, a concentration of $20 \mu \mathrm{g} / \mathrm{ml}$ chloramphenicol enhanced the rate of decrease of cellbound staphylocoagulase to the same extent as was observed in the case of cerulenin and lincomycin. The inhibition of the production of extracellular staphylocoagulase increased to 100\% in the first hour and took place over a prolonged incubation time (Fig. 4C). At concentrations of 10 and $20 \mu \mathrm{g} / \mathrm{ml}$ chloramphenicol, almost no effect on the production of total extracellular protein was observed. Continuous addition of chloramphenicol leading to a constant concentration of the antibiotic in the vessel was not possible because a considerable wash-out of the culture occurred, as can be seen already in the experiments depicted in Fig. 4, after an incubation time of $4-5 \mathrm{~h}$.

Since an addition of $2 \% \mathrm{NaCl}$ to the growth medium influenced the ratio of extracellular/cell-bound staphylocoagulase (Table 1), it was of interest to study the effect of chloramphenicol under these growth conditions. It can be seen in Fig. $5 \mathrm{~A}$ that an initial concentration of $5 \mu \mathrm{g} / \mathrm{ml}$ chloramphenicol gave an enormous stimulation of the production of cell-bound and extracellular sta- 
phylocoagulase and almost a doubling of the production of total extracellular protein. When the initial chloramphenicol concentration was $20 \mu \mathrm{g} / \mathrm{ml}$, the amount of cell-bound staphylocoagulase decreased very rapidly and disappeared almost completely (Fig. 5B). The production of total extracellular protein decreased considerably (comparable with the inhibition by lincomycin, Fig. 3). The production of extracellular staphylocoagulase decreased almost to the same extent as in the absence of 2\% NaCl (Fig. 5B). The degree of inhibition of the biomass production by chloramphenicol was not influenced by the addition of $2 \% \mathrm{NaCl}$.

\section{DISCUSSION}

The results of the present investigation have resolved the controversy over the existence of an intracellular or cell-bound staphylocoagulase. Besides an extracellular staphylocoagulase, a cell-bound staphylocoagulase was produced in considerable amounts in chemostat cultures of 5 . aureus 104 , under magnesium- and oxygen-limited growth conditions (Table 1). It has to be mentioned that a cell-bound staphylocoagulase could be detected not only in strain 104, but also in various other 5 . aureus strains. It is probable that the failure in the past to demonstrate cell-bound staphylocoagulase has been caused by the use of cells that did not possess high amounts of the enzyme, along with methods of staphylocoagulase assay that lacked sufficient sensitivity. Although Blobel and Bermann (1960) indeed demonstrated the presence of cell-bound staphylocoagulase by means of immunofluorescence techniques, aspecific binding of the conjugate to protein A (see Forsgren and Sjöquist, 1966) cannot be ruled out in their experiments, since it is not clear from their published data whether the staphylocoagulase-negative $\underline{S}$. aureus strain was devoid of protein A. Treatment of washed cells with various agents suggested that the cell associated staphylocoagulase was bound hydrophobically. From the cellular distribution study (Table 2), it can be concluded that the cell-bound staphylocoagulase was predominantly (about B0\%) membrane-bound; the remaining part was demonstrated to be present in the periplasmic space whereas cytoplasmic staphylocoagulase could not be detected. Moreover, treatment of the membranes with Triton $X-100$ resulted in an almost complete release of staphylocoagulase. 
Since the cell-bound staphylocoagulase was related antigenically to the extracellular staphylocoagulase and was linked hydrophobically to the cell-membrane, just like the membrane-penicillinase of B. licheniformis, it was reasonable to postulate that the cell-bound form was an intermediate in the secretion process of staphylocoagulase. Therefore, we studied the influence of various inhibitors of the synthesis and secretion processes on the production of cell-bound and extracellular staphylocoagulase.

The pattern of inhibition of cell-bound and extracellular staphylocoagulases, in the presence of cerulenin, was as expected when the synthesis of the cellbound form was inhibited completely. Thus, the cellbound staphylocoagulase already formed will be transformed very rapidly into the extracellular form, resulting in a delayed inhibition of production of the extracellular staphylocoagulase (Fig. 1).

However, recent investigations on the structure of cellbound penicillinase of B. licheniformis (Lampen, 1980 and Simons et al., 1978) revealed that a covalently bound phospholipopeptide is not present but that the membrane-penicillinase contains an amino-terminal peptide extension, hydrophobic in character. Moreover, the production of staphylococcal enterotoxin $B$ by nongrowing cells (Altenbern, 1978), and the production of hyaluronidase by $\underline{5}$. aureus 722 (Berkeley and Pepper, 1979), cannot be inhibited by cerulenin. Therefore, doubts have been raised about the role of the phospholipid protein intermediates in the export of exoproteins and about the generality of the proposed mechanism. Alternatively, cerulenin might have affected staphylocoagulase levels through non-specific alterations of the membrane backbone, as proposed by Fishman et al. (1978) in the case of levansucrase by $B$. subtilis, leading to an impeded insertion or transfer of the enzyme molecules through the membrane.

The production of extracellular staphylocoagulase could be inhibited completely by quinacrine suggesting that a proteolytic cleavage step might well be involved in the secretion of staphylocoagulase (Fig. 2). In this connection, it is rather remarkable that the production of cell-bound staphylocoagulase was inhibited completely. However, the rate of decrease of cell-bound staphylocoagulase was considerably lower than that observed in Fig. 1. Therefore, it is likely that a feed-back regulatory mechanism is present.

In general, the use of quinacrine in experiments in- 
volving intact cells can be criticised. Although quinacrine is a potent inhibitor of the penicillinasereleasing protease in B. Iicheniformis, other effects of this compound in biological systems also have been described (reviewed by Sargent, Gosh and Lampen, 1968). Thus, quinacrine is known not only as an inhibitor of many flavine-containing enzymes, adenosine triphosphatases, glucose-6-phosphatase and esterases, but also as an uncoupler of oxidative and photophosphorylation. since the energy-state of the cell is of great importance in the regulation of production of staphylocoagulase (Engels et al., 1980), the inhibitory effect of quinacrine might be explained on the basis of its ability to uncouple oxidative phosphorylation in $\underline{\mathrm{S} \text {. aureus }}$ 104.

No explanation can be given for the absence in 5. aureus 104 of a proteolytic enzyme necessary to remove the hydrophobic tail of the cell-bound staphylocoagulase, unless this protease has an unusually narrow substrate specificity. Therefore, further investigations will be necessary to assess the role of such a releasing enzyme in the secretion process of staphylocoagulase and of exoproteins in general.

Although both chloramphenicol and lincomycin affect protein synthesis at the ribosomal level, it can be seen that their effects on the production of cell-bound and extracellular staphylocoagulase, and on total extracellular protein, were rather different (Figs. 3 and 4). Gemmell and Shibl (1976) reported that, in batch cultures of $\mathrm{S}$. aureus, the production of staphylocoagulase and total extracellular protein were inhibited for 100 and $50 \%$, respectively, by lincomycin at concentrations which did not impair growth by more than 20\%. In contrast, chloramphenical inhibited the production of staphylocoagulase only partially while the production of total extracellular protein was not at all inhibited.

The two-fold increase in the rate of decrease of cell-bound staphylocoagulase, compared with that of the decrease of extracellular staphylocoagulase (following the theoretical wash-out rate), in the presence of lincomycin (Fig. 3), supported again the proposal that cell-bound staphylocoagulase is a precursor of extracellular staphylocoagulase in the secretion process. The effects of chloramphenicol on the production of cell-bound and extracellular staphylocoagulase were difficult to interpret. An extra problem in these experiments was that the growth was affected considerably at the chloramphenicol concentrations used. 
It $c$ an be argued that the membrane-bound $x$ ibosomes might be less susceptible to chloramphenicol than the cytoplasmic ribosomes. Thus, low concentrations of chloramphenicol will inhibit the production of cytoplasmic proteins (and partially the growth) and consequently stimulate the production of extracellular proteins. Indeed, this phenomenon can be seen in Fig. 4A. In the other hand, an increase in the chloramphenicol concentration did inhibit the production of cell-bound staphylocoagulase substantially (comparable with the inhibition by lincomycin); however, the production of extracellular staphylocoagulase was inhibited for only 33\%, whereas the production of total extracellular protein was not affected (Figs. $4 \mathrm{~B}$ and $4 \mathrm{C}$ ).

In Table 1 , it can be seen that the addition of $2 \%$ $\mathrm{NaCl}$, did not influence the production of extracellular staphylocoagulase in contrast to the amount of cellbound staphylocoagulase which had decreased almost 16-fold. An increase of the salt concentration generally increases hydrophilic binding to the membrane. Thus, it is probable that the number of hydrophobic anchor places for cell-bound staphylocoagulase had decreased. Therefore, when the cell-bound form is considered as a precursor of extracellular staphylocoagulase, then the turn-over of this precursor has to increase considerably, resulting in a decrease of the steady-state concentration of this protein. Because of this high turnover of cell-bound staphylocoagulase, under these growth conditions, it is conceivable that addition of chloramphenicol at a stimulatory concentration of 5 $\mu \mathrm{g} / \mathrm{ml}$ will lead to a substantial increase of the concentration of cell-bound and extracellular staphylocoagulase (Fig. 5A). On the other hand, when chloramphenicol was added at an inhibitory concentration of $20 \mu \mathrm{g} / \mathrm{ml}$, a dramatic decrease of the cell-bound concentration will be seen, accompanied by a decrease in the production of extracellular staphylocoagulase (Fig. 5B). In the latter case also a decrease in the production of total extracellular protein was observed. Thus, it seemed as if the addition of $2 \% \mathrm{NaCl}$ to the growth medium, yielded cells in which the turn-over of cellbound staphylocoagulase, and that of precursors of total extracellular protein, had increased, resulting in an increased susceptibility to chloramphenicol. Nevertheless, more data about the kinetics of the secretion process itself are needed in order to explain the observed phenomena.

Finally, it has been shown that the membrane phopho- 
lipid composition in bacilli can be caused to vary extensively by the growth conditions, and that especially under magnesium-limited growth conditions at neutral $\mathrm{pH}$, the content of positively charged lipids is decreased considerably (Minnikin and Abdolrahimzadeh, 1974). Thus, the addition of $400 \mu \mathrm{M} \mathrm{MgCl}_{2}$ to the growth medium (Table 1) might have decresed the membrane permeability of S. aureus 104 towards cell-bound staphylocoagulase, resulting in a diminished secretion of the protein.

In summary, we conclude that the hydrophobic cellbound staphylocoagulase is a precursor in the production of extracellular staphylocoagulase. The effects of cerulenin, quinacrine, lincomycin and chloramphenicol on the production of cell-bound and extracellular staphylocoagulase supported this hypothesis and were in agreement with other observations on other exoproteins. However, with respect to the production of total extracellular protein, it can be concluded that the proposed secretion model for exoproteins, in which a lipid intermediate/exoprotein-releasing protease mechanism is involved, is rather speculative because no influence of cerulenin and of quinacrine could be demonstrated. In order to elucidate the mechanism of secretion of total extracellular protein, and of staphylocoagulase in particular, a complete characterization of the cellbound precursor(s) and releasing protease(s) is essential before any conclusion can be drawn.

\section{ACKNOWLEDGEMENTS}

We wish to thank Dr. J.T.M. Wouters for helpful discussions and Dr. O.M. Neijssel for critically reading the manuscript.

\section{REFERENCES}

Aiyappa, P.S., and Lampen, J.0. 1977. Penicillinasereleasing protease of Bacillus licheniformis 749. Specificity for hydroxyamino acids. J. Biol. Chem. 252: $1745-1747$.

Aiyappa, P.S., Traficante, L.J., and Lampen, J.0. 1977. Penicillinase-releasing protease of Bacillus licheniformis: purification and general properties. $].$ Bacteriol. 129: 191-197.

Altenbern, R.A. 1966. On the nature of albumin-promoted coagulase release by Staphylococcus aureus. J. Infect. Dis. 116: 593-600. 
Altenbern, R.A. 1977. Extreme sensitivity of staphylococcal enterotoxin $B$ and $C$ production to inhibition by cerulenin. Antimicrob. Agents Chemother. 11: 906908.

Altembern, R.A. 1978. Protease inhibitors suppress enterotoxin $B$ formation by staphylococcus aureus. FEMS Microbiol. Lett. 3: 199-202.

Berkeley, R.C.W., Pepper, E.A., Caulfield, M.P., and Melling, J. 1978. The inhibition of Staphylococcus aureus enterotoxin A production by cerulenin and quinacrine; presumptive evidence for a lipid intermediate/protease release mechanism. FEMS Microbiol. Lett. 4: 103-105.

Berkeley, R.C.W., and Pepper, E.A. 1979. The effect of cerulenin on exoprotein production by bacteria; are lipoprotein intermediates involved in export? Soc. Gen. Microbiol. Quarterly 6: 170-171.

Blobel, H., and Berman, D.T. 1960. Serologic studies of purified staphylocoagulase with special reference to fluorescence microscopy. J. Immunol. 85: 244-249.

Caulfield, M.P., Berkeley, R.C.W., Pepper, E.A., and Melling, J. 1979. Export of extracellular levansucrase by Bacillus subtilis: inhibition by cerulenin and quinacrine. J. Bacteriol. 138: 345-35l.

Duthie, E.S., and Haughton, G. 1958. Purification of free staphylococcal coagulase. J. Gen. Microbiol. 70: 125-134.

Engels, W., Kamps, M.A.F., and Van Boven, C.P.A. 1978. Influence of cultivation conditions on the production of staphylocoagulase by Staphylococcus aureus 104. J. Gen. Microbiol. 109: 237-243.

Engels, W., Kamps, M.A.F., and Van Boven, C.P.A. 1980. Continuous culture studies on the production of staphylocoagulase by 5 taphylocaccus aureus. Antonie van Leeuwenhoek 46: 533-550.

Fahlberg, W.J., and Marston, J. 1960. Coagulase production by Staphylococcus aureus. I. Factors influencing coagulase production. J. Infect. Dis. 106: 111115 .

Fishman, Y., Rottem, S., and Citri, N. 1978. Evidence linking penicillinase formation and secretion to lipid metabolism in Bacillus licheniformis. J. Bacteriol. 134: 434-439.

Forsgren, A., and Sjöquist, J. 1966. Protein A from 5 . aureus. I. Pseudoimmune reactions with human $y$-globulins. J. Immunol. 97: 822-827. 
Gemmell, C.G., and Shibl, A.M.A. 1976. The control of toxin and enzyme biosynthesis in staphylococci by antibiotics. p. 657-664. In J. Jeljaszewicz, (ed.), Staphylococci and staphylococcal diseases. Gustav Fischer Verlag, Stuttgart.

Hazen, G.G., Hause, J.A., and Hubicki, J.A. 1965. An automated system for the quantitative determination of proteolytic enzymes using azocasein. Ann. N.Y. Acad. Sci. 130: 761-768.

Herbert, D., Phipps, P.J., and Strange, R.E. 1971. Chemical analysis of microbial cells. Methods in Microbiology 5B: 209-344.

Hudson, L., and Hay, F.C. 1976. In Practical immunology. Blackwell Scientific Publication, 0xford.

Igarashi, H., Morita, T., and Iwanaga, S. 1979. A new method for purification of staphylocoagulase by a bovine prothrombin-sepharose column. J. Biochem. 86: 1615-1616.

Lampen, J.0. 1978. Phospholipoproteins in enzyme excretion by bacteria. p. 231-247. In R.Y. Stanier, H.J. Rogers, and J.B. Ward, (eds.), Relations between structures and function in the prokaryotic cell. 28th Symp. Soc. Gen. Microbiol., Cambridge University Press, London.

Lampen, J.0., Nielsen, J.B.K., Izui, K., and Caulfield, M.P. 1980. Bacillus licheniformis $\beta$-lactamases: multiple forms and their roles. Phil. Trans. R. Soc. Lond. B 289: 345-348.

Lazdunski, A., Murgier, M., and Lazdunski, C. 1979. Phospholipid synthesis-dependent activity of aminopeptidase $N$ in intact cells of Escherichia coli. J. Mol. Biol. 128: 127-141.

Lowry, 0.H., Rosenbrough, N.J., Farr, A.L., and Randall, R.J. 1951. Protein measurements with the Fol in phenol reagent. J. Biol. Chem. 193: 265-275.

Minnikin, D.E., and Abdolrahimzadeh. 1974. Effect of $\mathrm{pH}$ on the proportions of polar lipids, in chemostat cultures of Bacillus subtilis. J. Bacteriol. 120: $999-1003$.

Dmura, S. 1976. The antibiotic cerulenin, a novel tool for biochemistry as an inhibitor of fatty acid synthesis. Bacteriol. Rev. 40: 681-697.

Sargent, M.G., and Lampen, J.0. 1970. Organization of the membrane-bound penicillinase in Bacillus licheniformis. Arch. Biochem. Biophys. 136: 167-177. 
Sargent, M.G., Ghosh, B.K., and Lampen, J.0. 1968. Characteristics of penicillinase release by washed cells of Bacillus licheniformis. J. Bacteriol. 96: $1231-1239$.

Simons, M., Sarvas, M., Garoff, H., and Helenius, A. 1978. Membrane-bound and secreted forms of penicillinase from Bacillus licheniformis. J. Mol. Biol. 126: $673-690$.

Traficante, L.J., and Lampen, J.0. 1977. Vesicle penicillinase of Bacillus licheniformis: Existence of periplasmic-releasing factor(s). J. Bacteriol. 129: 184-190.

Yamamoto, S., and Lampen, J.0. 1976a. Purification of plasma membrane penicillinase from Bacillus licheniformis $749 / \mathrm{C}$ and comparison with exoenzyme. J. Biol. Chem. 251: 4095-4101.

Yamamoto, S., and Lampen, J.0. 1976b. The hydrophobic membrane penicillinase of Bacillus licheniformis $749 / C$. Characterization of the hydrophilic enzyme and phospholipeptide produced by trypsin cleavage. J. Biol. Chem. 251: 4102-4110.

Yamamoto, S., and Lampen, J.0. 1976c. Membrane penicillinase of Bacillus licheniformis $749 / \mathrm{C}$ : sequence and possible repeated tetrapeptide structure of the phospholipopeptide region. Proc. Natl. Acad. Sci. U.S.A. 73: 1457-1461. 
THE COMPETITIVE ABILITY OF SPONTANEOUS STAPHYLOCOAGULASE-NEGATIVE MUTANTS OF STAPHYLOCOCCUS AUREUS 104 AND NCTC 8178 WITH RESPECT TO GROWTH OF THE PARENT STRAINS IN CONTINUOUS CULTURE

\section{SLMMARY}

During the prolonged cultivation of $\mathbf{S}$. aureus, strains 104 and NCTC 8178, in continuous culture, staphylocoagulase-negative mutants arose and accumulated progressively in increasing proportions. The resulting loss of production of staphylocoagulase was accompanied by a simultaneous loss of production of $\alpha$-haemolysin and leucocidin. Characterization of the strains revealed no further differences in biotype, exoenzymes, phage pattern and plasmid content. Cultivation in batch cultures showed that the maximal specific growth rates and specific oxygen consumption rates of the mutant strains were slightly higher than those of the parent strains, whereas the production of total extracellular protein of the mutant strains had decreased significantly. From competition experiments between parent and mutant strains in chemostat cultures at different dilution rates and cultivation temperatures, it was concluded that the underlying mechanism of accumulation of staphylocoagulase-negative mutants in the chemostat is based on differences in affinity for the limiting substrate(s) rather than on differences in the production rates of total extracellular proteins. The complete repression of three exoenzymes, a partial repression of the total extracellular protein production and an increased affinity for the limiting substrate(s) suggested that a mutation in a regulatory gene is involved. The possible role of a transposon in this mutation is discussed.

\section{INTRODUCTION}

In the taxonomy of staphylococci, great importance has been attributed to the ability to produce staphylocoagulase (Baird-Parker et al., 1976; Kloos and Schleifer, 1975). However, various authors have reported the spontaneous loss of the staphylocoagulase character 
(Duthie and Haughton, 1958; Korman, 1963; Tager, 1974). On the other hand Lotter and Genigeorgis (1977) described spontaneous variants from staphylocoagulase-negative enterotaxigenic staphylococci which had gained the ability to produce staphylocoagulase as well as DNase and a -haemolysin. Tager (1974) suggested that the loss of staphylocoagulase production was due generally to point mutations. Studies, in which the loss or recovery of the staphylocoagulase character was obtained by lysogenic conversion, transduction or mutagenic agents, revealed not only correlations with the loss or recovery of the production of several extracellular enzymes but also with colony form, pigmentation, sensitivity to typing phages, antibiotic resistance, alterations in cell wall composition and the ability to produce acid from a wide variety of sugars (Duval-Iflah et al., 1977; Forsgren et al., 1971; Korman, 1963; Omenn and Friedman, 1970; Yoshikawa et al., 1974). However, the combinations of genetic characters lost or recovered together were different from report to report.

Therefore, it has been postulated, mainly on the basis of studies with pleiotropic exoprotein-negative mutants, that the simultaneous loss or recovery of these characters is due to repression or activation of a common regulatory locus (Björklind and Arvidson, 1980; Forsgren et al., 1971; Omenn and Friedmann, 1970; Yoshikawa et al., 1974).

Models for the regulation of exoprotein biosynthesis at transcriptional level have been formulated by Björklind and Arvidson (1980) and by Coleman, Brown and Stormonth (1975).

It was reported previously (Engels, Kamps and Van Boven, 1980) that during prolonged cultivation of $\mathrm{S}$. aureus, strains 104 and NCTC 8178, under magnesium- and oxygen1 imited chemostat growth conditions (optimal for staphylocoagulase production), staphylocoagulase-negative mutants invariably appeared, and out-grew the staphylocoagulase-producing population to more than 90\%. Since staphylocoagulase is considered to be an important virulence factor of $S$. aureus and a major character in the classification of staphylococci, we undertook a detailed investigation into the characteristics of these mutant strains and their competitive ability with respect to their parent strains in chemostat cultures when growing under different conditions. The results, contained in this paper indicate that the pattern of regulation of the production of exoproteins by these staphylocoagulase-negative strains are not compatible with the 
proposed models. The probable nature of this mutation and its role in the regulatory mechanism underlying extracellular protein production are discussed.

MATERIALS AND METHODS

Organisms

Staphylococcus aureus, strains 104 and NCTC 8178 were maintained on nutrient agar slopes by monthly subculture. The staphylocoagulase negative $\left(\mathrm{SC}^{-}\right)$mutants were isolated from chemostat cultures after prolonged cultivation under magnesium- and axygen-limited growth conditions, as described previously (Engels et al., 1980).

Growth conditions

Batch cultures were grown in $100 \mathrm{ml}$ erlenmeyer flasks containing $20 \mathrm{ml}$ casein hydyrolysate, yeast extract or Brain Heart Infusion (BHI) medium in a G-25 rotary shaker (New Brunswick Scientific Co., New Brunswick, N.J., U.S.A.) at 190 rpm as previously described (Engels, Kamps and Van Boven, 1978). The incubation temperature was $30^{\circ} \mathrm{C}$ unless otherwise indicated.

Continuous cultures of 5 . aureus were maintained in casein hydrolysate medium in Bioflo C30 chemostats (New Brunswick 5ci. Co. Inc., New Brunswick, N.J., U.S.A.) as described by Engels et al. (1980). The pH was maintained at a value of 7.4 by means of an automatic titrator with $2 \mathrm{M} \mathrm{KOH}$ as the titrant. The temperature was held at $30^{\circ} \mathrm{C}$, except otherwise stated. The stirrer speed was 400 rpm and the culture volume was $320 \mathrm{ml}$. Silicone antifoaming agent (purchased from BDH) was added automatically at regular time intervals.

Competition experiments in continuous culture

Steady-state cultures of the staphylocoagulase-positive $\left(\mathrm{SC}^{+}\right) \mathrm{S}$. aureus strains were inoculated with S. aureus $5 C$ to a final level of about 5\%. Subsequently samples were taken at $3 \mathrm{~h}$ intervals during the first 12 hours of growth and at 9-15 h intervals during the following period. After appropriate dilution in $0.15 \mathrm{M}$ $\mathrm{NaCl}, 0.1 \mathrm{ml}$-samples were plated on Brain Heart Infusion agar (Difco) plates containing $10^{\%}(\mathrm{v} / \mathrm{v})$ citrated human plasma. After $18 \mathrm{~h}$ growth at $37^{\circ} \mathrm{C}$, the percentage $5 \mathrm{C}^{+}$ cells in the original samples were estimated from the colony counts. The specific growth rate $(\mu)$ of the uncompetitive 5 . aureus $\mathrm{SC}^{+}$population was calculated using the modified washout growth rate equation from 
Jannash (1969) as described by Godwin and Slater (1979): $\mu=\left[\left(\ln x_{t}-\ln x_{0}\right) / t_{2}-t_{1}\right]+D$, where $x_{0}$ and $x_{t}$ are the initial and the final population sizes at times $t_{1}$ and $t_{2}$, respectively, and $D$ is the dilution rate maintained during the competition experiment.

Production of revertants

Revertants were produced by treatment of the $\mathrm{SC}^{-}$ strains, grown in yeast extract medium, with ethylmethanesulfonate (EMS, Sigma) according to Stobberingh and Winkler (1977).

Analytical procedures

Bacterial dry weight was measured by the procedure of Herbert et al. (1971).

Total extracellular protein was determined, after overnight dialysis of culture supernatants against double glass distilled water at $0-4^{\circ} \mathrm{C}$, according to Lowry et al. (1951).

Maximal specific growth rates $\left(\mu_{\max }\right)$, specific oxygen consumption rates $\mathrm{QO}_{2} \quad(\mu \mathrm{I}$ oxygen consumed/mg dry weight.h) and the production rates of total extracellular protein in batch cultures were measured as follows. Casein hydrolysate medium was inoculated with an 1 in 200 inoculum of overnight cultures and incubated at $30^{\circ} \mathrm{C}$ as described above. Growth was followed by measuring the culture density spectrophotometrically at 540 $\mathrm{nm}$ at 30 min intervals. At the end of the logarithmic phase, the cultures were centrifuged for $20 \mathrm{~min}$ at 15000 g. The amount of total extracellular protein was measured in the supernatants; the sediments were washed twice with $50 \mathrm{mM}$ Tris $\mathrm{HCl}$, $\mathrm{pH} \mathrm{7.4.} \mathrm{The} \mathrm{oxygen} \mathrm{consumption} \mathrm{of}$ the washed cells was measured in a Gilson oxygraph with a Clark electrode in a mixture containing $50 \mathrm{mM}$ Tris. $\mathrm{HCl}, \mathrm{pH} 7.4$ and $50 \mathrm{mM}$ mannitol at $30^{\circ} \mathrm{C}$. The amount of biomass was determined by dry weight measurement.

Staphylocoagulase (produced in casein hydrolysate medium) was determined as described previously (Engels et al., 1978) by means of a clotting assay with human, rabbit, pig, cow, chicken and dog plasma, respectively. Clotting times up to 4 hours were marked as a positive reaction. Staphylocoagulase positive reactions were only found with human, rabbit and pig plasma.

Heemolysin (produced in BHI medium) was assayed with human, rabbit, and sheep erythrocytes according to Goode and Baldwin (1973). The haemolytic activity of both strains with rabbit, sheep and human erythrocytes was 200,350 and $50 \mathrm{U} / \mathrm{ml}$, respectively. Therefore, it was 
possible that the strains produced a mixture of different haemolysins. However, the haemolytic activity met the criteria of Wiseman (1975) for $\alpha$-haemolysin (and not for $\beta-, \gamma-$ and $\delta$-haemolysin) and was completely abolished by anti $(x$-haemolysin (purchased from Behring Werke AG, Marburg, $W$. Germany). This led us to the conclusion that the haemolytic activity was due exclusively to $\alpha$-haemolysin activity and that the remarkable reaction pattern with the different erythrocytes was caused probably by interference of other extracellular products, present in the culture supernatants (Elek and Levy, 1954; Rogolsky, 1979).

Leucocidin (produced in yeast extract medium) was determined with human leucocytes according to Gladstone and Van Heijningen (1957) as described by Van der Vijver (1972).

Protein A was determined with the Aurea A-kit provided by Bio Mérieux (Charbonnières-les-Bains, France).

Protease, Penicillinase, DNase, Lipases (hydrolysis of Tween 20, 40, 60 and 80, respectively), Staphylokinase, Crystal violet reaction and phage typing were carried out as described previausly (Engels et al., 1980).

Gelatinase was determined by the method of Clarke (1953).

Hyaluronidase was determined according to Smith and willett (1968).

Clumping factor was determined by the slide test as described by Cadness-Graves et al. (1943).

Catalase activity was determined by adding a few drops of culture in a drop of $3 \% \mathrm{H}_{2} \mathrm{O}_{2}$. Rapid appearance and sustained production of gas bubbles was indicative of a positive reaction.

Plasmids were isolated and characterized according to Wilson, Tatten and Baldwin (1978).

Tellurite reduction and Egg Yolk clearance were determined on Baird-Parker Medium (Oxoid) plates containing $50 \mathrm{ml}$ Egg-Yolk Tellurite emulsion (Oxoid) per litre. Lysozyme $(50 \mu \mathrm{g} / \mathrm{ml})$ and lysostaphin $(50 \mu \mathrm{g} / \mathrm{ml})$ susceptibility were determined as described by Heckzo, Grov and Pulverer (1976).

Penicillin, cephalosporin and novobiocin susceptibility was tested by the routine diffusion plate technique on D.S.T. agar (Oxoid) with the following antibiotics discs (Neo-Sensitabs, provided by A/S Roxo, Toastrup, Denmark): penicillin low (13 $\mu \mathrm{g}$ per disc), penicillin high ( $165 \mu \mathrm{g}$ per disc), cephalosporin ( $66 \mu$ ger disc) and novobiocin (100 $\mu$ g per disc).

Aerobic production of acid from D-glucose, D-fructose, 
D-mannose, maltose, lactose, D-trehalose, D-mannitol, xylitol, D-melibiose, raffinose, D-xylose, saccharose, $x$-methyl glucoside, $\mathbb{N}$-acetyl glucosamine, production of acetoin, phosphatase, arginine-dehydrolase, urease and the reduction of nitrate were determined by means of the API Staph system (principally based on the scheme of Kloos and Schleifer, 1975) provided by API System S.A. (La Balme-les-Grottes, France).

Aerobic production of acid from D-glucose (also anaerobic), D-mannitol (also anaerobic), lactose, maltose, D-arabinose, D-galactose, D-mannose, D-trehalose, D-xylose, saccharose, production of acetoin, arginine dehydrolase, urease, phosphatase and the reduction of nitrate were also determined by the tube methods according to Baird-Parker (1963).

RESULTS

Accumulation of $\mathrm{SC}^{-}$-mutants in the chemostat

Steady-state chemostat cultures of $S$. aureus strains 104 and NCTC 8178 were grown at dilution rates between 0.1 and $0.5 \mathrm{~h}^{-1}$. After a period of 150-250 hours, depending on the growth rate, the amount of staphylocoagulase decreased logarithmically with a half-life of 8-24 hours. Samples taken during this decline were plated on Brain Heart Infusion agar containing human plasma and it could be shown that the decrease of staphylocoagulase production was due to an accumulation of staphylocoagulase-negative mutants. Plating these samples on blood agar plates, indicated that the production of haemolysin was lost simultaneously. It must be mentioned that the moment of appearance of the staphylocoagulase-negative cells was unpredictable and occurred in spite of extensive cloning of the wild type strains on Brain Heart Infusion agar plates containing plasma before inoculation of the chemostat. In batch cultures, $\mathrm{SC}^{-}$cells were observed only after prolonged subcultivation with relatively small inocula (see also Duthie and Haughton, 1958; Tager, 1974).

The accumulation of these mutants suggested that the $\mathrm{SC}^{-}$ cells had a significant growth advantage over the $\mathrm{SC}^{+}$ cells so that they could outgrow the original $\mathrm{SC}^{+}$population.

In order to obtain more information about the nature and the origin of this growth advantage, an extensive characterization of the parent strains and their mutants was carried out. 
Table 1. Biochemical characters of the 5 . aureug strains and their staphylocoagulase-negative mutants.

\begin{tabular}{|c|c|c|c|c|}
\hline \multirow{2}{*}{ 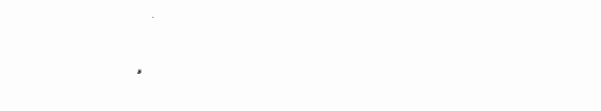 } & \multicolumn{2}{|c|}{ Strain 104} & \multicolumn{2}{|c|}{ Strain NCTC 8178} \\
\hline & $\mathrm{Sc}^{+}$ & $5 c^{-}$ & $\mathrm{SC}^{+}$ & $\mathrm{SC}^{-}$ \\
\hline : & & & & \\
\hline Phage group & III & III & $I / I I I I$ & $I / I I I I$ \\
\hline Plasmids & IGMD & $16 \mathrm{MD}$ & 30MD & 30MD \\
\hline Cristal wiolet reaction & $C / D$ & $C / D$ & $\mathrm{C} / \mathrm{D}$ & $C / D$ \\
\hline Protein A & + & + & + & + \\
\hline Tellurite Egg Yolk reaction & $*$ & + & - & - \\
\hline Pigment (yellow) & + & + & + & + \\
\hline Lysozym-susceptibility & - & - & - & - \\
\hline Lysostaphin-susceptibility & + & + & + & + \\
\hline Penicillin-susceptibility & + & + & - & - \\
\hline Cephalosporin-susceptibility & + & + & + & + \\
\hline Novobiocin-susceptibility & + & + & + & + \\
\hline Voges-Proskauer & + & + & + & + \\
\hline Nitrate-reduction & + & + & + & + \\
\hline Catalase & + & + & + & + \\
\hline Urease & + & + & + & + \\
\hline Arginine hydrolase & + & + & + & + \\
\hline Production of acid from: & & & & \\
\hline D-glucose (aerobic and anaerobic) & + & + & + & + \\
\hline D-mannitol (aerobic and anaerobic) & + & + & + & + \\
\hline D-Mannose & + & + & + & + \\
\hline Maltose & + & + & + & + \\
\hline Lactose & + & + & + & + \\
\hline D-Trehalose & + & + & + & + \\
\hline D-Melibiose & - & - & - & - \\
\hline xylital & - & - & - & - \\
\hline Raffinose & - & - & - & $=$ \\
\hline $0-x y$ lose & - & - & - & - \\
\hline Saccharose & + & + & + & + \\
\hline$a$-Methylglucoside & - & - & - & - \\
\hline$N$-Acety 1 -glucosamine & + & + & + & + \\
\hline D-Fructose & + & + & + & + \\
\hline D-Arabinose & - & - & - & - \\
\hline D-Galactose & + & + & + & + \\
\hline
\end{tabular}


Characterization of the 5. aureus strains

Table 1 shows a large number of biochemical characters of the parent and mutant strains that were examined. The phage groups of parent and mutant strains were identical. Strain 104 and its mutant were sensitive to phage 77 (phage group III), whereas strain NCTC 8178 and its mutant were sensitive to the phages 29,52 (phage group I) and the phages $53,54,75,77,84$ and 85 (phage group III).

It has been reported that phage conversion can be responsible for the loss of the ability to produce staphylocoagulase (Duval-Iflah et al., 1977; Jollick, 1972; Korman, 1963). Since these conversions were accompanied by a change in sensitivity to typing phages, it is very unlikely that in the 5 . aureus strains, described in this study, the loss of staphylocoagulase production was due to the loss of a prophage.

An analysis of the plasmid contents revealed that the parent strains and its mutant contained identical plasmids in similar amounts.

The remaining characters, like biochemical reactions, susceptibility to lysozyme, lysostaphin and antibiotics, and the fermentation of a variety of sugars did not reveal any difference between parent and mutant strains. An analysis of the exoproteins produced, indicated that, besides staphylocoagulase and $\alpha$-haemolysin, leucocidin production also was lost (Table 2). Hyperproduction of other exoproteins, as was reported for specific exoprotein-negative strains by Björklind and Arvidson (1980), Coleman (1981) and Yoshikama et al. (1974), was

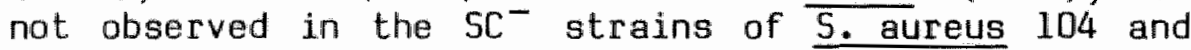
NCTC 8178.

Determination of the maximal growth rates in batch cultures in $1 \%$ casein hydrolysate medium at $30^{\circ} \mathrm{C}$ (Table 3 ) showed an increase of $\mu_{\max }$ of about $10 \%$ for the mutant strain with a concomitant increase of $6-10 \%$ in the specific oxygen consumption rate.

However, the production of total extracellular protein had decreased considerably ( 34 and $58 \%$ for strains 104 and NCTC 8178, respectively).

\section{Production of revertants}

Various authors reported that the loss of acquisition of several exoenzymes was due to a mutation in a single locus and therefore revertable by nitrosoguanidine or ethylmethylsulphonate (EMS) (Björklind and Arvidson, 1980; Forsgren et al., 1971; Omenn and Friedman, 1970; 
Table 2. Exoenzymes of the S. aureus strains and their staphylocoagulase-negative mutants.

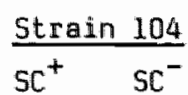

Staphy locoagulase

$a$-Haemolysin

Leucocidin

DNase

Penicillinase

Pratease

Lipases

Staphylokinase

Clumping factor

Phosphatase

Gelatinase

Hyaluronidase
Strain NCTC 8178

$\mathrm{SC}^{+} \mathrm{SC}^{-}$

\begin{tabular}{llll}
\hline+ & - & + & - \\
+ & - & + & - \\
+ & - & + & - \\
+ & + & + & + \\
- & - & + & + \\
- & - & - & - \\
+ & + & - & - \\
+ & + & + & + \\
+ & + & + & + \\
+ & + & + & + \\
+ & + & + & + \\
- & - & - & -
\end{tabular}

Table 3. Naximum growth rate, specific oxygen coneumption rate and total

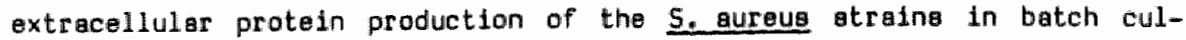
tures.

Strein

$$
\mu_{\max }\left(h^{-1}\right) \quad a_{\mathrm{O}_{2}}(\mu 1 / \mathrm{h} . \mathrm{mg} \text { dry wt }) \text { TEP ( } \mu \mathrm{g} / \mathrm{mg} \text { dry wt) }
$$

$\begin{array}{llrlrl}104\left(\mathrm{SC}^{+}\right) & 0.77 \pm 0.05)^{1} & 108 & \pm 5 & 59 \pm 8 \\ 104\left(\mathrm{SC}^{-}\right) & 0.84 \pm 0.05 & 115 & \pm 6 & 39 & \pm 6 \\ \text { NCTC } 8178\left(\mathrm{SC}^{+}\right) & 0.68 \pm 0.06 & 97 & \pm 7 & 125 & \pm 21 \\ \text { NCTC } 8178\left(\mathrm{SC}^{-}\right) & 0.75 \pm 0.07 & 112 & \pm 7 & 53 & \pm 8\end{array}$

)$^{2} n=5$ 


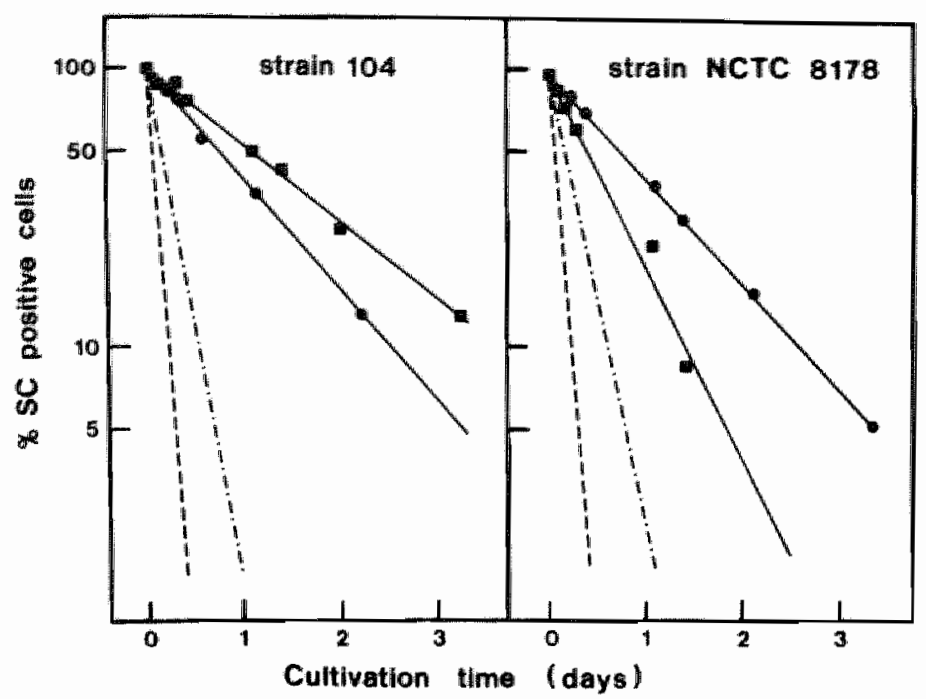

Fig. 1 Time courge of the competition between the parent and mutant strains of 5 . aureus 104 and NCTC 8178 , respectively. Cultures of the $\mathrm{SC}^{+}$straina growing in the chemostat at dilution rates of $0.17 \mathrm{~h}^{-1}$ and $0.50 \mathrm{~h}^{-1}$ were inoculated with $\mathrm{SC}^{-}$organisms to a level of $1 \% \mathrm{SC}^{-}$. (e) actual $10 s 8$ of $5 C^{+}$organisms at $0=0.17 \mathrm{~h}^{-1},(. .-$ ) theoretical washout of non-growing organisms at $D=0.17 \mathrm{~h}^{-1}$, ( $\left(\right.$ ) actual loss of $\mathrm{SC}^{+}$ orgenisms at $D=0.50 \mathrm{~h}^{-1},(--)$ theoretical wash-out of non-growing arganisms at $D=0.50 \mathrm{~h}^{-1}$.

Table 4. Competition experiments between staphylocoagulase-positive and staphylocoagulase-negative $\underline{S \text {. aureus }}$ strains at different dilution rates in chemostat cultures $\left(400 \mathrm{rpm}, 30^{\circ} \mathrm{C}\right)$.

Strain Dilution rate Specific growth rate $\mu$ Percentage decrease

$\begin{array}{lll}\left(h^{-1}\right) & \text { of the } S C \text { positive } & \text { of } \mu \text { for SC positive } \\ & \text { population } & \text { population }\end{array}$

\begin{tabular}{ccc}
\hline 0.17 & 0.13 & 21.9 \\
0.34 & 0.29 & 14.4 \\
0.50 & 0.47 & 5.4 \\
0.60 & 0.60 & 0.8 \\
0.70 & 0.70 & 0.0
\end{tabular}

NCTC 8178

$\begin{array}{lll}0.17 & 0.15 & 21.2 \\ 0.35 & 0.29 & 17.7 \\ 0.50 & 0.43 & 13.2 \\ 0.60 & 0.55 & 8.2 \\ 0.70 & 0.70 & 0.0\end{array}$


Yoshikawa et al., 1974). Several attempts were made with EMS as mutagenic agent to obtain $\mathrm{SC}^{+}$revertants from both of the $\mathrm{SC}^{-}$mutant strains. Only in a few cases were $\mathrm{SC}^{+}$revertants found, but after subculturing on $\mathrm{BHI}$ agar medium containing human plasma, $\mathrm{SC}^{+}$colonies could not be demonstrated indicating that these revertants did not possess a stable staphylocoagulase character. Reversion of the production of haemolysin and leucocidin was never observed. The lack of a selective medium needed to enrich the $\mathrm{SC}^{+}$cells was one of the major problems in these reversion experiments. In practice, it was not possible to screen more than about 30,000 colonies. Therefore, it is possible that revertants easily could have been missed when the frequency of reversion was low. Alternatively, the possibility that a single mutation is not involved at all, cannot be excluded.

Competition experiments between parent and mutant strains

Since the moment of appearance of the staphylocoagulase-negative cells in chemostat culture was unpredictable, the following approach was chosen. Continuous cultures of the $\mathrm{SC}^{+}$strains were set up and were deliberately contaminated with $\mathrm{SC}^{-}$cells as soon as the $\mathrm{SC}^{+}$ population had reached a steady-state.

In Fig. I the time course of these competition experiments at dilution rates of 0.17 and $0.50 \mathrm{~h}^{-1}$ are shown, Immediately after the addition of the $\mathrm{SC}^{-}$cells to $\mathrm{SC}^{+}$ steady state populations, the competitive advantage of the former was evident. The differences in the growth dynamics of the competing populations were the same as in chemostat cultures in which a spontaneous loss of staphylocoagulase production had occurred (half life of 8-24 hours). The competitiveness between the two populations expressed as percentage decrease in $\mu$ for the $\mathrm{SC}^{+}$ cells in relation to the dilution rate is shown in Table 4. At a dilution rate of $0.17 \mathrm{~h}^{-1}$ a considerable competition was observed. The competitiveness decreased with increasing dilution rates, whereas at a $D=0.70 \mathrm{~h}^{-1}$ (almost $\mu_{\max }$ ) no competition was evident. The influence of the cultivation temperature on the competitiveness is shown in Table 5. The $\mathrm{SC}^{+}$populations were grown at $\mathrm{a}$ dilution rate of $0.35 \mathrm{~h}^{-1}$. The decrease in numbers of $\mathrm{SC}^{+}$cells was followed at cultivation temperatures of $25,30,35$ and $40^{\circ} \mathrm{C}$, respectively. It can be seen that the competitiveness increased with increasing temperatures. Generally, the decrease in $\mu$ for the $\mathrm{SC}^{+}$cells in these competition experiments was of the same magnitude 
Table 5. Competition experiment between staphylocoagulase- positive and ataphylocoagulase-negative 5 . aureus atrains at different temperatures in chemostat cultures $\left(D=0.35+0.01 \mathrm{~h}^{-1}, 400 \mathrm{rpm}\right)$.

Strain

Temperature

$\left({ }^{\circ} \mathrm{C}\right)$
Percentage decrease of $\mu$

for SC positive population
104

25

30

35

40

NCTC 8178
0.5

14.4

18.0

26.3

10.2

17.7

23.2

26.0

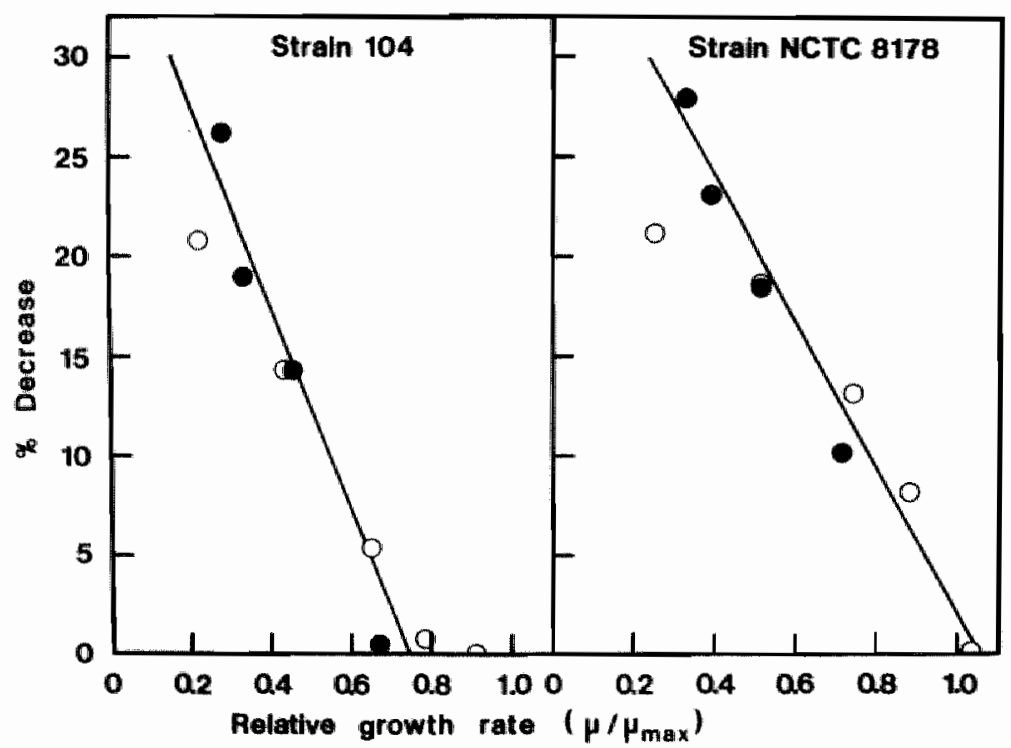

Fig. 2 The relation between the percentages decrease of $\mu$ for the $\mathrm{SC}^{+}$ population of S. aureus strain 104 and NCTC B178, respectively and their relative growth rates. The percentages decrease of $\mu$ for the $\mathrm{SC}^{+}$ cells at different dilution rates (O) and at different temperatures (-) were abtained from Tables 4 and 5, respectively. 
of the increase in $\mu$ for the $\mathrm{SC}^{-}$cells (data not shown). In some experiments the $\mathrm{SC}^{+}$population did not disappear completely but persisted in the culture at a low percentage (about $1 \%$ ). This phenomenon may be due to wall growth or non-homogeneous conditions in the culture vessel (see also Godwin and Slater, 1979; Melling, Ellwood and Robinson, 1977; Wouters et al., 1980).

Tempest (1976) pointed out that growth rate per se is not a physiologically relevant parameter but merely one manifestation of the steady-state concentration of the growth limiting nutrient. An increase in the cultivation temperature generally leads to an increase in $\mu$ max, so that the concentration of the limiting nutrient(s) will decrease. Therefore, one can only compare two steadystate cultures growing at the same dilution rate when the steady-state concentrations of growth-limiting nutrient are approximately equal. Because of analytical difficulties, it is practically rather complex to obtain reliable data on the steady-state extracellular concentrations of growth-limiting nutrient at values close to the value of $K_{s}$ (the affinity constant for the limiting substrate). Therefore the concept of relative growth was employed as described by Evans (1976) and Tempest (1976). For this purpose the assumption is made that at the temperatures studied, $K_{s}$ remained constant. Subsequently the dilution rates were corrected for the maximal growth rates which were readily obtained from batch growth curves in casein hydrolysate medium at the different temperatures used (data not shown).

In Fig. 2, the competitiveness of both strains obtained from Tables 4 and 5 , were plotted against their "relative" growth rates; that is, the ratio of the imposed growth rate to the maximum growth rate $\left(\mu / \mu_{\max }\right)$. It can be seen that there is a rather close correlation in the range of relative growth rates between $0.30-0.70$ in the case of strain 104 and of $0.40-1.0$ for strain NCTC 8178. Thus, it seems reasonable to conclude that the influence of the temperature on the competitiveness indeed reflected an increase in $\mu_{\max }$, resulting in a decrease in the growth limiting nutrient concentration required to support growth at some sub-maximal value.

Influence of dilution rate on the total extracellular production of the parent and mutant strains

The specific rates of total extracellular protein production, as depicted in Fig. 3, increased linearly with increasing dilution rates. It can be calculated that the ratio of the production rates of the $\mathrm{SC}^{+}$and 
the $\mathrm{SC}^{-}$cells of both strains was rather constant in the range of the dilution rates studied. Since the competitiveness between the parent and mutant strains decreased with increasing dilution rates (Table 4), it is unlikely that the diminished total extracellular protein production played an important role in enhancing the growth advantage of $\mathrm{SC}^{-}$strains over the $\mathrm{SC}^{+}$strains.

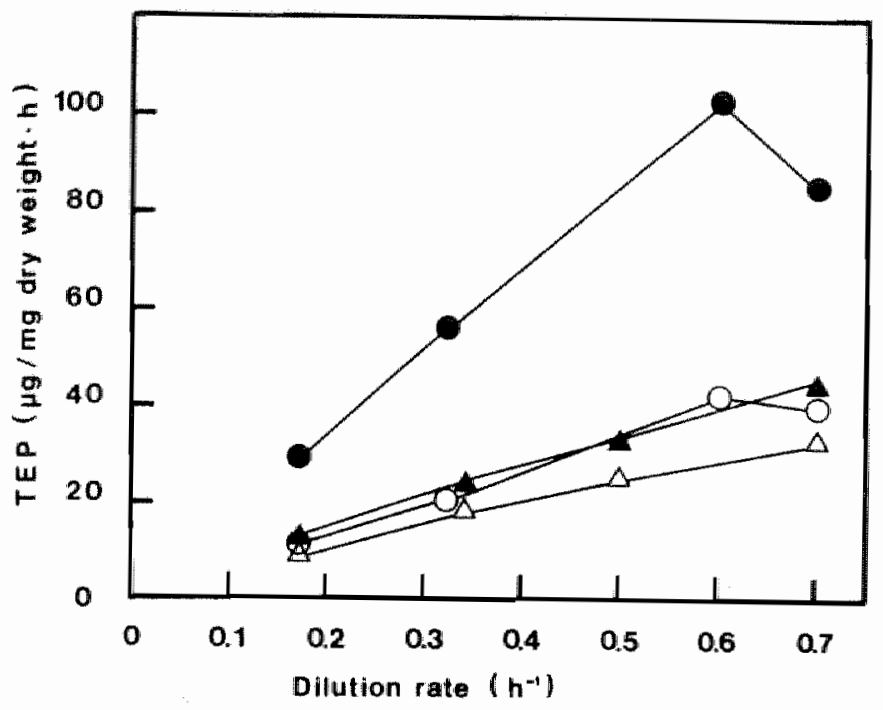

Fig. 3. Influence of the dilution rate on the specific rates of production of total extracellular protein (TEP) in chemostat cultures of the parent and mutant strains of S. aureus 104 and NCTC 8178, respectively. ( $\Delta$ ) 5 . aureus strain $104(\mathrm{SC}),(\Delta)$. aureus strain $104\left(\mathrm{SC}^{\circ}\right),(\mathrm{O})$ s. aureus strain NCTC $8178\left(\mathrm{SC}^{+}\right),(\mathrm{O}) \overline{5 \text {. Bureus }}$ strain $\mathrm{NCTC} 6178\left(\mathrm{SC}^{-}\right)$.

\section{DISCUSSION}

Cultivation of 5 . aureus strains 104 and NC TC 8178 in continuous culture gave rise to staphylocoagulasenegative $\left(\mathrm{SC}^{-}\right)$cells which subsequently accumulated by virtue of their apparent growth advantage under the imposed growth conditions. Characterization of these mutants revealed that they differed from their parent strains in only a few characters. Apart from a complete loss of ability to produce staphylocoagulase, $\alpha$-haemolysin and leucocidin (Table 2), the production of total extracellular protein had decreased considerably (Table 3, Fig. 3). In competition experiments, it was shown that the competitiveness between mutant and parent 
strain increased with decreasing dilution rates and with increasing cultivation temperatures (Tables 4 and 5). These data therefore raise two important questions: firstly, which factors are involved in promoting the observed growth advantage of the $\mathrm{SC}^{-}$over the $\mathrm{SC}^{+}$cells? And secondly, in what way does this mutation affect the regulatory mechanism of extracellular protein synthesis.

With regard to the first question, there are many factors that affect this growth advantage. One of these might be the excessive burden carried by the $\mathrm{SC}^{+}$cells in synthesizing considerable amounts of extracellular proteins. However, the competitiveness decreased with increasing dilution rates ( Table 4), in contrast to the production rate of total extracellular protein which increased with increasing dilution rates to the same extent for the mutant as well as the parent strains (Fig. 3). Thus, it is unlikely that this factor is of over-riding importance in the competition. Another factor might be the difference in maximum specific growth rate, as was observed by Godwin and Slater (1978) when studying the competition between plasmid-containing and plasmid-free cells. The slight increase in maximal growth rate and maximal oxygen consumption rate (Table 3) are not sufficient to account for the observed selection of $\mathrm{SC}^{-}$cells during the competition experiments in continuous culture. More decisive for the outcome of a competition experiment at submaximal specific growth rates, is the difference in affinity for the limiting substrate(s) of the competitors (Harder, Kuenen and Matin, 1977). The competition studies with the parent and mutant strains of $\mathrm{S}$, aureus 104 and NCTC 8178 showed that the growth advantage of the mutant strains increased with a decrease in the concentration of the growth limiting substrates, i.e. at low growth rates or, when the growth rate was kept constant, at high growth temperatures (Tables 4 and 5). This is illustrated clearly once again in Fig. 2, in which the competitiveness is plotted against the relative growth rate. Therefore, it is reasonable to conclude that an increased affinity for the limiting substrate is the decisive factor in the competition between the $\mathrm{SC}^{-}$and $\mathrm{SC}^{+}$cells.

In view of the strongly selective growth conditions occuring in chemostat cultures, it is clear why $\mathrm{SC}^{-}$ cells were not observed previously in batch cultures (Engels et al., 1978). During the exponential growth phase both populations coexisted and only at the end of this phase, the nutritional restriction became manifest, resulting in an increased competition between parent and 
mutant strain. Since the number of generations was low, due to relatively large inocula used, $\mathrm{SC}^{-}$cells were not observed. Therefore, $\mathrm{SC}^{-}$cells will only accumulate in batch cultures after prolonged subculturing, using very small inocula and high growth temperatures (Duthie and Haughton, 1958; Tager, 1974).

Coleman et al. (1975) postulated a regulatory model for exoenzyme biosynthesis in which the size of the pool of nucleic acid precursors controls exoprotein-associated RNA synthesis and thus exoenzyme formation. This accumulation of precursors is thought to be restricted to conditions of nutritional limitation, occurring in batch cultures after termination of exponential growth, and in chemostat cultures at submaximal dilution rates. Although this phenomenon was observed in batch cultures of S. aureus (Abbas-Ali and Coleman, 1977; Coleman and Abbas-Ali, 1977), it was demonstrated with chemostat cultures of Bacillus licheniformis $749 / \mathrm{C}$, and with several strains of 5 . aureus, that the production rate of total extracellular protein increased with increasing dilution ( $=$ growth) rate (Engels et al., 1980; Jarvis, Laurence and Pritchard, 1975; Wouters and Buysman, 1977 b). Furthermore, the observation of Coleman (1981) that the loss, or decrease, of the production of some exaproteins by pleiotropic mutants of $S$. aureus was compensated by an increase in the production of other exoproteins, so that the total production rate of exoprotein was not affected, could not be confirmed in this study. Therefore, an additional regulatory mechanism is necessary in order to understand why certain exoenzymes are only produced under certain conditions of nutritional limitation (see also Wouters and Buysman, 1977 a). A model that accounts for exoprotein synthesis during exoponential growth, as well as during post-exponential growth of 5 . aureus, was proposed by Björklind and Arvidson (1980). Factors like catabolite repression and end-product repression were also involved by introducing a signal substance $S$ (i.e. an intermediate metabolite) which activates a hypothetical protein EX. This protein which is supposed to be produced throughout the growth cycle, is needed in addition to the RNA polymerase for the transcription of structural and repressor genes.

The different patterns of exoprotein production in the spontaneous mutants of $\mathrm{S}$. aureus, strain V8 were explained in terms of different affinity between EX-S complex or EX-S-RNA polymerase and the individual promotor regions. These spontaneous mutations (probably in factor $\mathrm{EX}$ or in some enzyme involved in the synthesis of 5) 
could be reverted to the wild type in one step by treatment with NG. It was concluded therefore that the multiple changes of the mutants were due to a single mutation and that a superior/regulatory gene was involved. The decrease in the production of proteinases I and III, a-haemolysin, staphylokinase, DNase and phosphatase and the simultaneous increase of the production of staphylocoagulase and protein A could be explained with this model. The spontaneaus mutations in $S$. aureus strains 104 and NCTC 8178 yielded a simultaneous loss of staphylocoagulase, $\alpha$-haemolysin and leucocidin. Moreover, the total extracellular production rate had decreased considerably. Although a mutation in the regulatory gene is likely to be involved in these strains, it was impossible to obtain a reversion of these mutants to the wild strains with EMS.

Brown and Pattee (1980) reported that the spontaneous loss of $\alpha$-haemolysin production in various 5 . aureus strains also was not reversible with mutagenic agents, and that the loss of a prophage or a plasmid was not involved. From a detailed genetic study it was concluded that the regulation of $\alpha$-haemolysin production was located on a transposable genetic element. These elements can encode sequences that behave as transcriptional start and stap signals and can act as supernumerary regulation switches affecting gene repression. Furthermore, depending upon the orientation of the transposable element, the function of the mutated gene also may be abolished or, in addition, the expression of promotor distal genes in an operon can be either eliminated or enhanced. Therefore, transposable elements might be largely responsible for the spontaneous chromosomal alterations in many bactria (Kopecko, 1980). Although a detailed genetic analysis is necessary, the involvement of such an element in 5. aureus strains 104 and NCTC 8178 clearly would explain the size of the mutation (complete loss of three exoenzymes, decreased production rate of total extracellular protein and an increased affinity for the limiting substrates) and the fact that the observed mutation was not reversible with a mutagenic agent.

Generally, the presence of transposable genetic elements which may or may be not site specific, would provide in combination with phage conversion (Duval-Iflah et al., 1977; De Waard and Winkler, 1963) a framework to elucidate the widely described phenomenon of pleiotropy in 5 . aureus. 
Abbas-Ali, B., and Coleman, G. 1977. The characteristics of extracellular protein secretion by Staphylococcus aureus (Wood 46) and their relationship to the regulation of $\alpha$-toxin formation. J. Gen. Microbiol. 99: $277-282$.

Baird-Parker, A.C. 1963. A classification of micrococci and staphylococci based on physiological and biochemical tests. J. Gen. Microbiol. 30: 409-427.

Baird-Parker, A.C., Hil1, L.R., Kloas, W.E., Kocur, M., Deding, P., and Schleifer, K.H. 1976. Appendix 1. Identification of staphylococci. Subcommittee on the Taxonomy of Staphylococci and Micrococci. Int. J. Syst. Bacterial. 26: 333-334.

Björk1ind, A., and Arvidsan, S. 1980. Mutants of Staphylococcus aureus affected in the regulation of exoprotein synthesis. FEMS Microbiol. Letters 7: 203-206.

Cadness-Graves, B., Williams, R., Harper, G.J., and Miles, A.A. 1943. Slide test for coagulase positive staphylococci. Lancet 1: 736-738.

Clarke, S. 1953. A simplified plate method for detecting gelatin liquefying bacteria. J. Clin. Pathol. 6: 246248.

Coleman, G., Brown, S., and Stormonth, D.A. 1975. A model for the regulation of bacterial extracellular enzyme and toxin biosynthesis. J. Theor. Biol. 52: $143-148$.

Coleman, G., and Abbas-Ali, B. 1977. Comparison of the patterns of increase in $a$-toxin and total extracellular protein by Staphylococcus aureus (Wood 46) grawn in media supporting widely differing growth characteristics. Infect. Immun. 17: 278-281.

Coleman, G. 1981. Pleiotropic compensation in the regulation of extracellular protein formation by a low a-toxin producing variant of Staphylococcus aureus (Wood 46). J. Gen. Microbiol. 122: 11-15.

Duthie, E.S., and Haughton, G. 1958. Purification of free staphylococcal coagulase. J. Gen. Microbiol. 70: $125-134$.

Duval-Iflah, Y., Van Heyenoort, J., Rousseau, M., and Raibaud, P. 1977. Lysogenic conversion for multiple characters in a strain of Staphylococcus aureus. J. Bacteriol. 130: 1281-1291. 
Engels, W., Kamps, M.A.F., and Van Boven, C.P.A. 1978. Influence of cultivation conditions on the production of staphylocoagulase by Staphylococcus aureus 104. J. Gen. Microbiol. 109: 237-243.

Engels, W., Kamps, M.A.F., and Van Boven, C.P.A. 1980. Continuous culture studies on the production of staphylocoagulase by Staphylococcus aureus. Antonie van Leeuwenhoek 46: $533-550$.

Evans, C.G.T. 1976. The concept of relative growth rate. P. 346-348. In A.C.R. Dean, D.C. Ellwood, C.G.T. Evans, and J. Melling, (eds.), Continuous culture: application and new fields. Vol. 6 - Ellis Horwood, Chichester.

Elek, S.D., and Levy, E. 1954. The nature of discrepancies between haemolysins in culture filtrates and plate haemolysin patterns of staphylococci. J. Pathol. Bacteriol. 68: 31-40.

Forsgren, A., Nordström, K., Philipsen, L., and Sjöquist, J. 1971. Protein A mutants of Staphylococcus aureus. J. Bacteriol. 107: 245-250.

Gladstone, G.P., and Van Heijningen, W.E. 1957. Staphylococcal leucocidins. Br. J. Exp. Pathol. 38: 123131.

Godwin, D., and Slater, J.H. 1979. The influence of the growth environment on the stability of a drug resistance plasmid in E. coli K12. J. Gen. Microbiol. 1ll: $201-210$.

Goode, R.L., and Baldwin, J.N. 1973. Purification of staphylococcal alpha toxin by electrofocussing. Prep. Biochem. 3: 349-361.

Harder, W., Kuenen, J.G., and Matin, A. 1977. A review: Microbial selection in continuous culture. J. Appl. Bacteriol. 43: 1-24.

Heckzo, P.B., Grov, A., and Pulverer, G. 1976. Susceptibility of staphylococci of various cell wall structure to lysostaphin and its separated enzymes. p. 4348. In J. Jeljaszewicz, (ed.), Staphylococci and staphylococcal diseases. Gustav Fischer Verlag, Stuttgart.

Jannasch, H.W. 1969. Estimation of bacterial growth rates in natural waters. J. Bacteriol. 99: 156-160. Jollick, J.D. 1972. Evidence for bacteriophage conversion in Staphylococcus. Microbios. 6: 97-100. 
Kopecko, D.J. 1980. Involvement of specialized recombination in the evolution and expression of bacterial genomes. p. 165-205. In C. Stuttard and K.R. Rozee, (eds.), Plasmids and transposons. Environmental effects and maintenance mechanisms. Academic Press, New York.

Korman, R.Z. 1963. Coagulase-negative mutants of Staphylococcus aureus: genetic studies. J. Bacteriol. 86: 363-369.

Latter, L.P., and Genigeorgis, C.A. 1977. Isolation of coagulase-positive variants from coagulase-negative enterotoxigenic staphylococci. Zbl. Bakt. Hyg. I. Abt. Orig. A. 239: 18-30.

Melling, J., Ellwood, D.C., and Robinson, A. 1977. Survival of R-factor carrying Escherichia coli in mixed cultures in the chemostat. FEMS Microbiol. Letters 2: 87-89.

Omenn, G.S., and Friedman, J. 1970. Isolation of mutants of Staphylacoccus aureus lacking extracellular nuclease activity. J. Bacteriol. 101: 921-924.

Pattee, P.A., and Glaz, B.A. 1980. Identification of a chromosomal determinant of enterotoxin A production in Staphylococcus aureus. Appl. Envir. Microbiol. 39: $186-193$.

Rogolsky, M. 1979. Nonenteric toxins of Staphylococcus aureus. Microbiol. Rev. 43: 320-360.

Smith, R.F., and Willett, N.P. 1968. Rapid plate method for screening hyaluronidase and chondroitin sulphateproducing microorganisms. Appl. Microbiol. 16: 14341438.

Stabberingh, E.E., and Winkler, K.C. 1977. Restrictiondeficient Mutants of Staphylococcus aureus. J. Gen. Microbiol. 99: 359-367.

Tager, M. 1974. Current views on the mechanisms of coagulase action in blood clotting. Ann. N.Y. Acad. Sci. 236: 277-291.

Tenpest, D.W. 1976. The concept of relative growth rate: its theoretical basis and practical application. $p$. 349-352. In A.C.R. Dean, D.C. Ellwood, C.G.T. Evans, and J. Melling, (eds.), Continuous culture: application and new fields. Vol. 6. Ellis Horwood, Chichester.

Van der Vijver, J.C.M. 1972. Virulence factors with induced mutants of Staphylococcus aureus. Ph.D. Thesis. Erasmus University, Rotterdam. 
Van der Vijver, J.C.M., Van Es-Boon, M.M., and Michel, M.F. 1975. Induction of mutation in Staphylococcus aureus by ethylmethane sulphonate. J. Med. Microbiol. B: $265-277$.

Waart, J. de, Winkler, K.C., and Grootsen, C. 1962. Lysogenic conversion in staphylococci. Nature (London) 195: 407-408.

Wilson, C.R., Tatten, P.A., and Baldwin, J.N. 1978. Rapid procedure for the detection of plasmids in Staphylococcus epidermidis. Appl. Envir. Microbiol. 36: 368-374.

Wiseman, G.M. 1975. The haemolysins of Staphylococcus aureus. Bact. Rev. 39: 317-344.

Wouters, J.T.M., and Buysman, P.J. 1977 a. Production of some extracellular enzymes by Bacillus licheniformis $749 / \mathrm{C}$ in chemostat cultures. FEMS Micrabiol. Letters l: $109-112$.

Wouters, J.T.M., and Buysman, P.J. 1977 b. Secretion of penicillinase by Bacillus licheniformis $749 / \mathrm{C}$ in chemostat cultures. FEMS Microbiol. Letters l: $321-$ 324.

Yoshikawa, M., Matsuda, F., Naka, M., Murofishi, E., and Tsunematsu, Y. 1974. Pleiotropic alterations of activities of several toxins and enzymes in mutants of Staphylococcus aureus. J. Bacteriol. 119: 117-122. 


\section{RAPID AND DIRECT STAPHYLOCOAGULASE ASSAY THAT USES A CHROMOGENIC SUBSTRATE FOR IDENTIF ICATION OF STAPHYLOCOCCUS AUREUS}

\section{SUMMARY}

A rapid and direct assay of staphylocoagulase that uses chromogenic substrate Chromozym TH was developed for the routine identification of Staphylococcus aureus. False-positive and false-negative reactions were eliminated by measuring the activity of the staphylocoagulase-prothrombin complex directly. The method was compared with three clotting assays. The results show that the new assay is specific, quantitative, and easily automated. It offers clinical laborataries a more reliable assay of staphylocoagulase and is a valuable aid for the rapid identification of $\underline{5}$. aureus.

\section{INTRODUCTION}

The ability to produce staphylocoagulase is the most widely used and generally accepted criterion for identification of Staphylococcus aureus $(3,12)$. Most clinical laboratories perform a staphylocoagulase assay that is based on the ability of the enzyme to clot plasma. The clotting action of staphylocoagulase is due to a specific and stoichiometric reaction of staphylocoagulase with prothrombin, yielding a complex, i.e., staphylothrombin, which converts fibrinogen into insoluble fibrin in a manner similar to the action of physiologically formed thrombin $(10,23)$. Most assay methods routinely used are qualitative methods. Apart from difficulty in standardizing and quantitating these assays, false-negative and false-positive reactions may occur. False-negative reactions will take place if fibrinogen and fibrin are partially cleaved by proteases, staphylokinase-induced plasmin, or both, so that an insoluble fibrin clot cannot be formed or is dissolved (21). On the other hand, false-positive reactions are observed if prothrombin is activated by trypsin or papain-like proteases, which are present in the culture fluid of S. aureus (20). Recently, prothrombin activa- 
tion by metalloproteases has also been described (20). The present study describes a direct assay of the activity of staphylothrombin based on limited proteolysis of a synthetic chromogenic substrate. The method is quantitative and can be automated easily. A comparison of this method with "classic" clotting assays was made by using recently isolated clinical strains of $\mathbf{5}$. aureus.

MATERIALS AND METHDDS

Bacterial strains. 5. aureus strains $(n=70)$ recently isolated from various clinical sources were kindly provided by W.J. van Leeuwen, Department of Bacteriology, National Institute for Public Health, Bilthoven, The Netherlands. The strains were characterized as $\mathrm{S}$. aureus on the basis of phage and biotyping according to the method of Blair and Williams (4) and Kloos and Schleifer (12), respectively. For biochemical characterization, the API Staph system (API System S.A., La Balme les Grottes, France) was used. Another $20 \mathrm{clinical}$ isolates with the morphological characteristics of Staphylococcus spp. (yellow-white colonies with a smooth glistening surface and staining as gram-positive grapelike clusters) were also tested. These strains were nontypable with the International Phage Typing set and were not clearly identified to the species level according to the (restrictive) manufacturer's manual of the API 5taph system. For controls, the following staphylocoagulasenegative reference strains were used: Staphylocaccus haemolyticus SM102, Staphylococcus intermedius CF238, Staphylocaccus hyicus CBCC 1462 lobtained from W.E. Kloos, Department of Genetics, North Carolina State University, Raleigh), and Staphylococcus epidermidis 407 (obtained from J. Verhoef, Department of Medical Microbiology, University of Utrecht, The Netherlands).

Prothrombin-proconvertin-Stuart-Prower factor-antihemophilic factor B (PPSB). A concentrate of the blood clotting factors II, VII, $X$, and IX was prepared according to the method of Soulier et al. (16).

Cultivation conditions. The organisms were cultivated statically in test tubes ( 16 by $100 \mathrm{~mm}$ ) containing $5 \mathrm{ml}$ of nutrient broth (Difco Laboratories, Detroit, Mich.) or brain heart infusion medium (DifCo) at $37^{\circ} \mathrm{C}$ for $18 \mathrm{~h}$. Bovine serum albumin (Sigma Chemical Co., St. Louis, Mo.) was added to a final concentration of $0.2 \%$ (wt/vol) to these media to study its effect on staphylocoagulase production. 
Deoxyribonuclease. Deoxyribonuclease production was screened on agar plates containing $1 \%$ deoxyribonucleic acid (Difco), as described in the manufacturer's manual.

Protease. Protease production was determined with azocasein (Sigma) according to the method of Hazen et al. (9).

Staphylocoaqulase. Staphylocoagulase was produced from S. aureus strain 104, as described by Engels, Kamps, and Van Boven (6), and purified by chromatography on a bovine prothrombin-Sepharose $4 \mathrm{~B}$ affinity column according to the method of Igarashi, Morita, and Iwanaga (11).

Staphylocoaqulase assays.

(i) Chromogenic substrate method. After centrifugation of the cultures at $2,500 \times$ g for $15 \mathrm{~min}, 30 \mu 1$ of supernatant fluid was mixed with $120 \mu l$ of reagent mixture containing $72 \mathrm{mM}$ triethanolamine buffer ( $\mathrm{pH}$ 8.4), $144 \mathrm{mM} \mathrm{NaCl}, 166 \mu \mathrm{M}$ Chromozym TH (Boehringer, Mannheim, West Germany) and $5 \mu l$ of human PPSB solution containing $50 \mu \mathrm{g}$ of prothrombin per $\mathrm{ml}$ as the prothrombin source. In this assay, staphylocoagulase activates prothrombin to staphylothrombin. The thrombin-like activity of this complex cleaves the synthetic tripeptide Chromozym TH (N-Tosyl-glycyl-L-prolyl-L-arginyl-pnitroanilide.hydrochloride) by limited proteolysis, liberating the yellow p-nitroaniline $(18,22)$. The reaction was performed in microtiter plates (Greiner, Nuertingen, West Germany). After incubation for 1 and 2 $h$ at $37^{\circ} \mathrm{C}$, the absorbances were measured with a Titertek Multiskan (Flow Laboratories Ltd., Irvine, United Kingdom) at $405 \mathrm{~nm}$ and were corrected automatically for blank medium reactions. Since the staphylacoagulasenegative reference strains gave absorbances lower than 0.05 after $1 \mathrm{~h}$ of incubation, absorbances in the range of 0 to 0.05 were recorded as negative reactions, and absorbances exceeding the value of 0.05 were recorded as positive. One unit of staphylocoagulase was defined as the amount of enzyme giving an increase in absorbance at $405 \mathrm{~nm}$ of 1.0 per min at $37^{\circ} \mathrm{C}$.

(ii) Tube inoculation method. Twenty-five microliters of the culture fluid was inoculated into $0.5 \mathrm{ml}$ of citrated human plasma and incubated at $37^{\circ} \mathrm{C}$. After 1 and $4 \mathrm{~h}$, the mixtures were screened for clotting. Any degree of clotting constituted a positive reaction. Flocculent or fibrous precipitates were recorded as negative (13).

(iii) Tube supernatant fluid method. After centrifugation of the cultures at $2,500 \times \mathrm{g}$ for $15 \mathrm{~min}, 0.1 \mathrm{ml}$ of supernatant was mixed with $0.1 \mathrm{ml}$ of citrated human 


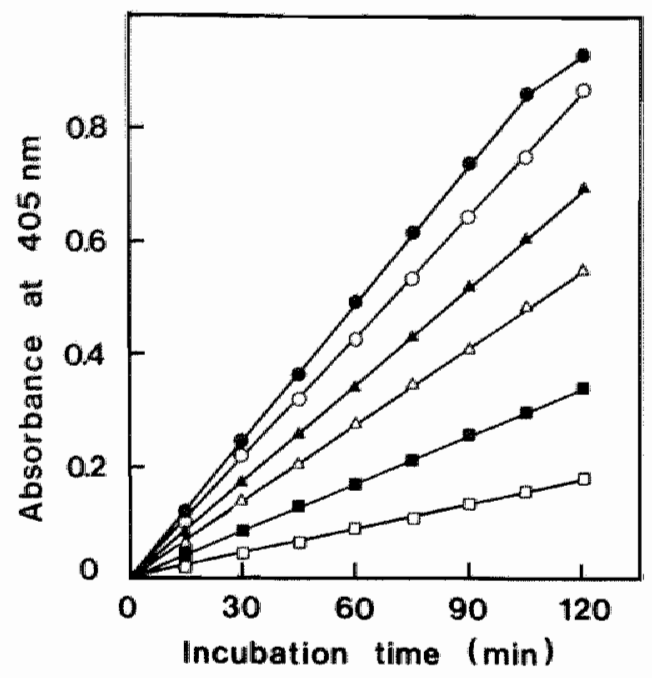

Fig. 1 Time courae of the hydrolysis of Chromozym TH with different amounts of staphylocoagulabe. The reactions were performed in microtiter plates at $37^{\circ} \mathrm{C}$ with different amounts of purified staphylocoagulase, as described in the text. The final concentrations in the reaction mixtures were: (c) $81 \mathrm{ng} / \mathrm{ml},(0) 68 \mathrm{ng} / \mathrm{ml}$, ( $) 54$

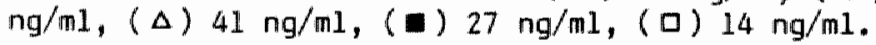

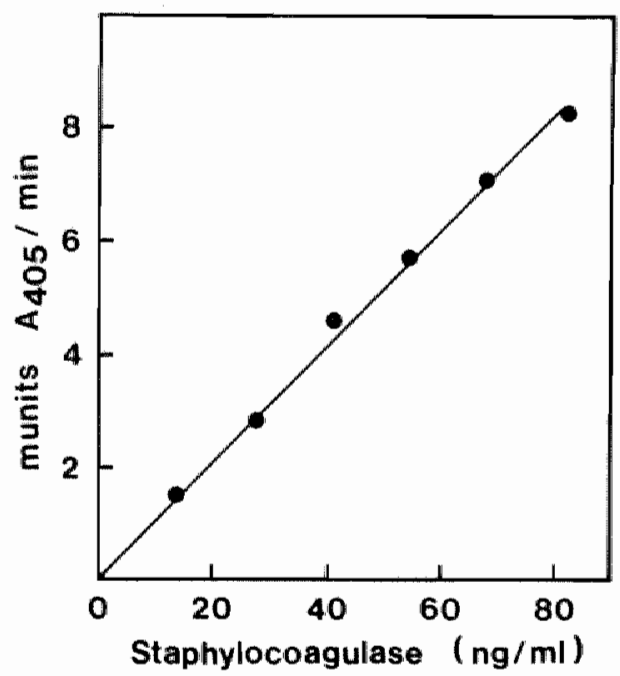

Fig. 2 Standard curwe of the linear relationship between the different ataphylocoagulase concentrations and their corresponding reaction rates, calculated from the time courses shown in Fig. 1. 
plasma and incubated at $37^{\circ} \mathrm{C}$. After 1 and $4 \mathrm{~h}$, the mixtures were screened for clotting according to the criteria described for the tube inoculation method.

(iv) Staphylocoagulase plates. In a method comparable to those described by Van der Vijver, Kraayeveld, and Michel (19) and Parisi, Baldwin, and Sottile (15), brain heart infusion agar plates containing $10 \%$ ( $\mathrm{vol} / \mathrm{voll}$ ) citrated human plasma were used. After inoculation and incubation at $37^{\circ} \mathrm{C}$, staphylocogulase production was indicated by opalescent haloes (diameter, 4 to $10 \mathrm{~mm}$ ) surrounding the colonies.

RESULTS

It has been shown previously (7) that a direct determination of staphylathrombin activity can be performed by using a chromogenic substrate. In this assay method a linear relationship was obtained not only between the incubation time and the hydrolysis of Chromozym TH with different amounts of purified staphylocoagulase (Fig. 1) but also between the concentrations of staphylocoagulase and their corresponding reaction rates (Fig. 2). Linearity of the activities was observed up to absorbances of 0.9 to 1.0 . In this experiment the amounts of purified staphylocoagulase were far in excess of what was found in the supernatant fluids of the staphylococcal cultures, which gave absorbances in the range of 0 to 0.5 .

The influence of the cultivation medium on the production of staphylacoagulase by the $S$. aureus strains $(n=70)$, when assayed by the chromogenic substrate and the tube clotting methods, is shown in Table 1. The percentages of staphylocoagulase-positive reactions of the tested strains, subcultured in brain heart infusion medium, were 84.3, 90.0 and $84.3 \%$ with the chromogenic substrate method, the tube incubation, and the tube supernatant fluid method as the respective assay methods. After a prolonged incubation time, the percentages increased to 97.1, 98.6, and 100\%, respectively. The staphylocoagulase production of one strain was variable and therefore resulted in a $98.6 \%$ - instead of a 100\% - positive score for the tested organisms. The amount of staphylocoagulase produced by the strains after subculturing in nutrient broth was much lower, resulting in only 10.0, 40.0 and $35.7 \%$ positive reactions, respectively, when the assay methods mentioned above were used. A longer incubation time resulted in an increase to $40.0,82.9$, and $88.6^{\mathrm{o}}$, respectively. 
For achieving high sensitivity of the assays, the amount of staphylocoagulase produced in the $18 \mathrm{~h}$ cultures had to be optimized. We achieved optimization by adding bovine serum albumin to a final concentration of $0.2 \%(w t / v a l)$, as recommended by Altenbern (2).

Table 1. Comparison of different assays of staphylocoagulase produced by seventy strains of $\underline{S}$. aureus in relation to various cultivation media.

$\%$ Positive staphylocoagulase reactions at indicated assay incubation time

$\begin{array}{ll}\text { Chromogenic Tube inocula- Tube supernatant } \\ \text { substrate } & \text { tion method method }\end{array}$
method

\begin{tabular}{|c|c|c|c|c|c|c|}
\hline Cultivation medium & $1 \mathrm{~h}$ & $2 \mathrm{~h}$ & $1 \mathrm{~h}$ & $4 \mathrm{~h}$ & $1 \mathrm{~h}$ & $4 h$ \\
\hline Brain heart infusion & 84.3 & 97.1 & 90.0 & 98.6 & 184.3 & 100 \\
\hline $\begin{array}{l}\text { Brain heart infusion } \\
+0.2 \% \text { bovine gerum } \\
\text { albumin }\end{array}$ & 98.6 & 98.6 & 97.1 & 100 & 98.6 & 98.6 \\
\hline Nutrient broth & 10.0 & 40.0 & 40.0 & 82.9 & 35.7 & 88.6 \\
\hline $\begin{array}{l}\text { Nutrient broth } \\
+0.2 \% \text { bovine serum } \\
\text { albumin }\end{array}$ & 74.3 & 97.1 & 54.3 & 87.1 & 52.9 & 97.1 \\
\hline
\end{tabular}

Addition of bovine serum albumin did increase the amount of staphylocoagulase produced. The effect was most obvious after subculturing in nutrient broth using the chromogenic substrate method. An increase in positive reactions from 40 to 97 . 1\% was observed.

Staphylocoagulase production on brain heart infusion agar plates containing plasma showed that only 51 of the 70 5. aureus strains (72.9\%) gave positive reactions. In 11 strains, very weak or no staphylocoagulase reactions were observed. Moreover, interference by fibrinolysis took place with eight strains; thus, these strains also had to be scored as staphylocoagulase negative. Therefore, misjudging of the staphylocoagulase reaction in the latter strains cannot be excluded. Of the staphylocoagulase-negative control strains, S. epidermidis and S. haemolyticus were determined to be staphylocoagulase negative by all the test methods. $\underline{S}$. hyicus and $\mathrm{S}$. intermedius gave a positive reaction in the clotting 
assays, whereas when the strains were assayed by the chromogenic substrate method, positive reactions were not observed. It was demonstrated that $S$. hyicus produced a proteolytic enzyme, which may explain the falsepositive reaction in the clotting assays.

The additional 20 staphylococcal strains produced only trace amounts of staphylocoagulase in the clotting assays. However, in the chromogenic substrate assay, four strains gave a positive reaction which was not inhibited by $5 \mathrm{mM}$ ethylenediaminetetraacetic acid (EDTA). The additional positive deoxyribonuclease reaction indicated that these four strains could be identified as 5 . aureus.

Because false-positive reactions could have been caused by the presence of metalloproteases in the $\mathrm{S}$. aureus strains, the chromogenic substrate assay was performed also in the presence of $5 \mathrm{mM}$ EDTA, as described by Wegrzynowicz (20). For this assay, no influence of EDTA addition on the staphylocoagulase reaction could be demonstrated.

For routine use in a clinical laboratory, it is preferable to complete the identification within 1 day. Therefore, the cultivation time of the strains in brain heart infusion medium supplemented with $0.2 \%$ bovine serum albumin was reduced from 18 to $4 \mathrm{~h}$. In spite of lower staphylocoagulase activities (data not shown), 98.6\% of the chromogenic substrate assay tests still gave positive reactions.

\section{DISCUSSION}

Staphylocoagulase production has been established as one of the definitive characteristics of 5 . aureus (3). However, rapid identification of 5 . aureus has not always been possible because most assays may take $24 \mathrm{~h}$ to produce a positive result. In general, two tests can be performed: a tube test and a slide test. Although slide tests are performed in various laboratories, it must be emphasized that this assay involves the clumping factor and not staphylocoagulase activity ( 1 ).

The classic clotting methods were very reliable, as expected (Table $\mathbb{1}$ ). However, when the criteria of Sperber and Tatini (17) were strictly followed, a considerably lower number of positive reactions were recorded in the clotting assays because, for about $15 \%$ of the strains, no firm opaque clots were formed after $4 \mathrm{~h}$, awing to fibrinolysis and related reactions. For this 
reason, longer assay times should be avoided also (13). Therefore, misjudging of the reaction in the clotting assays can occur easily if one has no experience in this field.

The staphylocoagulase plate assay, which is in principle comparable to the method described by Van der Vijver et al. (19), and the quantitative radial slide assay method described by Kohl and Johnson (14) did not yield very reliable results. The relatively low numbers of positive staphylocoagulase reactions observed (72.9\%), were probably due to fibrinolysin or related enzymes produced by the $\mathrm{S}$. aureus strains. Kohl and Johnson might not have observed this interfering enzyme reaction because, in contrast to the strains used in this study, their test strains were from food rather than clinical sources.

Although false-negative and false-positive reactions in the clotting assays can be prevented by using a mixture of different protease inhibitors $(20,21)$, an assay based on a direct and specific measurement of staphylothrombin activity is preferred. From this study, it can be concluded that the chromogenic substrate assay is more reliable than the clotting assays. Even with the 20 weak staphylocoagulase-producing staphylococcal strains, staphylocoagulase could be demonstrated positively in four strains. The assay is specific, since 5 . intermedius and $\underline{S}$. hyicus will not give a positive result. Staphylocoagulase production by $S$. intermedius and $S$. hyicus, as reported by Hájek (8) and Devriese (5), needs further investigation.

Cultivation of the 5 . aureus strains in brain heart infusion medium supplemented with $0.2 \%$ bovine serum albumin and an assay time of $1 \mathrm{~h}$ resulted in a 98.6- to 100\%-positive score (Table 1). For routine assays, a cultivation time of $4 \mathrm{~h}$ enables a staphylocoagulase assay within 1 day. To eliminate possible false-positive reactions, we recommend adding $5 \mathrm{mM}$ EDTA to the assay mixture. PPSB can be abtained from almost every blood transfusion center at reasonable prices, especially in the case of outdated samples. Analyzing the data quantitatively, we could not observe a correlation between the amount of staphylocoagulase produced and phage type or origin of the $\underline{S}$. aureus strains. Also, there was no correlation between origin and phage type.

Nevertheless, this test enables a quantitative assay of staphylocoagulase and provides the means for setting up an epidemiological survey with large numbers of $\underline{S}$. aureus strains to investigate a possible relationship 
between the amount of staphylocoagulase produced and the virulence of $S$. aureus on the one hand and the role of the enzyme in the pathogenesis of 5 . aureus on the other. In addition, the availability of a simple quantitative method for the assay of staphylocoagulase makes it possible to monitor staphylocoagulase activities during enzyme purification. Since the assay can be performed in microtiter plates, high numbers of samples can be tested automatically.

In conclusion, the major advantages of this test are not only the short assay time but also the possibility of screening large numbers of strains or staphylocoagulase samples in a quantitative and specific way.

\section{ACKNOWLEDGEMENTS}

We are grateful to W.J. van Leeuwen for providing the Staphylococcus strains used. We thank E.E. Stobberingh for helpful discussions and for critically reading the manuscript.

\section{LITERATURE CITED}

1. Abramson, A. 1972. Staphylococcal enzymes, p. 187239. In J.0. Cohen (ed.), The staphylococci. John Wiley and Sons, Inc., New York.

2. Altenbern, R.A. 1966. On the nature of albuminpromoted coagulase release by Staphylococcus aureus. J. Infect. Dis. 116: 593-600.

3. Baird-Parker, A.C., L.R. Hill, W.E. K1oos, M. Koccur, P. Deding, and K.H. Schleifer. 1976. Appendix 1. Identification of staphylococci. Subcommittee on the Taxonomy of Staphylococci and Micrococci. Int. J. Syst. Bacteriol. 26: 333-334.

4. Blair, J.E., and R.E.0. Williams. 1961. Phage-typing of staphylococci. Bull. W.H.0. 24: 771-786.

5. Devriese, L.A. 1977. Isolation and identification of Staphylococcus hyicus. Am. J. Vet. Res. 3B: 787-792.

6. Engels, W., M. Kamps, and C.P.A. van Boven. 1978. Influence of cultivation conditions on the production of staphylocoagulase by 5 taphylococcus aureus 104. J. Gen. Microbiol. 109: $23 \overline{7-243}$. 
7. Engels, M., M.A.F. Kamps, and C.P.A. van Boven. 1980. Continuous culture studies on the production of staphylocoagulase by Staphylococcus aureus. Antonie van Leeuwenhoek J. Microbiol. Serol. 46: $533-548$.

8. Hájek, V. 1976. Staphylococcus intermedius, a new species isolated from animals. Int. J. Syst. Bacteriol. 26: 401-408.

9. Hazen, G.G., J.A. Hause, and J.A. Hubicki. 1965. An automated system for the quantitative determination of proteolytic enzymes using azocasein. Ann. N.Y. Acad. Sci. 130: 761-768.

10. Hemker, H.C., B.M. Bas, and A.D. Muller. 1975. Activation of a proenzyme by a stoichiometric reaction with another protein: the reaction between prothrombin and staphylocoagulase. Biochim. Biophys. Acta 379: 180-188.

11. Igarashi, H., T. Morita, and S. Iwanaga. 1979. A new method for purification of staphylocoagulase by a bovine prothrombin-sepharose column. J. Biochem. 86: 1615-1616.

12. Kloos, W.E., and K.H. Schleifer. 1975. Simplified scheme for routine identification of human Staphylococcus species. J. Clin. Microbiol. 1: 82-88.

13. Kloos, W.E., and P.B. Smith. 1980. Staphylococci, p. 83-87. In E.H. Lennette, A. Balows, W.J. Hausler, Jr., and J.P. Truant (ed.), Manual of clinical microbialagy. American Society for Microbiology, Washington, D.C.

14. Kohl, J.D., and M.G. Johnson. 1980. Quantitative, radial diffusion slide assay for staphylocoagulase. Appl. Environ. Microbiol. 39: 339-341.

15. Parisi, J.T., J.N. Baldwin, and M. Sottile. 1973. Pour plate method for the detection of coagulase production by Staphylococcus aureus. Appl. Microbiol. 25: 558-562.

16. Soulier, J.P., D. Ménaché, M. Steinbach, C. Blatrix, and F. Josso. 1969. Preparation and clinical use of P.P.S.B. (factors II, VII, $X$ and IX concentrate). Thrombos. Diath. Haemorrh. Suppl. 35: 61-69.

17. Sperber, W.H., and S.R. Tatini. 1975. Interpretation of the tube coagulase test for identification of Staphylococcus aureus. Appl. Microbiol. 29: 502-505.

18. Svendson, L., B. Blombäck, M. Blombäck, and P. olsson. 1972. Synthetic chromogenic substrates for determination of trypsin, thrombin and thrombin-like enzymes. Thrombos. Res. 1: 267-278. 
19. Van der Vijuer, J.C.M., C.A. Kraayeveld, and M.F. Michel. 1972. A solid medium for visual demonstration of coagulase production by Staphylococcus aureus. J. Clin. Pathol. 25: 450-452.

20. Wegrzynowicz, Z., P.B. Heckzo, G.R. Drapeau, J. Jeljaszewicz, and G. Pulverer. 1980. Prothrombin activation by a metalloprotease from Staphylococcus aureus. J. Clin. Microbiol. 12: 138-139.

21. Wegrzynowicz, Z., P.B. Heckzo, J.J. Jeljaszewicz, M. Neugebauer, and G. Pulverer. 1979. Pseudocoagulase activity of staphylococci. J. Clin. Microbiol. 9: 15-19.

22. Witt, I. 1977. Determination of plasma prothrombin with Chromozym TH, p. 155-169. In I. Witt (ed.), New methods for the analysis of coagulation using chromogenic substrates. W. de Gruyter, Berlin.

23. Zajdel, M., Z., Wegrzynowicz, J. Sawecka, J. Jeljaszewicz, and G. Pulverer. 1976. Mechanism of action of staphylocoagulase, p. 549-575. In J. Jeljaszewicz (ed.), Staphylococci and staphylococcal diseases. Fischer, Stuttgart, West Germany. 


\section{GENERAL DISCUSSION AND SIUMMARY}

Staphylococcus aureus is a commensal micro-organism of low virulence which usually causes severe infections only when the normal defences of the host are impaired. The acute inflammatory response and the activity of phagocytic cells are the most important defence mechanisms against staphylococcal infection. On the other hand, $S$. aureus has the disposal of a variety of virulence factors such as cell-wall components and extracellular proteins which can interfere strongly with the defence mechanisms of the host. Although our present knowledge of the interaction between antigenetic structure, opsonins and phagocytic cells has been enriched considerably by the work of Verbrugh and co-workers, the role of extracellular proteins in the pathogenesis of $\underline{S}$. aureus is still not well understood. It has to be noted that generally, studies concerning the virulence of $\underline{S}$. aureus have been greatly hampered by the lack of availability of an appropriate animal model. Not anly da relatively high doses of micro-organisms have to be applied but also the type of 5 . aureus strain, the route of administration and the animal species play an important role in the persistance of $S$. aureus during the infection process. Experimental staphylococcal infertions of the human skin pose great difficulties since a balance has to be found between a failure to produce any infection, and a spreading and severe infection, which is therefore unacceptable.

For these reasons, it was proposed by Musher to choose animals with an underlying disease or an impaired host defence mechanism as subjects for a study of the pathogenesis of 5 . aureus.

Although this approach might be successful, the number of variables in the infection process will be still considerable. An alternative model can be found probably in the assay system, described by Verhoef et al. This assay employs tritiated thymidine labeled staphylococci and permits a quantitative study of the separate steps of bacterial opsonization, attachment, ingestion and intracellular killing. In a similar model the physiological importance of exoproteins of $\underline{5}$. aureus could be investigated.

Since there is substantial evidence indicating that 
changes in the growth conditions of $S$. aureus induce major alterations in antigenic structure, production of exoproteins and biochemical properties of $\mathrm{S}$. aureus, due to phenotypical variations, it is progressively becoming recognized that the virulence of 5 . aureus varies according to the environment in which the staphylococci grow.

In the last decades much attention has been paid to the production and the characterization of the exoproteins of S. aureus. However, very little is known about the influence of growth conditions and medium composition on exoprotein production. Moreover, the regulation of the synthesis and the mechanisms of secretion of these exoproteins are generally obscure. One of the exoproteins produced by $\mathrm{S}$. aureus is staphylocoagulase. Although its precise role in the pathogenesis has not been established, staphylocoagulase is still considered as one of the most important virulence factors of pathogenic staphylococci. Furthermore, the ability of staphylococci to produce staphylocoagulase is a major criterion for the identification of $\mathrm{S}$. aureus.

In Chapter 1 , a review has been given of the mode of action of staphylocoagulase and its possible roles in the pathogenesis of 5 . aureus. Since the composition of the cell-wall and the production of exoproteins is strongly influenced by the growth environment of $S$. aureus, it was of interest to study several aspects of the production of staphylocoagulase in relation to the growth conditions.

The purpose of the investigations presented in this thesis was therefore to assess the influence of medium composition and growth conditions on the production of staphylocoagulase. Furthermore, the mechanism of secretion of this protein was studied by means of various inhibitors. 5pontaneaus staphylocoagulase-negative mutants were used to study their competitive ability towards their wild type strains and to elucidate the regulation of the synthesis of staphylocoagulase and of exoproteins in general. Because of the enormous capacity of 5 . aureus to vary phenotypically in response to changes in the growth environment, the majority of growth experiments were performed using a chemostat; in this way the micro-organisms could grow under steadystate conditions in a constant and reproducible environment.

In Chapter 2 the development of a defined growth medium is described in which high yields of staphylocoagulase were obtained from S. aureus strain 104. Besides a simple salts mixture, this medium contained glycerol, 
casein hydrolysate and three vitamins. This medium could replace the generally used Brain Heart Infusion medium and also facilitated the purification of staphylocoagulase since it was free of proteins and lipids. Casein hydrolysate could be substituted completely by a mixture of amino acids of an identical composition; removal of any of the amino acids from this mixture reduced the amount of staphylocoagulase. For practical reasons, casein hydrolysate was used in further experiments. It was demonstrated in batch cultures of $\mathrm{S}$. aureus that conditions of oxygen- and magnesium-limitation were required for optimal yields of staphylocoagulase. When the glycerol concentration was raised above $0.2 \%$ a considerable decrease in staphylocoagulase production took place, probably due to a decrease of the $\mathrm{pH}$ value of the culture. Therefore a practically constant $\mathrm{pH}$ (about 7.4) was another important factor in optimal staphylocoagulase production.

In Chapter 3, the production of staphylocoagulase was studied with continuous cultures of various $\mathrm{S}$. aureus strains in the newly developed medium. One of the rmajor problems in these studies was to minimize excessive foaming. Therefore, the baffles had to be removed from the culture vessel, the impeller speed kept at moderate values and air flushed over the surface. Particular attention was given to the type of antifoam to be used, since occasionally inhibitory effects on the staphylocoagulase production were observed. It was confirmed, that also in continuous culture, conditions of low axygen availability and magnesium-limitation were required for optimal staphylocoagulase production. The specific rate of the production of staphylocoagulase was dependent on the growth rate. In two bovine strains, the production rate pattern was similar to that of an inducible enzyme sensitive to catabolite repression, although no specific inducer or repressor could be demonstrated. The human strain 104 on the ather hand, produced staphylocoagulase constitutively. In all strains the specific rate of production of total extracellular protein was strictly proportional to the growth rate. These experiments clearly showed that the production of optimal amounts of staphylocoagulase was not always related to maximal production of biomass and total extracellular protein. Mannitol functioned as an energy source rather than as a carbon source because it was converted for a major part to acetate and for a minor part to lactate and not to new cell material. It could be demonstrated that the energy state of the cell is also of great importance in 
the regulation of staphylocoagulase production. Catabolite repression of staphylocoagulase production by mannitol was not observed in chemostat cultures of 5 . aureus whereas in batch cultures a considerably inhibition of the staphylocoagulase production by mannitol occurred, indicating that the inhibitory effects of carbohydrates on the production of staphylocoagulase in batch cultures are a consequence of the interaction of the organisms with their environment in a closed system. The bovine strains produced six times more staphylocoagulase in chemostat culture as compared with batch cultures of the same organism. This indicates that chemostat culture by virtue of its ability to provide constant and specific environmental conditions may prove to be a better culture technique for the production of staphy locoagulase.

A cell-bound staphylocoagulase could be detected in chemostat cultures of $\mathrm{S}$. aureus 104 under magnesium- and oxygen-limited growth conditions (Chapter 4). A distribution study revealed that $81 \%$ of this enzyme was membrane-bound and could be optimally released by Triton $x-100$. The remaining part was located in the periplasmic space and was released during protoplasting of the organism. The effects of cerulenin, quinacrine and lincomycin on the production of cell-bound and extracellular staphylocoagulase indicated that the hydrophobic cellbound form was a precursor in the production of extracellular staphylocoagulase. When magnesium was added to the medium in large excess of the growth requirement, both the production of extracellular staphylocoagulase and the production of cell-bound staphylocoagulase was strongly inhibited to the same extent. Since magnesium influences the membrane phospholipid composition (particularly the content of positively charged lipids) in Gram-positive bacteria, it was concluded that the negative effect of magnesium on the production of extracellular staphylocoagulase was due to a decreased membrane permeability towards cell-bound staphylocoagulase, resulting in a diminished secretion of the protein. The precise mechanism of the secretion of staphylocoagulase could not be established since no detailed characterization of the cell-bound staphylocoagulase was performed. The involvement of a lipid intermediate/exoprotein releasing protease system could not be excluded; however, the effects of cerulenin and quinacrine allowed also another interpretation since no effect of these substances on the production of total extracellular protein was observed. Therefore, before any conclusion 
can be drawn about the mechanism of the secretion system of staphylocoagulase and of exoproteins in general, a complete characterization of the cell-bound precursors and releasing protease(s) is essential, especially when signal-peptides are involved.

Cultivation of $S$. aureus strains 104 and NCTC 8178 in continuous culture gave rise to staphylocoagulasenegative cells which accumulated progressively by virtue of an apparent growth advantage of these staphylocoagulase-negative cells under the growth conditions used (Chapter 5). The loss of production of staphylocoagulase was accompanied by a simultaneous loss of the production of a-haemolysin and leucocidin. Characterization of the strains revealed no further differences in biotype, exoenzymes, phage pattern and plasmid content. From competition experiments cultures at different dilution rates and cultivation temperatures, it was concluded that the accumulation of staphylocoagulase-negative mutants is based on differences in affinity for the limiting substrates rather than on differences in the production rates of total extracellular protein. Moreover, it was demonstrated that the mode of regulation of the production of exoproteins in S. aureus is incompatible with the generally proposed models. In connection with evidence presented in the literature, it was concluded that the observed mutation in these $\underline{S}$. aureus strains was due probably to a transposable genetic element rather than to the loss of a plasmid or a prophage. Determination of the $L D_{50}$ value of these $S$. aureus strains by intracerebral injection into neonatal mice showed that the mutant strain of strain 104 was significantly less virulent than the parent strain whereas differences in virulence between parent and mutant of strain NCTC 8178 could not be demonstrated.

Chapter 6 describes a rapid and direct assay of staphylocoagulase for the routine identification of S. aureus. The assay is based on the limited proteolysis of the chromogenic substrate Chromozym TH by staphylothrombin. The great advantage of this method is that false-positive and false-negative reactions can be eliminated. A comparison of this method with three clotting assays has been made using recently isolated clinical strains of 5 . aureus. The new assay is specific, quantitative and easily automated. Therefore, it offers clinical laboratories a more reliable assay of staphylocoagulase and it enables an identification of $\underline{5}$. aureus within one day. Furthermore, this assay method can be applied excellently for the typing of 5 . aureus 
strains according to the eight different serotypes of staphylocoagulase, described by Dekio and Onimura.

The experiments described in this thesis demonstrate a close relationship between the production of staphylocoagulase by $S$. aureus and growth conditions. In addition, the secretion process of staphylocoagulase is influenced also by the growth environment. The data presented here are in accordance with present knowledge of the interaction between micro-organisms and their environment, and again demonstrate that the phenotypic variability of micro-organisms has far-reaching consequences for present-day research in medical microbiology. Therefore, data obtained with undefined cultures in undefined growth environments will have a very limited predictive value for the in vivo situation. Although the number of growth conditions studied in this thesis is limited, the results illustrate the importance of the growth environment on the production of staphylocoagulase by 5 . aureus. It is obvious that much more information is needed about the nature of the growth environment of $\mathrm{S}$. aureus during the infection process. When more data are available about the natural environment of 5. aureus which presumably will be severely nutrientlimited, a better insight can be obtained into the role of staphylocoagulase in the virulence and pathogenicity of this organism. It can be expected that investigations into these environmental parameters will provide a better strategy for the treatment and prevention of staphylococcal infections. 
Staphylococcus aureus is een commensaal micro-organisme met een lage virulentie. Het veroorzaakt alleen dan ernstige infecties wanneer de normale verdedigingsmechanismen van de gastheer zijn verminderd. De acute ontstekingsreactie en de activiteit van fagocyterende cellen vormen de belangrijkste verdediging tegen stafylococcen-infecties. Anderzijds beschikt $\underline{S \text {. aureus over }}$ een verscheidenheid van virulentie factoren zoals celwand componenten en extracellulaire eiwitten die sterk interfereren met de verdedigingsmechanismen van de gastheer. Hoewel gedurende de laatste jaren onze kennis ten aanzien van de interacties tussen antigene structuur, opsoninen en fagocyterende cellen aanzienlijk is toegenomen, is de rol van extracellulaire eiwitten in de pathogenese van $S$. aureus nog altijd onduidelijk. Eén van de belangrijkste redenen hiervoor is het ontbreken van een geschikt proefdiermodel.

Sedert inmiddels overtuigend is aangetoond dat veranderingen in de groei-omstandigheden van $\underline{S \text {. aureus }}$ belangrijke veranderingen induceren in antigene structuur, productie van exoeiwitten en biochemische eigenschappen van $S$. aureus, ten gevolge van fenotypische variabiliteit, wordt men zich steeds meer bewust van het

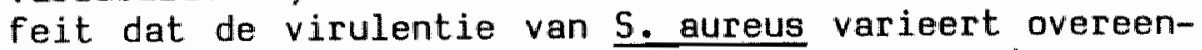
komstig het milieu waarin de stafylococcen groeien.

In de afgelopen decennia is veel aandacht geschonken aan de productie en karakterisering van exoeiwitten van 5. aureus. Er is echter weinig bekend over de invloed van de groei-condities en medium-samenstelling op de productie van deze exoeiwitten. Bovendien is het in het algemeen onduidelijk hoe de regulatie van de synthese en het uitscheidingsmechanisme van exoeiwitten plaats vindt. Eén van de exoeiwitten, gepraduceerd door $\frac{S}{d e}$ aureus, is stafylocoagulase. Alhoewel een rol in de pathogenese niet is vastgesteld, wordt stafylocoagulase nog steeds beschouwd als één van de belangrijkste virulentie factoren van pathogene stafylococcen. Anderzijds is het stafylocoagulase-producerend vermogen van stafylococcen een belangrijk criterium voor de identificatie van $\mathrm{S}$. aureus.

In Hoofdstuk 1 wordt een overzicht gegeven over het werkingsmechanisme van stafylocoagulase en de mogelijke rollen in de pathogenese van $\underline{5}$. aureus. Omdat de samenstelling van de celwand en de productie van exoeiwitten sterk wordt beinvloed door de groei-omstandigheden van S. aureus, was het interessant diverse aspecten van de 
roersnelheid terug te brengen tot lagere waarden en lucht over het cultuur-oppervlak te leiden in plaats van door de cultuur. Bijzondere aandacht werd geschonken aan het type antischuim-middel dat moest worden gebruikt andat geregeld remmende effecten hiervan op de stafylocoagulase productie werden waargenomen. Ook onder continue cultuur omstandigheden bleek een lage beschikbaarheid van zuurstof en een magnesium-limitatie een vereiste voor optimale stafylocoagulase productie. De specifieke productie-snelheid van stafylocoagulase was sterk afhankelijk van de groeisnelheid. In twee runderstammen was het productiepatroon identiek aan dat van een induceerbaar enzym, gevoelig voor kataboliet repressie, hoewel geen specifieke inductor of repressor kon worden aangetoond. Anderzijds produceerde de humane stam 104 stafylocoagulase constitutief. In alle stammen was de specifieke productie-snelheid van totaal extracellulair eiwit strikt evenredig met de groeisnelheid. Deze experimenten lieten duidelijk zien dat de productie van optimale hoeveelheden stafylocoagulase niet altijd gekoppeld was aan een maximale productie van biomassa en tataal extracellulair eiwit. Mannitol functioneerde meer als energiebron dan als koolstofbron omdat het grotendeels werd omgezet in acetaat en voor een klein gedeelte in lactaat, en niet in nieuw celmateriaal. Dok de energie status van de cel bleek van groot belang voor de regulatie van de stafylocoagulase productie. Kataboliet repressie van de stafylocoagulase productie door mannitol werd niet wargenomen in chemostaat culturen van 5 . aureus terwijl in batch culturen een aanzienlijke remming van de stafylocoagulase productie door mannitol optrad. Dit wijst erop dat de remmende effecten van koolhydraten op de productie van stafylocoagulase in batch culturen het gevolg waren van een interactie van de organismen met hun omgeving in een gesloten systeem. De runderstammen produceerden zes keer zoveel stafylocaagulase in chemostaat culturen dan in batch culturen van hetzelfde organisme. Dit geeft aan dat chemostaat culturen, door hun eigenschap constante en specifieke milieuomstandigheden te creëren, een betere kweektechniek kunnen zijn voor de productie van stafylocoagulase.

Een cel-gebonden stafylocoagulase kon worden aangetoond in chemostaat culturen van S. aureus 104 onder magnesium- en zuurstof-beperkende groei-omstandigheden. Een verdelingsstudie toonde aan dat $B 1 \%$ van dit enzym membraan-gebonden was en optimaal kon worden vrijgemaakt met behulp van Triton $X-100$. Het resterend gedeelte was gelocaliseerd in de periplasmatische ruimte en kwam vrij 
praductie van stafylacoagulase te bestuderen in relatie tot de groei-omstandigheden.

Het doel van het onderzoek, beschreven in dit proefschrift, was daarom na te gaan welke de invloed is van medium-samenstelling en groei-omstandigheden op de productie van stafylocoagulase. Bovendien werd het uitscheidingsmechanisme van stafylocoagulase bestudeerd met behulp van diverse remers. Spontane stafylocoagulasenegatieve mutanten werden gebruikt om hun competitief vermogen ten opzichte van de wilde stammen te bestuderen en de regulatie van de synthese op te helderen van stafylocoagulase en van exoeiwitten in het algemeen. Omdat S. aureus een zeer groot vermogen bezit om fenotypisch te variëren als reactie op veranderingen in het milieu, werd het merendeel der groei-experimenten uitgevoerd in een chemostaat (continue cultuur); op deze wijze konden de micro-organismen groeien in een dynamisch evenwicht in een constant en reproduceerbaar milieu.

In Hoofdstuk 2 wordt de ontwikkeling van een gedefinieerd kweekmedium beschreven waarin hoge opbrengsten van stafylocoagulase, geproduceerd door $\underline{5}$. aureus stam 104, werden verkregen. Dit medium bevatte een mengsel van minerale zouten, glycerol, caseine hydrolysaat en drie vitamines. Het bleek dat dit medium het veel gebruikte Brain Heart Infusion medium geheel kon vervangen; de zuivering van stafylocoagulase werd hierdoor vergemakkelijkt omdat het nieuwe medium geen eiwitten en lipiden bevatte. Het caseine hydrolysaat kon op zijn beurt geheel worden vervangen door een mengsel van aminozuren in een identieke samenstelling; wanneer echter één van de aminozuren in dit mengsel werd weggelaten, verminderde de opbrengst aan stafylocoagulase. Uit praktische overwegingen werd het caseine hydrolysaat gebruikt in de overige experimenten. In zogenaamde batch culturen van 5 . aureus bleek dat kweekomstandigheden, warin zuurstof en magnesium beperkend waren, vereist waren voor een optimale stafylocoagulase productie. Glycerol concentraties hoger dan $0,2 \%$ remden de stafylocoagulase productie sterk, waarschijnlijk door een daling van de $p H$ van de cultuur. Daarom was een nagenoeg constante $\mathrm{pH}$ (ongeveer 7,4 ) een andere belangrijke factor voor een optimale productie van stafylocoagulase.

In Hoofdstuk 3 werd de productie van stafylocoagulase bestudeerd in continue culturen van diverse 5. aureus stammen in het nieuw ontwikkelde medium. Eén van de belangrijkste problemen in deze studies was het verminderen van overmatige schuimvorming. Daarom was het nodig de keerschotten te verwijderen uit het kweekvat, de 
tijdens de bereiding van protoplasten van het organisme. De effecten van cerulenine, quinacrine en lincomycine op de productie van cel-gebonden en extracellulair stafylocoagulase gaven aan dat de hydrofobe cel-gebonden vorm een precursor was in de productie van extracellulair stafylocoagulase. Indien magnesium in overmaat aan het medium werd toegevoegd, werd de productie van cel-gebonden en extracellulair stafylocoagulase in gelijke mate sterk gerend. Omdat magnesium de fosfolipide samenstelling (met name het gehalte aan positief geladen lipiden) van de membraan in gram-positieve bacteriën beinvioedt, werd geconcludeerd dat het negatieve effect van magnesium op de productie van extracellulair stafylocoagulase werd veroorzaakt door een afname in de membraan permeabiliteit voor cel-gebonden stafylocoagulase zodat de uitscheiding van het eiwit werd verminderd. Het juiste uitscheidingsmechanisme van stafylocoagulase kon niet worden vastgesteld ondat geen gedetailleerde karakterisering van het cel-gebonden stafylocoagulase werd uitgevoerd. De rol van een lipid intermediair/exoeiwit vrijmakend protease systeem kon niet worden uitgesloten hoewel de effecten van cerulenine en quinacrine ook op een andere manier konden worden geinterpreteerd, mede gezien het feit dat geen van deze verbindingen een invloed hadden op de productie van totaal extracellulair eiwit. Voordat enige conclusie omtrent het uitscheidingsmechanisme van stafylocoagulase en dat van exoeiwitten in het algemeen kan worden getrokken, is een complete karakterisering van de cel-gebonden precursors noodzakelijk, vooral wanneer ook nog signaal-peptiden in dit proces zijn betrokken.

Tijdens het kweken van 5. aureus stam 104 en stam NCTC 8178 in continue cultuur, verschenen stafylocoagulase-negatieve cellen die konden worden wargenomen ten gevolge van een groei-voordeel van deze stafylocoagulase-negatieve cellen onder de gebruikte kweekomstandigheden (Hoofdstuk 5). Het verlies van stafylocoagulase productie ging gepaard met een gelijktijdig verlies van de productie van $\alpha$-haemolysine en leucocidine. Een karakterisering van deze stammen liet zien dat er geen verdere verschillen waren in biotype, exoenzymen, faggatroon en plasmid-gehalte. Uit competitie experimenten bij verschillende verdunnings-snelheden en kweektemperaturen, werd geconcludeerd dat de ophoping van de stafylocoagulase-negatieve mutanten het gevolg was van verschillen in affiniteit voor de groei-beperkende substraten en niet het gevolg van verschillen in de productie-snelheid van totaal extracellulair eiwit. 
Bovendien werd vastgesteld dat de regulatie van de productie van exoeiwitten onverenigbaar was met de algemeen voorgestelde modellen. Met behulp van literatuurgegevens werd geconcludeerd dat de opgetreden mutatie in deze S.aureus stammen vermoedelijk werd veroorzaakt door een transposon en niet door het verlies van een plasmid of een profaag. Bepaling van de $L D_{50}$ waarde van de $S$. aureus stammen door middel van intracerebrale injectie in neonatale muizen liet zien dat de mutant van stam 104 significant minder virulent was dan de wilde stam terwijl geen verschillen in virulentie tussen de wilde stam en de mutant van stam NCTC 8178 waren aan te tonen.

Hoofdstuk 6 beschrijft een snelle en directe bepalingsmethode van stafylocoagulase ten behoeve van de routine identificatie van $\mathrm{S}$. aureus. De bepalingsmethode is gebaseerd op een beperkte proteolyse van het chromogene substraat Chromozym TH door stafylothrombine. Het grote voordeel van deze methode is dat vals-positieve en -negatieve reacties kunnen worden geélimineerd. Een vergelijking van deze methode met drie stollingsmethoden werd gemaakt door gebruik te maken van recent geisoleerde $\mathrm{klinische} \mathrm{S}$. aureus stammen. De nieuwe methode is specifiek, kwantitatief en gemakkelijk te automatiseren. Daarom biedt deze methode het klinisch laboratorium een betrouwbare bepalingsmethode van stafylocoagulase en het. maakt een identificatie van $\underline{S}$. aureus binnen één dag mogelijk. Bovendien is de methode uitstekend te gebruiken voor het typeren van $\mathbf{S}$. aureus stammen volgens de acht verschillende serotypen van stafylocoagulase zoals beschreven door Dekio en Onimura.

De experimenten beschreven in dit proefschrift laten zien dat er een nauwe relatie bestaat tussen de productie van stafylocoagulase door $\mathrm{S}$. aureus en de groeiomstandigheden. Bovendien wordt ook het uitscheidingsproces van stafylocoagulase beinvloed door het milieu. De weergegeven resultaten zijn in overeenstemming met de huidige kennis over de wisselwerking tussen micro-organismen en hun milieu en laten zien dat de fenotypische variabiliteit van micro-organismen verstrekkende gevolgen heeft voor het onderzoek op het gebied van de medische microbiologie heden ten dage. Daarom hebben gegevens, verkregen met ongedefinieerde culturen in ongedefinieerde groei-omstandigheden, een zeer beperkte voorspellende waarde voor de situatie in vivo. Hoewel het aantal groei-omstandigheden, onderzocht in dit proefschrift beperkt was, illustreren de resultaten het belang van het milieu op de productie van stafylocoagulase door 5 . aureus. Het is duidelijk dat veel meer 
gegevens nodig zijn over de aard van de groei-omstandigheden van 5 . aureus tijdens het infectie-proces. Wanneer meer feitenmateriaal beschikbaar is over het natuurlijke millieu van $S$. aureus, dat ongetwijfeld sterk nutrientbeperkend zal zijn, kan een beter inzicht worden verkregen in de rol van stafylocoagulase in de virulentie en pathogeniteit van dit organisme. Het is te verwachten dat onderzoek naar deze millieu parameters een betere strategie zullen verschaffen voor de behandeling en voorkoming van stafylococcen infecties. 


\section{CURRICULUM VITAE}

De schrijver van dit proefschrift werd geboren op 11 november 1946 te Helmond. Het eindexamen HBS-B werd behaald in 1964 aan het Comenius-lyceum te Amsterdam. Daarna volgde hij de studie in de scheikunde aan de Gemeente Universiteit te Amsterdam, waarbij hij in 1971 het doctoraal examen biochemie aflegde. Aansluitend vervulde hij de militaire dienstplicht, waarbij hij werd geplaatst bij de afdeling Bacteriologie van het Rijks Instituut voor de Volksgezondheid (RIV) te Bilthoven. Van 1973-1975 was hij als wetenschappelijk medewerker verbonden aan het laboratorium voor Medische Microbiologie van de Erasmus Universiteit te Rotterdam. Sinds 1975 is de auteur als wetenschappelijk medewerker verbonden aan de capaciteitsgroep Medische Microbiologie van de Rijksuniversiteit Limburg te Maastricht. Onder leiding van Prof.Dr. C.P.A. van Boven werd het onderzoek verricht, hetwelk geleid heeft tot de bewerking van dit proefschrift. 